\title{
Flora da Bahia: Begoniaceae
}

\section{Bernarda de Souza Gregório ${ }^{1 *}$, Jorge Antonio Silva Costa ${ }^{2, a}$ \& Alessandro Rapini ${ }^{1, b}$}

${ }^{1}$ Programa de Pós-Graduação em Botânica, Universidade Estadual de Feira de Santana, Feira de Santana, Bahia, Brasil.

${ }^{2}$ Centro de Formação em Ciências Ambientais, Instituto Sosígenes Costa de Humanidades, Artes e Ciências, Universidade Federal do Sul da Bahia, Porto Seguro, Bahia, Brasil.

Resumo - É apresentado o tratamento taxonômico da família Begoniaceae para o estado da Bahia. São reconhecidas 38 espécies, 15 endêmicas e quatro descritas originalmente a partir deste estudo. A maior parte das espécies ocorre na Mata Atlântica (32 espécies), seguida pela Caatinga (11 espécies) e Cerrado (uma espécie). Nove nomes são tratados aqui pela primeira vez como sinônimos. São apresentadas descrições, chave de identificação, dados fenológicos, ilustrações, mapas de distribuição geográfica na Bahia e comentários.

Palavras-chave adicionais: Begonia, endemismo, florística, Nordeste, taxonomia.

Abstract (Flora of Bahia: Begoniaceae) - The taxonomic treatment of the Begoniaceae from Bahia state is presented. We recognize 38 species, 15 are endemic and four were firstly described based on this study. Most of the species occur in the Atlantic Forest (32 species), followed by the Caatinga (11 species) and Cerrado (one species). Nine names are treated as synonym for the first time here. Descriptions, identification key, phenological data, illustrations, maps of geographical distribution in Bahia and comments are presented.

Additional key words: Begonia, endemism, floristics, Northeast Brazil, taxonomy.

\section{BEGONIACEAE}

Ervas, trepadeiras, subarbustos, menos frequentemente arbustos (geralmente carnosos): terrestres, epífitas ou hemiepífitas. Caule com nós bem marcados e entrenós de tamanho variável. Estípulas geralmente grandes, persistentes ou caducas. Folhas alternas, simples, raramente compostas, inteiras, lobadas, partidas ou sectas, frequentemente assimétricas, basifixas ou peltadas, actinódromas ou craspedódromas. Inflorescências cimosas, raramente tirsoides, axilares ou terminais, uni ou bissexuadas, paucifloras ou multifloras. Flores diclinas, tépalas petaloides, livres ou conatas, alvas, róseas, vermelhas ou raramente amarelas ou laranja; flores estaminadas com 2 ou 4 ( 8 ou 10) tépalas, actinomorfas, prefloração valvar; estames geralmente numerosos, amarelos, filetes livres ou unidos na base, anteras rimosas ou poricidas; flores pistiladas com $2-5(-10)$ tépalas, geralmente assimétricas, prefloração imbricada; gineceu com (2)3(-6) carpelos; ovário ínfero (Begonia L.) ou semi-ínfero (Hillebrandia Oliv.), (1-)3(-8) lóculos; placentação axilar ou parietal, placenta inteira ou partida; estiletes geralmente bífidos, com número igual ao de carpelos, ramos espiralados ou não, superfície estigmática papilosa. Frutos geralmente cápsulas loculicidas, (0-)3(4-7) alas, iguais ou não. Sementes pequenas, numerosas, com colar de células alongadas na região micrópilo-hilar.

\footnotetext{
*Autora para correspondência: bernardasogreg@hotmail.com; ajcosta.bio@gmail.com; brapinibot@yahoo.com.br Editor responsável: Pedro Fiaschi

Submetido: 27 maio 2016; aceito: 19 jul. 2016

Publicação eletrônica: 2 out. 2016; versão final: 10 out. 2016
}

Begoniaceae possui distribuição pantropical e aproximadamente 1.500 espécies, agrupadas em dois gêneros (Neale et al. 2006). O gênero Hillebrandia, do arquipélago do Havaí, é monoespecífico ( $H$. sandwicensis Oliv.), enquanto Begonia possui ampla distribuição nas regiões tropicais e subtropicais. A Região Neotropical e a Ásia são os centros de diversidade da família, que ocorre preferencialmente em ambientes florestais sombreados, com elevados índices higrométricos (Clement et al. 2004).

\section{Begonia L.}

Caule carnoso, ereto, escandente, prostrado ou decumbente. Folhas basifixas, menos frequentemente peltadas. Flores estaminadas com 2 ou 4 tépalas, em dois verticilos, sendo dois pares externos maiores e dois internos menores; flores pistiladas frequentemente com 5 tépalas. Ovário com placentação axial.

Begonia é um dos maiores gêneros de angiospermas, possuindo grande número de microendemismos e híbridos (Clement et al. 2004; Neale et al. 2006; Goodall-Copestake et al. 2009). Algumas espécies são muito utilizadas na ornamentação de interiores (Souza \& Lorenzi 2008), na medicina (Ramesh et al. 2002; Wu et al. 2004; Pandikumar et al. 2009) e como biondicadoras de ambientes florestais preservados (Duarte 1961). No Brasil, está representado por 213 espécies, 186 endêmicas (Jacques 2015) e 27 raras (Jacques 2009), distribuídas em todas as fitofisionomias, com exceção dos manguezais (Jacques \& Mamede 2005), sendo a Mata Atlântica o centro de diversidade do gênero no Brasil (Duarte 1961; Jacques \& Mamede 2004). 


\section{Chave para as espécies}

1. Lâminas foliares com venação craspedódroma ou semicraspedódroma.

2. Trepadeiras.

3. Estípulas lanceoladas; lâminas foliares com margem serreada; cápsulas $0,6-1,2 \times 0,5-1,2 \mathrm{~cm}$, com alas iguais

3'. Estípulas ovadas; lâminas foliares com margem inteira a esparsamente denteada; cápsulas 6-8 8 15,5$19 \mathrm{~mm}$, com alas desiguais

2'. Ervas, arbustos ou subarbustos.

4. Folhas com pecíolo pubescente a tomentoso e lâmina com base arredondada a obtusa; cápsulas com a ala maior $\leq 4 \mathrm{~mm}$ larg.

30. B. ruhlandiana

4'. Folhas com pecíolo glabriúsculo, com tricomas glandulares microscópicos a glabro ou seríceo e lâmina com base oblíqua; cápsulas com a ala maior $\geq 5 \mathrm{~mm}$ larg.

5. Lâminas foliares com margem inteira plana a levemente ondulada.

6. Estípulas persistentes; cimeiras com 4-8 flores, 2 ou 3 nós; cápsulas 1,8-2 cm compr.

8. B. elianeae

6'. Estípulas caducas; cimeiras com 40-60 flores, 4-6 nós; cápsulas 0,7-1,5 cm compr.

3. B. besleriifolia

5'. Lâminas foliares com margem serreada a serrilhada, crenado-dentada ou irregularmente serrilhada.

7. Folhas com pecíolo piloso, sem tricomas glandulares microscópicos, e lâmina pilosa em ambas as faces; flores com tépalas pilosas na face abaxial

37. B. ulmifolia

7'. Folhas com pecíolo glabriúsculo, com tricomas glandulares microscópicos, e lâmina glabra em ambas as faces; flores com tépalas glabras ou apenas com tricomas glandulares microscópicos na face abaxial

32. B. saxicola

1'. Lâminas foliares com venação actinódroma.

8. Trepadeiras.

9. Flores estaminadas e pistiladas com tépalas vermelhas; anteras poricidas

28. B. radicans

9'. Flores estaminadas e pistiladas com tépalas brancas; anteras rimosas.

10. Lâminas foliares com margem serrilhada

10. B. fagifolia

10'. Lâminas foliares com margem irregularmente crenada a denticulada ou crenada a irregularmente denteada.

11. Lâminas foliares arredondadas a transversalmente elípticas

4. B. convolvulacea

11'. Lâminas foliares obovadas, ovadas ou elípticas.

12. Plantas pilosas

9. B. epibaterium

12'. Plantas glabriúsculas a glabras

14. B. glabra

8'. Ervas, arbustos ou subarbustos.

13. Lâminas foliares digitadas

13'. Lâminas foliares subinteiras, inteiras, levemente lobadas ou lobadas.

14. Cápsulas com 4 ou 5 alas

7. B. digitata

14'. Cápsulas com 3 alas.

15. Pecíolos com colar de tricomas ou escamas no ápice.

16. Plantas vilosas a glabrescentes; entrenós $1-3 \mathrm{~mm}$ compr.; estípulas 7-8 $\times 3-4 \mathrm{~mm}$; lâminas foliares com ápice arredondado

6. B. delicata

16. Plantas glabriúsculas; entrenós $0,5-6,5 \mathrm{~cm}$ compr.; estípulas $0,5-2,5(-3,5) \times 2-9(-12)$ $\mathrm{mm}$; lâminas foliares com ápice acuminado

21. B. neglecta

15'. Pecíolos sem colar de tricomas ou escamas no ápice.

17. Plantas com caule ereto.

18. Lâminas foliares peltadas.

19. Plantas lanuginosas; lâminas foliares com ápice obtuso; flores estaminadas com 4 tépalas

15. B. goldingiana

19'. Plantas glabriúsculas a glabras; lâminas foliares com ápice arredondado; flores estaminadas com 2 tépalas

18'. Lâminas foliares basifixas.

20. Plantas com tricomas estrelados.

21. Estípulas triangulares; cápsulas com alas desiguais (ala maior 3-6 mm larg., alas menores 1-4 mm larg.)

16. B. grisea

21'. Estípulas lanceoladas; cápsulas com alas iguais (alas 1,5-4 mm larg.) ....

23. B. obdeltata

20'. Plantas com tricomas simples, finos, de base espessa, dendríticos ou glandulares microscópicos, mas nunca tricomas estrelados. 
22. Estípulas reflexas

22'. Estípulas apressas.

23. Lâminas foliares com base oblíqua.

24. Lâminas foliares oblongas a obovadas, com ápice acuminado; estípulas com ápice apiculado e margem inteira, plana a levemente ondulada; cápsulas com alas iguais (3-7 mm larg.) a desiguais (ala maior 4-9 mm larg., alas menores 3-4,5 mm larg.)

2. B. bahiensis

24'. Lâminas foliares ovadas a largamente ovadas, com ápice obtuso a arredondado; estípulas com ápice arredondado e margem ciliada a denticulada; cápsulas com alas desiguais (ala maior 1,2-1,7 cm larg., alas menores 3-5 mm larg.)

5. B. cucullata

23'. Lâminas foliares com base cordada.

25. Estípulas com margem fimbriada; flores pistiladas com 3 bractéolas.

26. Estípulas lanceoladas; sementes fusiformes 12. B. fischeri

26'. Estípulas ovadas a elípticas; sementes oblongas

17. B. hirtella

25'. Estípulas com margem inteira; flores pistiladas com 2 bractéolas.

27. Lâminas foliares elípticas a obovadas .... 36. B. sylvatica

27'. Lâminas foliares transversalmente elípticas.

28. Estípulas venosas; cápsulas com alas iguais e inconspícuas 19. B. lossiae

28'. Estípulas não venosas; cápsulas com alas desiguais e conspícuas.

29. Plantas pubescentes, tricomas dendríticos presentes; lâminas foliares com recortes profundos, atingindo a metade da distância entre a margem e a nervura central

24. B. paganuccii

29'. Plantas glabriúsculas a pilosas, tricomas dendríticos ausentes; lâminas foliares com recortes superficiais, não atingindo a metade da distância entre a margem e a nervura central 29. B. reniformis

17. Plantas com caule prostrado ou decumbente.

30. Lâminas foliares peltadas

30'. Lâminas foliares basifixas.

11. B. fellereriana

31. Lâminas foliares buladas

22. B. neocomensium

31'. Lâminas foliares não buladas.

32. Plantas lanosas; flores pistiladas com bractéolas linear-triangulares

26. B. pinheironis

32'. Plantas hirsutas, pubescentes, pilosas, tomentosas, glabriúsculas, pubescentes a tomentosas ou pilosas a tomentosas; flores pistiladas com bractéolas estreitamente triangulares, estreitamente elípticas a oblongas, lanceoladas ou oblanceoladas.

33. Plantas com tricomas estrelados

25. B. pernambucensis

33'. Plantas com tricomas simples, finos, de base espessa ou tricomas glandulares microscópicos, mas nunca tricomas estrelados.

34. Lâminas foliares ovadas

33. B. saxifraga

34'. Lâminas foliares arredondadas a transversalmente elípticas.

35. Lâminas foliares com margem denticulada; tépalas externas das flores estaminadas ovadas a elípticas

18. B. itaguassuensis

35'. Lâminas foliares com margem crenada ou crenulada; tépalas externas das flores estaminadas orbiculares a largamente ovadas. 
36. Plantas glabriúsculas; brácteas de primeira ordem estreitamente triangulares ........ 20. B. mattos-silvae

36'. Plantas pilosas a tomentosas; brácteas de primeira ordem ovadas ou lanceoladas.

37. Brácteas de primeira ordem ovadas, 2,5-7 $\times$ 1,5-4 mm; estames 6-10 …31. B. russelliana

37'. Brácteas de primeira ordem lanceoladas, 1-1,5 $\times 0,4-0,7 \mathrm{~mm}$; estames $28-32$

35. B. subacida

1. Begonia angularis Raddi, Mem. Mat. Fis. Soc. Ital. Sci. Modena, Pt. Mem. Fis. 18: 407. 1820.

Figuras $1 \mathrm{~A}-\mathrm{E}$ e 2.

Ervas ou subarbustos, 0,6-1,7 m alt., glabriúsculos, esparsos tricomas simples e glandulares microscópicos. Caule ereto, glabriúsculo; entrenós 2,5-5,6 cm compr. Estípulas $1,5-2,8 \times 0,7-2,2 \mathrm{~cm}$, ovadas, ápice mucronulado, margem inteira, carenadas, reflexas, persistentes. Folhas com pecíolo 4,6-12,5 cm compr., com esparsos tricomas glandulares; lâmina 12,5-28,5 × 6-12,3 cm, inteira, assimétrica, basifixa, papirácea, lanceolada a elíptica, ápice acuminado, base cordada, margem crenada, ciliada, glabra em ambas as faces; face adaxial verde, face abaxial verde-clara a vinácea; venação actinódroma, 6-8 nervuras na base. Cimeiras 12-26 cm compr., 10-70 flores, 4-7 nós; brácteas de primeira ordem ca. $3 \times 1,5 \mathrm{~mm}$, triangulares, caducas. Flores estaminadas sem bractéolas; tépalas 4 , alvas, as externas maiores, ovadas, côncavas, face abaxial com esparsos tricomas glandulares a glabras, as internas oblanceoladas, face abaxial glabra; estames 10-18, anteras rimosas, conectivos proeminentes. Flores pistiladas com 2 bractéolas deltoides, persistentes; tépalas 5, alvas, sendo uma ligeiramente maior, elípticas a obovadas, face abaxial glabra; ovário com placenta inteira. Cápsulas $0,8-1,3 \times 1,8-2,7 \mathrm{~cm}$, com tricomas glandulares microscópicos a glabras; alas 3 , desiguais, a maior $1,2-1,7 \mathrm{~cm}$ larg., ápice obtuso a agudo, as menores $2-5 \mathrm{~mm}$ larg., arredondadas a agudas. Sementes oblongas.

Endêmica do Brasil, ocorre nos estados da Bahia, Espírito Santo, Minas Gerais, Paraná, Rio de Janeiro e São Paulo (Jacques 2015). E8, F8: Floresta ombrófila densa montana e submontana. Habita áreas preservadas ou perturbadas, com solos arenosos ou sobre rochas, nas margens de rios. Floresce em julho e outubro, e foi coletada com frutos em maio, outubro e novembro.

Material selecionado - Amargosa, Serra do Timbó, fazenda do Sr. Arlindo, 1301'49"S, 39³6'17"W, 16 nov. 2007 (bot., fl., fr.), F.M. Ferreira et al. 1830 (CEPEC); Jaguaquara, Distrito de Baixão de Ipiuna, 13040'05'S, 3948'57"W, 685 m s.n.m., 9 out. 2012 (fl., fr.), D.C. Zappi et al. 3378 (RB); Wenceslau Guimarães, Estação Ecológica Estadual Wenceslau Guimarães, trilha da Petioba 1334'49"S, 3942'17"W, 24 maio 2013 (fr.), B.S. Gregório 253 (HUEFS).

Material adicional - BRASIL. RIO DE JANEIRO: s.d. (fl. fr.), A.C.V. Schott 4639 (tipo de B. angularis: B [foto]).

Begonia angularis possui uma característica exclusiva dentre as espécies que ocorrem na Bahia, que são as estípulas reflexas. Os indivíduos analisados do
Estado possuem a ala maior da cápsula um pouco mais desenvolvida que a média observada nos demais estados, e os estiletes variam em número de três ou quatro. No caso de quatro estiletes, o quarto é geralmente pouco desenvolvido e o número de lóculos não varia, permanecendo três. Os estiletes podem apresentar um dos ramos pouco desenvolvido, bem como pode ocorrer a fusão de um estilete pouco desenvolvido a outro de tamanho normal. Assemelhase a $B$. sylvatica pelo tipo de hábito e aspecto geral da morfologia foliar; no entanto, é facilmente diferenciada pelas estípulas reflexas (vs. apressas em B. sylvatica), margem das lâminas foliares crenada (vs. irregularmente crenado-serrilhada) e flores pistiladas com uma das tépalas maior (vs. três tépalas maiores).

2. Begonia bahiensis A.DC., Ann. Sci. Nat., Bot., sér. 4, 11: 137. 1859.

$=$ Begonia bidentata var. insularum A.DC. in Martius, Fl. Bras. 4(1): 381; tab. 99, fig. 2. 1861. Syn. nov.

Figuras $1 \mathrm{~F}-\mathrm{K}$ e 2.

Ervas ou subarbustos, $20-60 \mathrm{~cm}$ alt., glabriúsculos a glabros, tricomas simples, finos, tricomas de base espessa e glandulares microscópicos. Caule ereto, glabriúsculo; entrenós 1-7,5 cm compr. Estípulas 0,8-2 $\times 0,3-1 \mathrm{~cm}$, ovadas a lanceoladas, ápice apiculado, margem inteira a levemente ondulada, carenadas, apressas, persistentes. Folhas com pecíolo $0,8-6,5 \mathrm{~cm}$ compr., glabriúsculo; lâmina 5-15,5(-21) × 2-7(-9) cm, inteira, assimétrica, basifixa, papirácea, oblonga a obovada, ápice acuminado, base oblíqua, margem serrilhada a irregularmente crenado-denticulada, ciliada, glabrescente em ambas as faces; face adaxial verde, face abaxial verde-clara a vinácea; venação actinódroma, (3) 4 ou 5 nervuras na base. Cimeiras 5,5-8,5(-14) cm compr., 4-20 flores, 2 ou 3 nós; brácteas de primeira ordem $2-4 \times 0,5-1 \mathrm{~mm}$, lanceoladas, persistentes. Flores estaminadas sem bractéolas; tépalas 4 , alvas a róseas, as externas maiores, ovadas, face abaxial com esparsos tricomas glandulares a glabra, as internas oblanceoladas, face abaxial glabra; estames 16-28, anteras rimosas, conectivos proeminentes. Flores pistiladas com 2 bractéolas lanceoladas, persistentes; tépalas 5 , alvas a róseas, sendo três maiores, elípticas a ovadas, face abaxial glabra; ovário com placenta inteira. Cápsulas 1,1-1,7 × 1,3-1,5 cm, com esparsos tricomas glandulares microscópicos; alas 3 , iguais a desiguais, a maior 4-9 mm larg., ápice arredondado, as menores 34,5 mm larg., arredondadas. Sementes oblongas. 


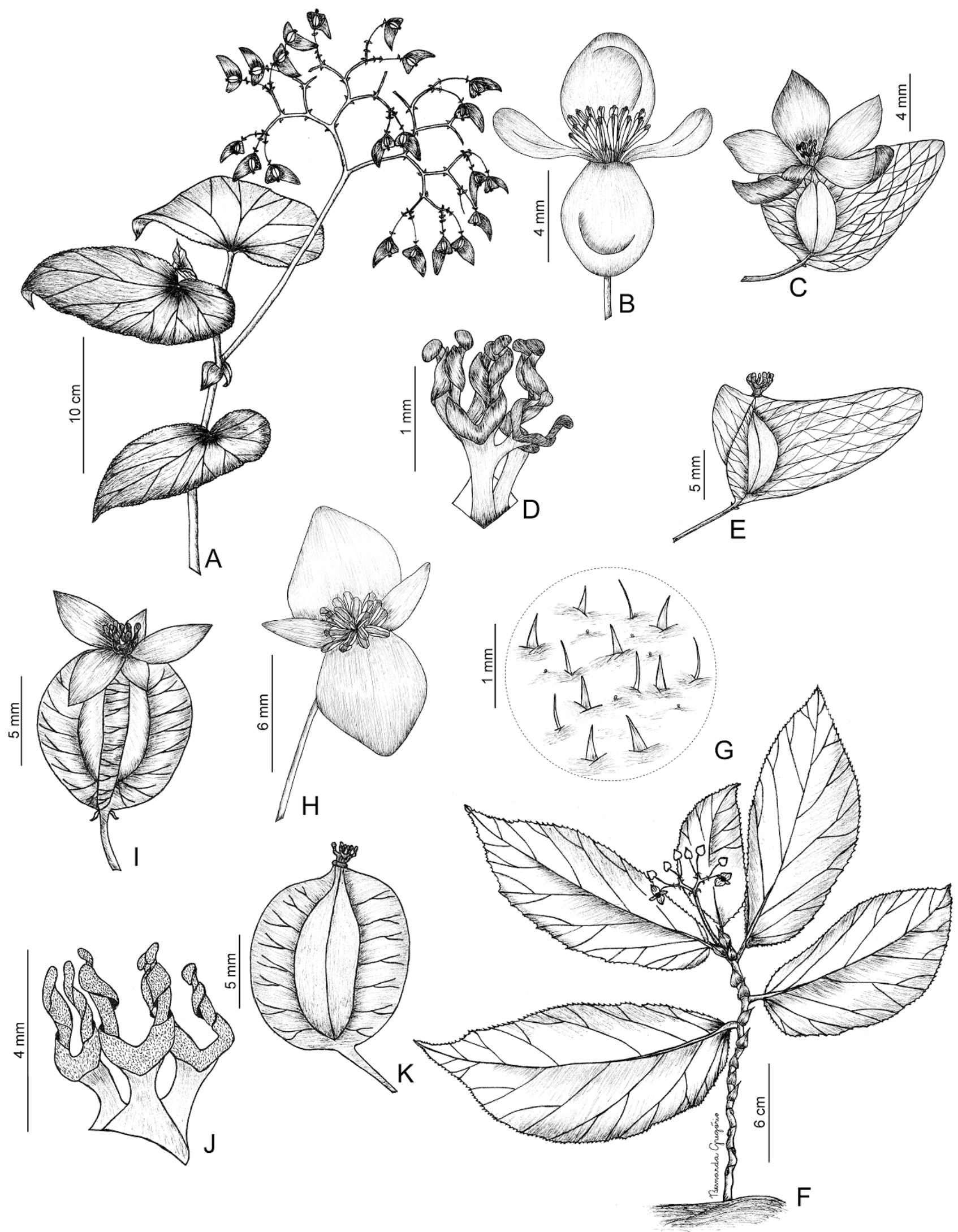

Figura 1. A-E. Begonia angularis: A- ramo com frutos; B- flor estaminada; C- flor pistilada; D- estiletes; E- cápsula. F-K. B. bahiensis: F- hábito; G- detalhe do indumento da face adaxial da lâmina foliar; H- flor estaminada; I- flor pistilada; J- estiletes; K- cápsula. (A, D, E- Gregório 253; B- Mattos Silva 4489; C-Milliken 5106; F-H, J, K- Gregório 231; I- Carvalho 283).

Endêmica do Brasil, B. bahiensis era conhecida somente para o estado da Bahia, tendo sido registrada recentemente também para o Espírito Santo (Kollmann 2012). G7, G8, H8, I8, J8: Floresta ombrófila densa 
montana e submontana, com formação primária ou com perturbação antrópica, mata de cipó, em áreas de transição entre floresta ombrófila densa montana e floresta estacional semidecidual, mata ciliar, capoeira e cabruca. A espécie ocorre sobre troncos em decomposição, rochas ou em solos arenosos ou argilosos, no interior da mata ou em suas bordas, em locais ensolarados ou sombreados. Floresce e frutifica durante o ano todo.

Material selecionado - Buerarema, estrada Buerarema-Pontal de Ilhéus, $14^{\circ} 57^{\prime} 34^{\prime \prime S}, 39^{\circ} 17^{\prime} 59^{\prime \prime} \mathrm{W}, 21$ jul. 1980 (fl., fr.), A.M. Carvalho et al. 283 (CEPEC); Ilhéus, quadra G do CEPEC, 14² $45^{\prime} 21^{\prime \prime S}, 39^{\circ} 14^{\prime} 02^{\prime \prime W}, 20$ mar. 2013 (bot., fl., fr.), B.S. Gregório 231 (HUEFS); ib., s.d. (fl., fr.), L. Riedel 138 (síntipo de $B$ bidentata var insularum: K [foto]); Ipiaú, entre Ipiaú e Ibirapitanga, $14^{\circ} 10^{\prime}$ S, 39 50 50' W, 100 m s.n.m., 26 jan. 1980 (fl.), R.M. Harley et al. 20682 (CEPEC); Itabuna, área do CEPEC, $14^{\circ} 45^{\prime} \mathrm{S}, 39^{\circ} 14^{\prime} \mathrm{W}, 9$ mar. 1977 (fl.), R.M. Harley et al. 19472 (HUEFS, IPA); Itagi, fazenda Palestina, 14016'37"S, 4001'20"W, 24 ago. 2011 (fl., fr.), E. Pessoa et al. 621 (UFP); Itaju do Colônia, fazenda Uruguaiana, $15^{\circ} 08^{\prime} 33^{\prime}$ S, 3943'28"W, 210 m s.n.m., 4 abr. 1976 (fl.), T.R. Soderstrom et al. 2120 (RB); Itamaraju, fazenda Pau-Brasil, $17^{\circ} 01^{\prime} \mathrm{S}, 39^{\circ} 33^{\prime} \mathrm{W}, 11$ maio 2013 (fr.), B.S. Gregório 239 (HUEFS); Itapebi, fazenda Palmeiras, na área da hidrelétrica, $15^{\circ} 56^{\prime} 49,06^{\prime \prime} \mathrm{S}$, 39³7'43,01"W, 120 m s.n.m., 6 dez. 2002 (fl., fr.), E.S. Bonfin et al. 2 (CEN); Jussari, Reserva Particular do Patrimônio Natural Serra do Teimoso, $15^{\circ} 10^{\prime} \mathrm{S}, 39^{\circ} 35^{\prime} \mathrm{W}, 1$ set. 2001 (fl., fr.), R.P. Oliveira et al. $740 a$ (HUEFS); Maracás, s.d. (fl., fr.), C.F.P. Martius s.n. (M 113294 [foto]); Pau Brasil, 11,1 km a oeste de Pau Brasil, na estrada para Água Vermelha, então $1,75 \mathrm{~km}$ ao sul na estrada para a fazenda do Sr. Ney Ferreira de Melo, 15²2'51"S, 39² $42^{\prime} 01^{\prime \prime W}, 500$ 600 m s.n.m., 15 abr. 1997 (fl.), W.W. Thomas et al. 11544 (MBML); Una, fazenda Santa Rosa, 15²17'36"S, 39 $04^{\prime} 31^{\prime \prime} \mathrm{W}, 24$ ago. 1991 (bot., fl.), A.M. Amorim et al. 328 (CEPEC).

Begonia bahiensis é facilmente reconhecida pelo hábito herbáceo-subarbustivo, glabrescente, associado à forma da lâmina foliar oblonga a obovada. A espécie foi originalmente descrita como glabra (Candolle 1859), contudo, observou-se em coletas posteriores a presença de esparsos tricomas simples, finos, tricomas de base espessa e glandulares microscópicos, especialmente nos indivíduos jovens; na fase adulta, o indumento é muitas vezes perdido. Assim, acredita-se que o material utilizado para a descrição da espécie tenha perdido o indumento. Begonia bahiensis possui semelhanças com $B$. sylvatica, contudo, é distinta pelas lâminas foliares com (3) 4 ou 5 nervuras na base (vs. 6 ou 7 nervuras) e cimeiras com 2 ou 3 nós (vs. 3-6 nós).

Dois anos após a descrição de $B$. bahiensis, $B$. bidentata var. insularum foi descrita para a Bahia como endêmica de Ilhéus (Candolle 1861), enquanto Begonia bidentata var bidentata Raddi estaria restrita aos estados do Rio de Janeiro e São Paulo (Jacques 2015). As características que distinguem as variedades, são as mesmas compartilhadas por $B$. bahiensis e $B$. bidentata var. insularum, tais como: lâminas foliares mais largas, com base mais obtusa e margem indiscriminadamente angulosa, estípulas mais largas e

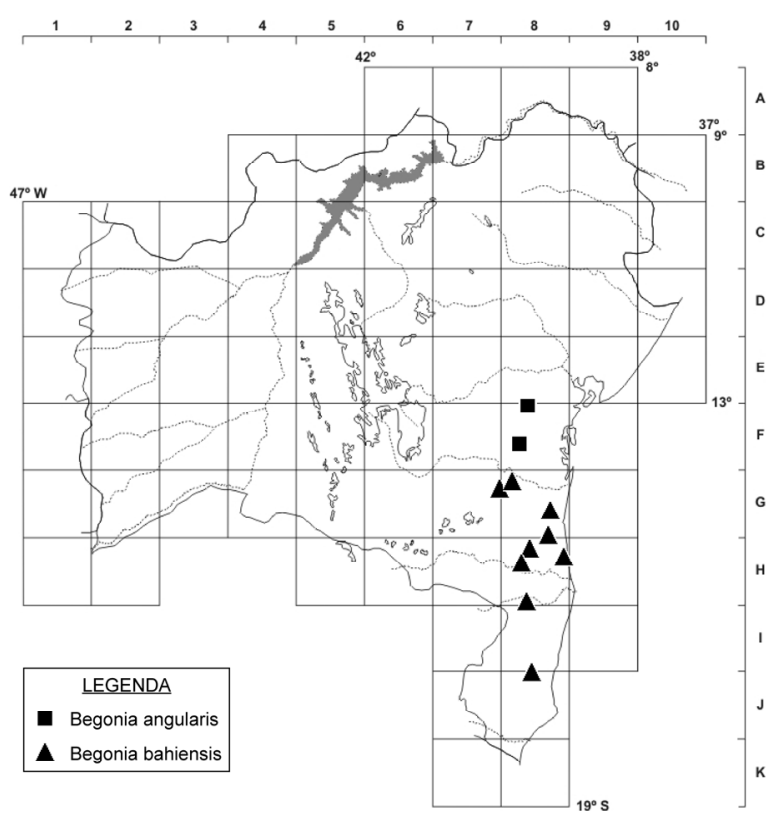

Figura 2. Mapa de distribuição de Begonia angularis e B. bahiensis no estado da Bahia.

tépalas externas das flores estaminadas glabras, destituídas de tricomas estrigosos. Apesar de terem sido encontrados esparsos tricomas glandulares microscópicos nas tépalas das flores estaminadas externas de $B$. bahiensis, bem como em B. bidentata, no estado de São Paulo (Mamede et al. 2012), isso não é empecilho à sinonimização de $B$. bidentata var. insularum em $B$. bahiensis. A característica mais expressiva de $B$. bidentata var. bidentata é a margem foliar duas vezes denteada, ao qual alude o nome da espécie, característica que não foi observada no material-tipo de $B$. bidentata var. insularum. Desse modo, propõe-se neste trabalho a inclusão de $B$. bidentata var. insularum sob B. bahiensis.

\section{Begonia besleriifolia Schott in Sprengel, Syst. Veg.} 4(app.): 408. 1827.

Figuras $3 \mathrm{~A}-\mathrm{F}$ e 4.

Arbustos, 2,5-6 $\mathrm{m}$ alt., pubescentes, tricomas simples. Caule ereto a escandente, glabrescente; entrenós (1,2-)2-8 cm compr. Estípulas 1,5-4 cm $\times$ 3-7 $\mathrm{mm}$, lanceoladas, ápice acuminado, margem inteira, apressas, caducas. Folhas com pecíolo 0,5-1,8 cm compr., seríceo; lâmina $8-13(-15) \times 3-5(-7) \mathrm{cm}$, inteira, assimétrica, basifixa, carnosa, obovada a elíptica, ápice acuminado, base oblíqua, margem inteira a levemente ondulada, glabriúscula na face adaxial, serícea na face abaxial; face adaxial verde, face abaxial verde-clara a vinácea; venação craspedódroma. Cimeiras 9-20 cm compr., 40-60 flores, 4 a 6 nós; brácteas de primeira ordem 1-3 $\times$ 0,3-0,5 mm, lanceoladas, caducas. Flores estaminadas sem bractéolas; tépalas 4 , alvas a róseas, elípticas, côncavas, face abaxial glabra, as externas maiores; estames 28-42, anteras rimosas, conectivos proeminentes. Flores pistiladas com 2 bractéolas 
triangulares, caducas; tépalas 5, alvas, sendo três maiores, elípticas, face abaxial glabra; ovário com placenta partida. Cápsulas $0,7-1,5 \times 2,2-3,8 \mathrm{~cm}$, com tricomas glandulares microscópicos e esparsamente pilosas; alas 3, desiguais, a maior 1,5-2,6 cm larg., ápice arredondado, as menores 2-8 $\mathrm{mm}$ larg., arredondadas. Sementes oblongas.

Endêmica dos estados da Bahia, Espírito Santo e Rio de Janeiro (Jacques 2015). G7, H7, H8: Floresta estacional semidecidual submontana. Ocorre no interior da mata, entre rochas. Floresce entre agosto e outubro e frutifica em novembro e dezembro.

Material selecionado - Itarantim, Serra da Felicíssima, fazenda Bom Jardim, 15\%49'01"S, 4006'57"W, 180-300 m s.n.m., 8 out. 2003 (fl.), A. Salino et al. 9158 (BHCB, MBM); Jussari, Reserva Particular do Patrimônio Natural Serra do Teimoso, 1509'29"S, 39³1'43"W, 13 ago. 1998 (fl.), A.M. Amorim et al. 2473 (CEPEC, MBML); Vitória da Conquista, fazenda Oriente, ca. $30 \mathrm{~km}$ de Vitória da Conquista, 14 $51^{\circ} 58^{\prime \prime S}, 40^{\circ} 50^{\prime} 22^{\prime \prime} \mathrm{W}, 15$ set. 2012 (fl.), C. Azevedo et al. 461 (HUESB).

Material adicional - BRASIL. RIO DE JANEIRO: s.d. (fl. fr.), H.W. Schott 4636 (holótipo de B. besleriifolia: M [foto]).

Begonia besleriifolia é um arbusto com ramos escandentes, encontrado frequentemente apoiado sobre árvores, dando a impressão de se tratar de uma liana; inclusive já foi assim descrito em fichas de herbário. Assemelha-se a $B$. elianeae pelo porte arbustivo, pela forma das estípulas e pelas lâminas foliares. Contudo, é diferenciada desta pelas lâminas foliares com face abaxial serícea (vs. glabrescente a glabra), cimeiras com 40 a 60 flores (vs. 4 a 8 flores), 4 a 6 nós (vs. 2 ou 3 nós) e cápsulas 7-15 mm compr. (vs. 18-20 mm compr.), além das anteras maiores que o filete (vs. anteras menores).

\section{Begonia convolvulacea (Klotzsch) A.DC. in} Martius, Fl. Bras. 4(1): 367. 1861.

Figuras 3G-N e 4.

Trepadeiras, 2-8 $\mathrm{m}$ compr., pilosas a glabriúsculas, esparsos tricomas simples e glandulares microscópicos. Caule escandente, glabrescente; entrenós 3-17 cm compr. Estípulas 1-3 × 0,4-1 cm, lanceoladas, ápice apiculado, margem inteira a levemente ondulada, carenadas, apressas, tardiamente caducas. Folhas com pecíolo 3,7-29,5 cm compr., glabrescente, geralmente com inconspícuo colar de tricomas no ápice; lâmina 5,5-25 × 9-29 cm, inteira, assimétrica, basifixa, papirácea, arredondada a transversalmente elíptica, 2-7-dentada, ápices agudos a acuminados, base cordada a subcordada ou obtusa, margem crenada a irregularmente denteada, pilosa a glabriúscula em ambas as faces; face adaxial verde, face abaxial verde-clara a vinácea; venação actinódroma, 5 ou 6 nervuras na base. Cimeiras 6,8 53,8 cm compr., 70-200 flores, 5-8 nós; brácteas de primeira ordem $1,5-7 \times 0,3-3 \mathrm{~mm}$, lanceoladas, caducas. Flores estaminadas sem bractéolas; tépalas 4, alvas, as externas levemente maiores, obovadas, côncavas, face abaxial com tricomas glandulares microscópicos, as internas oblanceoladas, côncavas, face abaxial com tricomas glandulares microscópicos; estames 20-34, anteras rimosas, conectivos proeminentes. Flores pistiladas com 2 bractéolas lanceoladas, persistentes; tépalas 5, alvas, sendo três levemente maiores, obovadas, face abaxial com tricomas glandulares microscópicos; ovário com placenta inteira. Cápsulas $0,5-1,2 \times 0,8-3,1 \mathrm{~cm}$, com esparsos tricomas glandulares microscópicos a glabras; alas 3, desiguais, a maior 0,4-2 cm larg., ápice redondo, obtuso ou agudo, as menores 1-5 mm larg., redondas a obtusas. Sementes lineares.

Endêmica do Brasil, ocorre nos estados de Alagoas, Bahia, Ceará, Distrito Federal, Espírito Santo, Minas Gerais, Paraná, Pernambuco, Rio de Janeiro, Santa Catarina, São Paulo e Sergipe (Jacques 2015). E6, F8, G8, H8, I8, J8: Floresta ombrófila densa montana e submontana no sul e extremo sul da Bahia, em formação primária ou com perturbação antrópica; além disso, ocorre em mata de grotão no município de Lençóis. A espécie cresce sobre árvores ou rochas, em locais ensolarados ou sombreados, com solos úmidos e arenosos. Floresce durante o ano todo e frutifica de janeiro a março, em maio e de julho a outubro.

Material selecionado - Almadina, Serra do Corcovado, $14^{\circ} 42^{\prime} 21^{\prime \prime S}, 39^{\circ} 36^{\prime} 12^{\prime \prime} \mathrm{W}, 650-750$ m s.n.m., 19 set. 2004 (fl.), W.W. Thomas et al. 14166 (CEPEC); Arataca, Serra das Lontras,

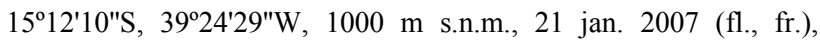
R.A.X. Borges et al. 602 (CEPEC, SPF); Barro Preto, Serra da Pedra Lascada, 1446'13"S, 39³2'10"W, 10 abr. 2012 (bot., fl.), B.S. Gregório 209 (HUEFS); Buerarema, fazenda Santa Rosa, entrada ca. $500 \mathrm{~m}$ à direita, $15^{\circ} 06^{\prime} 19^{\prime \prime} \mathrm{S}, 39^{\circ} 17^{\prime} 20^{\prime \prime} \mathrm{W}, 600 \mathrm{~m}$ s.n.m., 5 fev. 2003 (bot., fl.), P. Fiaschi et al. 1276 (CEPEC); Camacan, Reserva Particular do Patrimônio Natural Serra Bonita, trilha da Bromélia, 15²3'30"S, 39³3'55"W, 12 fev. 2013 (fr.), B.S. Gregório 221 (HUEFS); Floresta Azul, 14 ${ }^{\circ} 56^{\prime}$ S, 39 $9^{\circ} 42^{\prime} \mathrm{W}, 700$ m s.n.m., 23 abr. 2003 (bot., fl.), P. Fiaschi et al. 1479 (CEPEC); Guaratinga, $16^{\circ} 35^{\prime} 02^{\prime \prime S}, 39^{\circ} 46^{\prime} 58^{\prime \prime} \mathrm{W}, 8$ out. 1966 (fr.), R.P. Belém et al. 2733 (UB); Igrapiúna, Reserva Ecológica das plantações Michellin da Bahia, 134ㅇ' $08^{\prime \prime S}, 39^{\circ} 10^{\prime} 03^{\prime \prime W}, 15$ out. 2008 (fr.), J.L. Paixão \& L. Rocha 1509 (CEPEC, HUEFS); Ilhéus, Castelo Novo, Almada, $14^{\circ} 47^{\prime} 20^{\prime \prime S}, 39^{\circ} 02^{\prime} 58^{\prime \prime} \mathrm{W}, 19$ set. 1944 (fl., fr.), H.P. Velloso 1105 (R); Itagibá, Mata da Antena, $14^{\circ} 10^{\prime} 02^{\prime \prime S}, 39^{\circ} 42^{\prime} 40^{\prime \prime} \mathrm{W}, 30$ maio 2008 (fr.), C.E. Ramos \& L.J. Alves 186 (ALCB); Itamaraju, fazenda Pau-Brasil, $17^{\circ} 03^{\prime} \mathrm{S}, 39^{\circ} 32^{\prime} \mathrm{W}, 380 \mathrm{~m}$ s.n.m., 5 dez. 1981 (bot.), G.P. Lewis \& A.M. Carvalho 768 (CEPEC, RB); Ituberá, fragmento do Pacangê, $13^{\circ} 43^{\prime} \mathrm{S}, 39^{\circ} 08^{\prime} \mathrm{W}, 23$ jun. 2006 (fl., fr.), $R$. de M. Valadão \& M.L. Guedes 398 (ALCB); Jaguaquara, distrito de Tesouras, 13040'23"S, 39²4'36"W, 519 m s.n.m., 12 out. 2012 (fl., fr.), D.C. Zappi 3406 (RB); Jussari, Reserva Particular do Patrimônio Natural Serra do Teimoso, 1509'29"S, 39³1'43"W, 13 ago. 1998 (bot.), A.M. Amorim et al. 2460 (CEPEC); Lençóis,

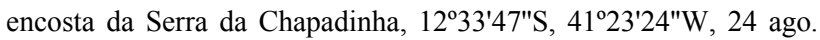
1996 (fl.), R.M. Harley et al. PCD 3778 (ALCB, HRB, HUEFS); Santa Cruz Cabrália, área da Estação Ecológica do Pau-Brasil, $16^{\circ} 16^{\prime} 41^{\prime \prime S}, 39^{\circ} 01^{\prime 2} 29^{\prime W}, 9$ jan. 1984 (bot., fl.), F.S. Santos 68 (CEPEC); Una, Ribeirão das Palmeiras, Serra Javi, $15^{\circ} 09^{\prime} \mathrm{S}$, 38 $18^{\prime} \mathrm{W}, 600-760$ m s.n.m., 6 mar. 1986 (fr.), T.S. Santos et al. 4169 (CEPEC); Wenceslau Guimarães, Estação Ecológica 


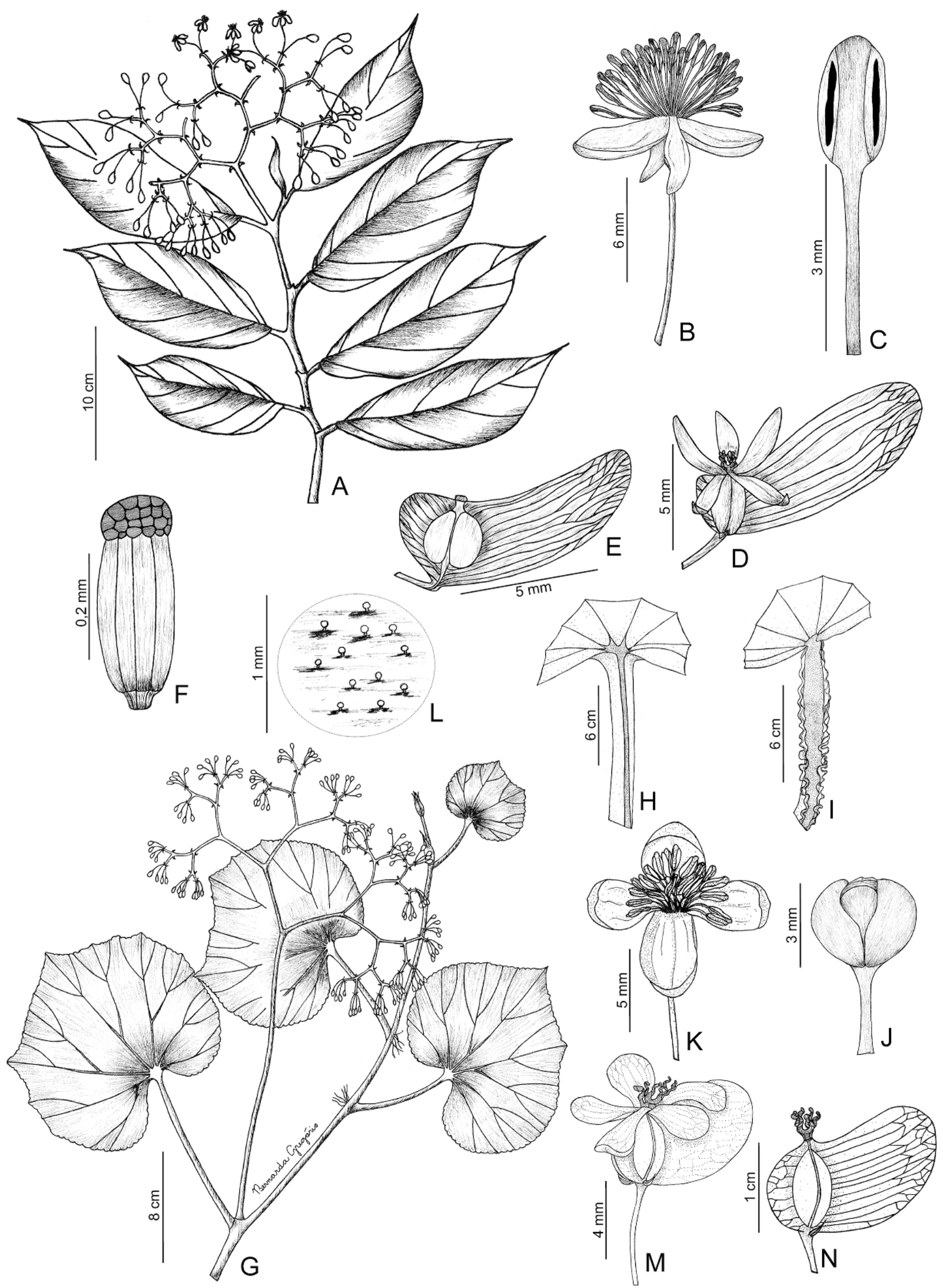

Figura 3. A-F. Begonia besleriifolia: A- ramo florido; B- flor estaminada; C- estame; D- flor pistilada; E- cápsula; F- semente. G-N. B. convolvulacea: G- ramo florido; H- detalhe do pecíolo sulcado; I- detalhe do pecíolo alado; J- botão da flor estaminada; K- flor estaminada; L- detalhe dos tricomas glandulares microscópicos da face abaxial das tépalas estaminadas; M- flor pistilada; N- cápsula. (A-C- Salino 9158; D - Amorim 2473; E, F- Jacques 802; G, J-L- Mori 10684; H- Gregório 217; I- Gregório 221; M, N- Borges 602). 
Estadual de Wenceslau Guimarães, trilha da Petioba, 13\%34'49"S, 39 42'17"W, 24 maio 2013 (est.), B.S. Gregório 250 (HUEFS).

Material adicional - BRASIL. s.d. (fr.), F. Sellow s.n. (B [foto]).

Begonia convolvulacea é facilmente reconhecida pelo hábito trepador associado à lâmina arredondada a transversalmente elíptica, com dois a sete dentes agudos a acuminados, venação actinódroma e inflorescências multifloras. No campo, foram observados, na mesma área, indivíduos com pecíolo alado, muito ou pouco evidente, e outros que em vez da ala, apresentam um sulco longitudinal estreito na região mediana do pecíolo. Contudo, em outras áreas e em cultivo, foram vistos indivíduos dotados de pecíolo com sulco longitudinal no início do desenvolvimento das folhas e, com a maturação do indivíduo, esse sulco se expande para as laterais, apresentando-se como alas rudimentares. Na Bahia, a espécie também apresenta variação na forma da ala maior dos frutos, que pode ser desde largamente elíptica à estreitamente elíptica, bem como na forma da lâmina foliar, que vai de arredondada a transversalmente elíptica; além disso, o colar de tricomas no ápice do pecíolo pode estar presente ou não. Contudo, não foi possível estabelecer um padrão dentro dessa variação morfológica, pois os caracteres se sobrepõem em muitos indivíduos. Estudos populacionais mais detalhados poderão auxiliar no entendimento dessas variações morfológicas na espécie. Begonia convolvulacea partilha com $B$. polygonifolia o caule escandente e a forma das flores estaminadas e sementes. No entanto, difere daquela espécie pelo aspecto geral das folhas, a saber: lâminas arredondadas a transversalmente elípticas (vs. elípticas a oblanceoladas), base cordada a subcordada ou obtusa (vs. oblíqua), nervação actinódroma (vs. craspedódroma) e pecíolos maiores $(>3,5 \mathrm{~cm}$ compr. vs. $<2$ cm compr.).

5. Begonia cucullata Willd., Sp. Pl. 4(1): 414. 1805. Figuras $5 \mathrm{~A}-\mathrm{H}$ e 6.

Ervas, 0,3-1 $\mathrm{m}$ alt., glabriúsculas a glabras, esparsos tricomas glandulares microscópicos. Caule ereto, com esparsos tricomas glandulares microscópicos; entrenós 1,5-6 cm compr. Estípulas $1-2,5 \times 0,5-1,5 \mathrm{~cm}$, ovadas a oblongas, ápice arredondado, margem ciliada a denticulada, apressas, persistentes. Folhas com pecíolo 0,8-6,5 cm compr., glabriúsculo; lâmina 4,5-8 × 3-9,8 cm, inteira, assimétrica, basifixa, subcrassa, ovada a largamente ovada, ápice obtuso a arredondado, base oblíqua, cuculada in vivo, margem crenada a serrilhada, ciliada, glabrescente em ambas as faces; face adaxial verde, face abaxial verde-clara; venação actinódroma, 5-8 nervuras na base. Cimeiras 5,5-8,5 cm compr., 5-10 flores, 2 ou 3 nós; brácteas de primeira ordem $4-5,5 \times 2-3,6 \mathrm{~mm}$, ovadas, persistentes. Flores estaminadas sem bractéolas; tépalas 4 , alvas a róseas, as externas maiores, orbiculares, face abaxial glabra,

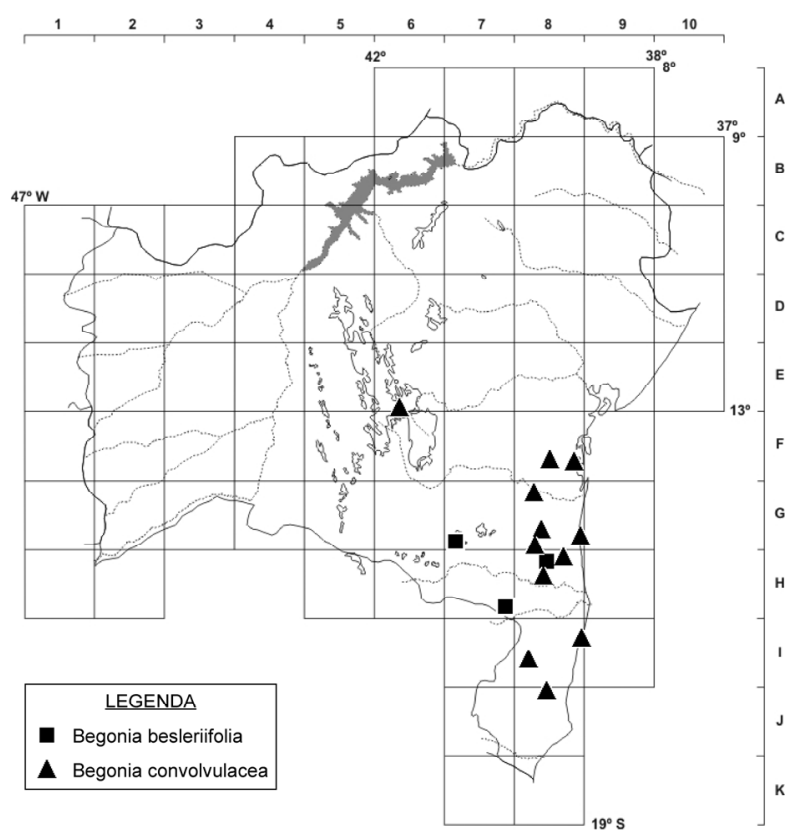

Figura 4. Mapa de distribuição de Begonia besleriifolia e B. convolvulacea no estado da Bahia.

as internas oblanceoladas, face abaxial glabra; estames 34-46, anteras rimosas, conectivos proeminentes. Flores pistiladas com 3 bractéolas obovadas, persistentes; tépalas 5, alvas a róseas, três levemente maiores, largamente obovadas a oblanceoladas, face abaxial glabra; ovário com placenta partida. Cápsulas 1,5-1,8 × 1,2-1,5 cm, com esparsos tricomas glandulares microscópicos; alas 3 , desiguais, a maior 1,2-1,7 cm larg., ápice arredondado, as menores 3-5 $\mathrm{mm}$ larg., arredondadas. Sementes fusiformes.

Begonia cucullata ocorre na Argentina, Brasil, Paraguai e Uruguai (Jacques 2002). No Brasil, é encontrada na Bahia, Distrito Federal, Espírito Santo, Goiás, Mato Grosso, Mato Grosso do Sul, Minas Gerais, Paraná, Rio de Janeiro, Rio Grande do Sul, Santa Catarina e São Paulo (Jacques 2015). E9, H8: Floresta ombrófila densa montana e submontana. Habita ambientes úmidos, alterados, sombreados ou à meia sombra, em solos arenosos ou alagados. Encontrada com flores em junho e com frutos em fevereiro e junho.

Material selecionado - Camacan, Reserva Particular do Patrimônio Natural Serra Bonita, jardim da sede, 15⒉'30"S, 39³3'55"W, 13 fev. 2013 (fr.), B.S. Gregório 229 (HUEFS); Salvador, Ondina, $12^{\circ} 58^{\prime} 16^{\prime \prime} \mathrm{S}, 38^{\circ} 30^{\prime} 39^{\prime \prime} \mathrm{W}, 15$ jun. 1954 (fl., fr.), D.R. Espinosa 916 (BAH).

Begonia cucullata é reconhecida in vivo pela base da lâmina foliar cuculada, estípulas ovadas a oblongas com ápice arredondado a obtuso e margem ciliada a denticulada. A espécie é comumente cultivada pelas flores vistosas e apresenta, inclusive, diversos cultivares. Em Camacan, B. cucullata foi encontrada no jardim da RPPN Serra Bonita e, segundo a proprietária, o espécime havia sido coletado no interior da mata da reserva. 


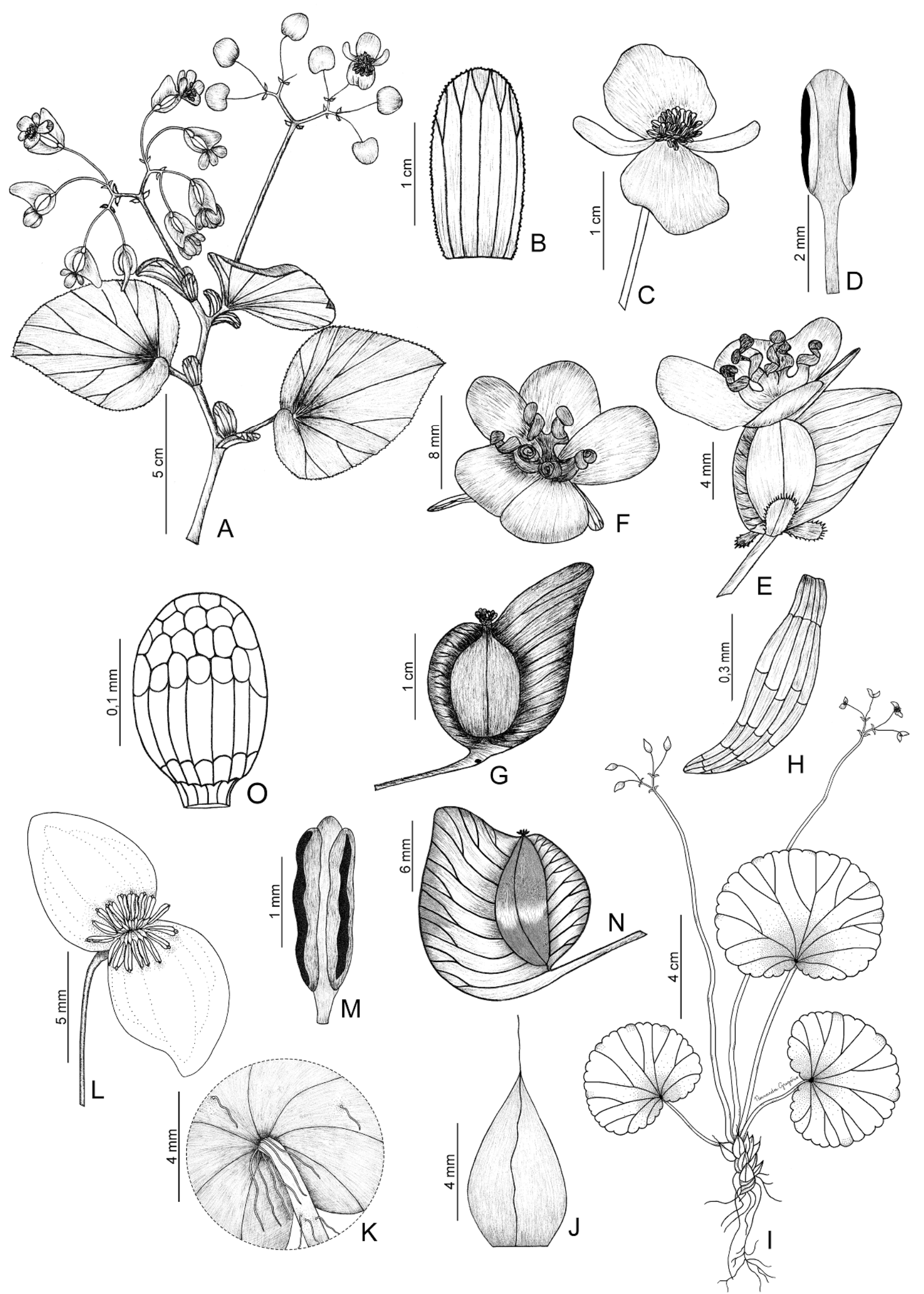

Figura 5. A-H. Begonia cucullata: A- ramo florido; B- estípula; C- flor estaminada; D- estame; E- flor pistilada; F- flor pistilada, vista de cima; G- cápsula; H- semente. I-O. B. delicata: I- hábito; J- estípula; K- detalhe do colar de tricomas no ápice do pecíolo; L- flor estaminada; M- estame; N- cápsula; O-semente. (A-F- Espinosa 916; G, H- Gregório 229; I-L- Pinto 587; M-O- holótipo Pinto 53-55). 
Begonia cucullata assemelha-se a $B$. fischeri pelo tipo de hábito, lâminas foliares basifixas e presença de três bractéolas nas flores pistiladas. Contudo, difere daquela espécie pelo indumento glabriúsculo a glabro (vs. viloso), estípulas com ápice arredondado e margem ciliada a denticulada (vs. ápice agudo e margem fimbriada), e base das lâminas foliares obtusa (vs. cordada).

6. Begonia delicata Gregório \& J.A.S.Costa, Phytokeys 44: 3. 2015.

Figuras 5I-O e 6.

Ervas, $11-15 \mathrm{~cm}$ alt., vilosas a glabrescentes, tricomas simples, finos, de base espessa, e esparsos tricomas glandulares microscópicos. Caule prostrado, piloso; entrenós 1-3 mm compr. Estípulas 7-8 $\times 3-4$ $\mathrm{mm}$, ovadas, ápice apiculado, margem inteira, carenadas, apressas, persistentes. Folhas com pecíolo 3,5-9 cm compr., viloso a glabrescente, colar de tricomas no ápice; lâmina 3,5-7,8 × 4-9,2 cm, inteira, simétrica a levemente assimétrica, basifixa, membranácea, arredondada a transversalmente elíptica, ápice arredondado, base cordada, margem crenada, ciliada, esparsamente pilosa a glabrescente e verdeclara em ambas as faces; venação actinódroma, 7-9 nervuras na base. Cimeiras 9-20 cm compr., 4-14 flores, 1 ou 2 nós; brácteas de primeira ordem ca. 1,5 $\times$ $0,8 \mathrm{~mm}$, lanceoladas, persistentes. Flores estaminadas sem bractéolas; tépalas 2, ovadas a elípticas, face abaxial com tricomas glandulares microscópios; estames 16-22, anteras rimosas, conectivos proeminentes. Flores pistiladas [não vistas], com 2 bractéolas lanceoladas, persistentes [obtidas pelo botão]; ovário com placenta partida [obtido pelo botão]. Cápsulas ca. 1,2 × 1,3 cm, com esparsos

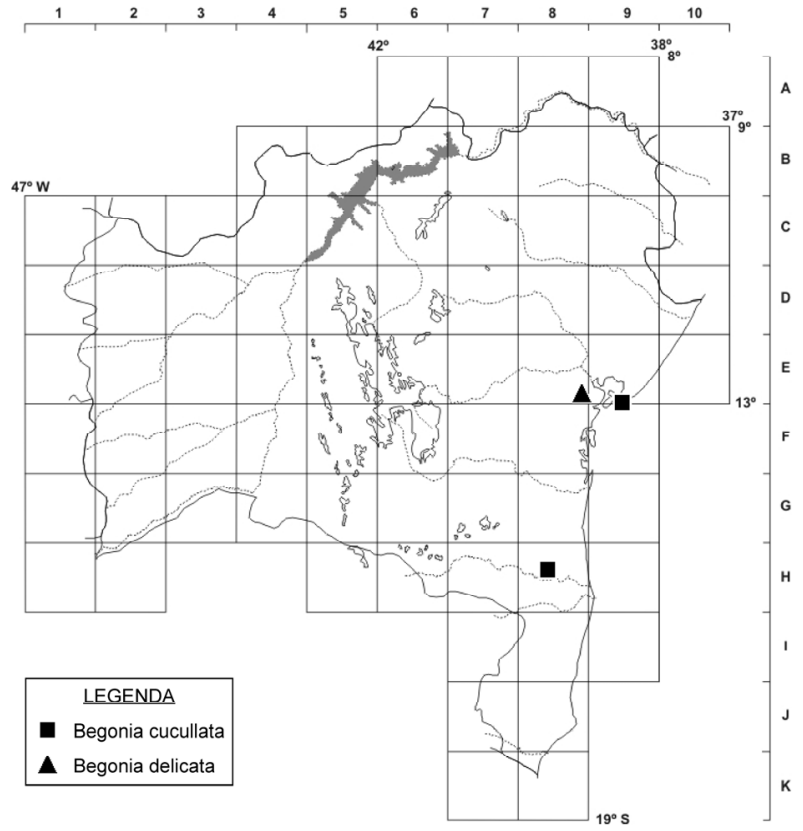

Figura 6. Mapa de distribuição de Begonia cucullata e B. delicata no estado da Bahia. tricomas glandulares microscópicos; alas 3, desiguais, a maior ca. $5 \mathrm{~mm}$ larg., ápice arredondado, as menores ca. $3 \mathrm{~mm}$ larg. Sementes elípticas a oblongas.

Endêmica do estado da Bahia (Gregório et al. 2015). E8: Floresta ombrófila, em vegetação de subbosque. Ocorre sobre pedras cobertas por musgos. Foi encontrada florida em junho e outubro, e com frutos em junho.

Material examinado - São Felipe, Serra da Copioba, jun. 1953 (fl, fr), G. Pinto 53-55. (holótipo de B. delicata: ALCB); ib., out. 1950 (fl), G. Pinto 587 (parátipo de B. delicata: RB).

Begonia delicata é uma erva delgada, caracterizada pelo caule rizomatoso revestido por estípulas, pecíolo com um colar de tricomas no ápice, lâminas foliares arredondadas a transversalmente elípticas e margem crenada. Assemelha-se a B. alchemilloides A.DC., da qual difere pelo colar de tricomas no ápice do pecíolo (vs. pecíolo totalmente glabro), estípulas e brácteas de primeira ordem com margem inteira (vs. laciniadas) e pelas flores estaminadas com 2 tépalas (vs. 4 tépalas).

7. Begonia digitata Raddi, Mem. Mat. Fis. Soc. Ital. Sci. Modena, Pt. Mem. Fis. 18: 406. 1820.

Figuras $7 \mathrm{~A}-\mathrm{E}$ e 8.

Subarbustos, 2-4 m alt., estrigosos, tricomas simples de base espessa e escamas fimbriadas. Caule ereto, glabrescente; entrenós 2-9 cm compr. Estípulas $1-1,8 \mathrm{~cm} \times 4-6 \mathrm{~mm}$, triangulares, ápice acuminado, margem levemente inteira, carenadas, apressas, caducas. Folhas com pecíolo 7-15(-29) cm compr., estrigoso; lâmina digitada, 6-9 segmentos, segmentos medianos 13-23,5 × 3,5-6 cm, assimétricos, basifixos, papiráceos, elípticos a lanceolados, ápice acuminado, base oblíqua, margem serrilhada, ciliada, estrigosa em ambas as faces, mais densamente na adaxial, face abaxial com indumento concentrado nas nervuras; face adaxial verde, face abaxial verde a ferrugínea; folíolos com venação semicraspedódroma. Cimeiras $18-85 \mathrm{~cm}$ compr., 100-400 flores, 5-10 nós; brácteas de primeira ordem $1-1,5 \times 0,6-0,8 \mathrm{~mm}$, triangulares, caducas. Flores estaminadas sem bractéolas; tépalas 4 , alvas, tamanhos semelhantes, as externas obovadas, côncavas, face abaxial pilosa, as internas obovadas, côncavas, face abaxial glabra; estames $32-74$, anteras rimosas, conectivos proeminentes. Flores pistiladas com 2 bractéolas triangulares, caducas; tépalas 5 , alvas, sendo três levemente maiores, elípticas a oblanceoladas, face abaxial glabrescente; ovário com placenta inteira. Cápsulas 4-6 $\mathrm{mm} \times 1,1-1,7 \mathrm{~cm}$, sem tricomas glandulares microscópicos, pilosas; alas 3, iguais a subiguais, 4-6 $\mathrm{mm}$ larg., arredondadas. Sementes oblongas.

Endêmica do Brasil, ocorre nos estados da Bahia, Espírito Santo, Minas Gerais e Rio de Janeiro (Jacques 2015). G8: Floresta ombrófila densa montana e submontana. Ocorre em bordas de matas, áreas em regeneração secundária e topos de morro. Floresce de novembro a abril, e frutifica em dezembro, fevereiro e abril. 


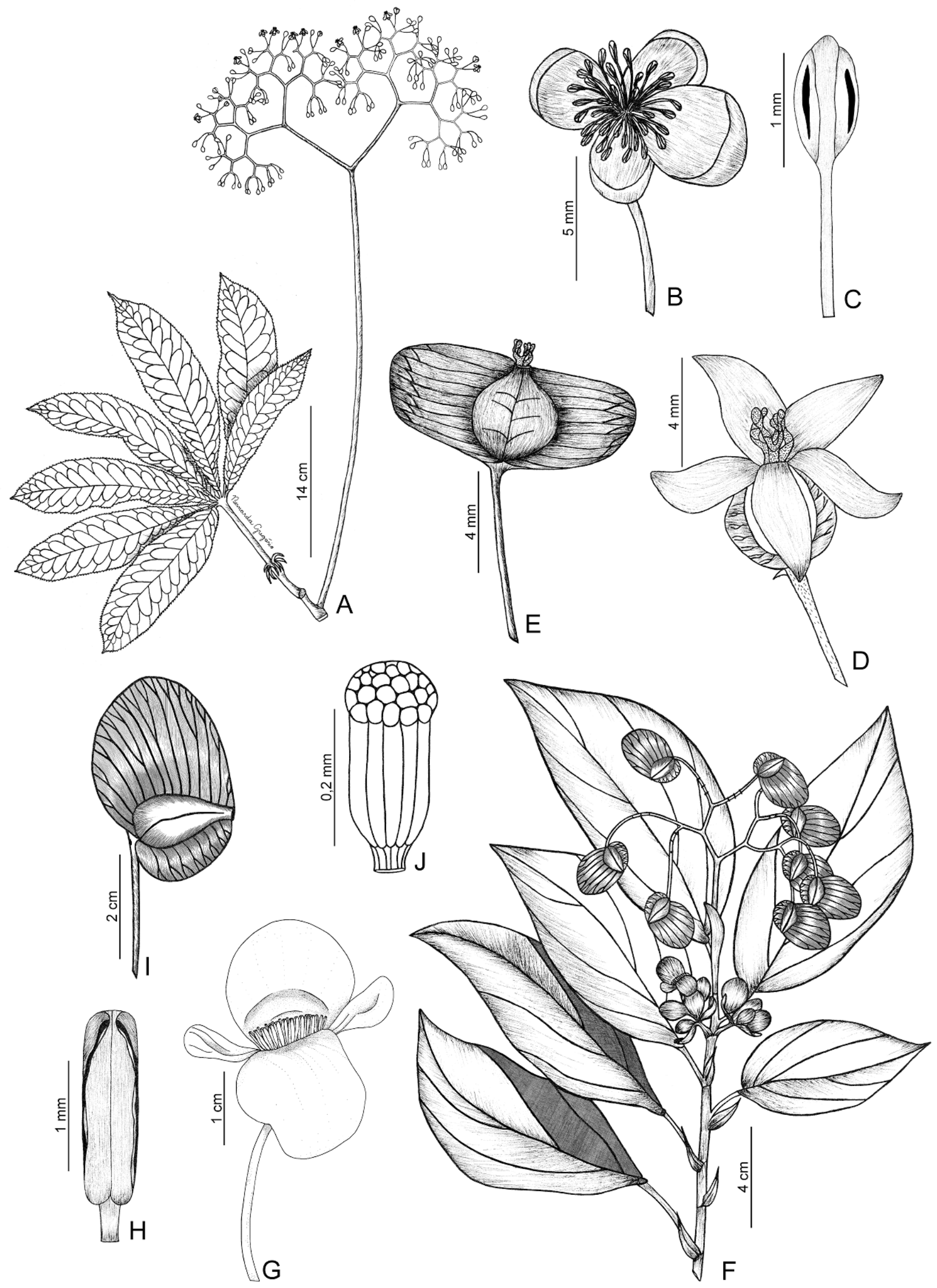

Figura 7. A-E. Begonia digitata: A- ramo florido; B- flor estaminada; C- estame; D- flor pistilada; E- cápsula. F-J. B. elianeae: F- ramo com flores e frutos; G- flor estaminada; H- estame; I- cápsula; J- semente. (A-C- Gregório 199; D- Amorim 4081; E- Borges 452; F-H- holótipo Thomas 10863; I, J- Fiaschi 1704). 
Material selecionado - Almadina, Serra do Corcovado, 14²'2'21"S, 39³6'12"W, 17 dez. 2006 (fl., fr.), R.A.X. Borges et al. 452 (CEPEC, MBML, SP); Barro Preto, Serra da Pedra Lascada, 14²46'13"S, 39²12'10"W, 10 abr. 2012 (bot., fl., fr.), B.S. Gregório et al. 199 (CEPEC, HUEFS).

Material adicional - BRASIL. s.d. (fr.), F. Sellow 2176 (B [foto]).

Begonia digitata é facilmente identificada dentre as Begoniaceae que ocorrem no estado pelas lâminas foliares digitadas com 6-9 segmentos. Assemelha-se a $B$. semidigitata pelo hábito subarbustivo, indumento estrigoso, forma das tépalas nas flores estaminadas e dos frutos. Begonia digitata diferencia-se facilmente de $B$. semidigitata pelas folhas compostas (vs. simples).

\section{Begonia elianeae Gregório \& J.A.S.Costa, Phytokeys} 44: 6. 2015.

Figuras $7 \mathrm{~F}-\mathrm{J}$ e 8.

Arbustos, 1-2,5 m alt., glabriúsculos, esparsos tricomas simples, estrelados e glandulares microscópicos. Caule ereto a escandente, glabriúsculo; entrenós 1,7-5 cm compr. Estípulas 1,7-3,5 cm × 6-8 $\mathrm{mm}$, lanceoladas, ápice apiculado, margem inteira, apressas, persistentes. Folhas com pecíolo 1,3-3,3 cm compr., glabriúsculo; lâmina 13-18,2 × 6,2-8 cm, inteira, assimétrica, basifixa, crassa, oblonga a obovada, ápice acuminado, base levemente oblíqua, margem inteira a levemente ondulada, glabrescente a glabra em ambas as faces; face adaxial verde, face abaxial verde-clara a vinácea; venação craspedódroma. Cimeiras 9-15 cm compr., 4-8 flores, 2 ou 3 nós; brácteas de primeira ordem ca. $1,5 \mathrm{~cm} \times 6 \mathrm{~mm}$, obovadas, caducas. Flores estaminadas sem bractéolas; tépalas 4, alvas, as externas maiores, orbiculares a ovadas, côncavas, face abaxial glabrescente, as internas, elípticas a oblanceoladas, côncavas, face abaxial glabra; estames 26-34, anteras rimosas, conectivos não proeminentes. Flores pistiladas [não vistas], com 2 bractéolas caducas [não vistas; inferidas a partir das cicatrizes no botão]; ovário com placenta partida. Cápsulas $1,8-2 \times 2,7-3,7 \mathrm{~cm}$, com tricomas glandulares microscópicos, glabrescentes; alas 3, desiguais, a maior 1,7-2,1 cm larg., ápice obtuso a arredondado, as menores 6-8 mm larg., redondas. Sementes oblongas.

Endêmica da Bahia (Gregório et al. 2015). G8, H8, I8: Floresta ombrófila densa montana e submontana. Ocorre sobre rochas, comumente apoiando seus ramos em troncos de árvores na beira de trilhas e em matas perturbadas. Foi encontrada com flores nos meses de maio, agosto e outubro, e com frutos em maio e outubro.

Material examinado - Buerarema, estrada São José da Vitória-Buerarema, ramal à direita, ca. $1 \mathrm{~km}$ de São José, estrada de acesso para Pedra Branca, $15^{\circ} 05^{\prime} \mathrm{S}, 39^{\circ} 19^{\prime} \mathrm{W}, 15$ out. 2003 (fl, fr.), $P$. Fiaschi et al. 1704 (CEPEC, SPF); Itabuna, fazenda Santa Clara, distrito Ribeirão dos Cachorros, entrada à $200 \mathrm{~m}$ após a ponte da Bananeira da rodovia BR-101, 21 ago. 1972 (fl.), R.S. Pinheiro

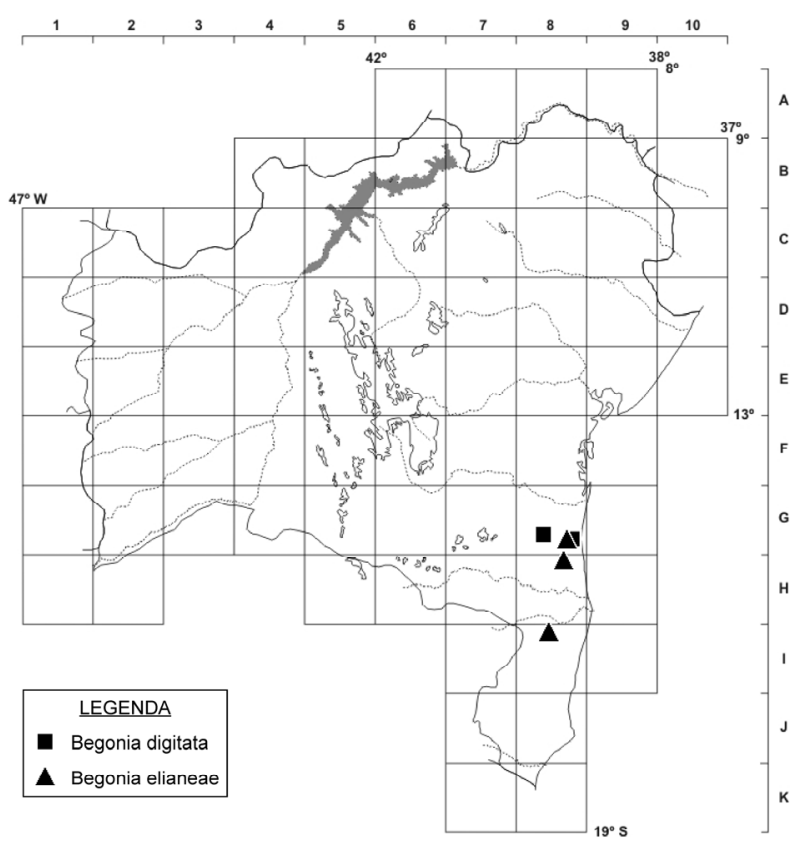

Figura 8. Mapa de distribuição de Begonia digitata e B. elianeae no estado da Bahia.

1930 (CEPEC); Jussari, 1506'58"S, 39³1'58"W, 10 maio 1995 (fl, fr.), W.W. Thomas et al. 10863 (holótipo de B. elianeae: CEPEC).

Begonia elianeae é uma espécie arbustiva, com lâminas foliares, flores e cápsulas relativamente grandes. A espécie possui maior similaridade morfológica com $B$. besleriifolia (ver comentários acima, sobre $B$. besleriifolia).

9. Begonia epibaterium Mart. ex A.DC. in Martius, Fl. Bras. 4(1): 362. 1861.

= Begonia epibaterium var. angustialata A.DC. in Martius, Fl. Bras. 4(1): 363. 1861. Syn. nov.

Figuras 9A-E e 10.

Trepadeiras, 2-4 m compr., pilosas, tricomas simples e glandulares microscópicos. Caule escandente, piloso e com esparsos tricomas glandulares microscópicos; entrenós 1,5-10 cm compr. Estípulas 1,3-3,3 × 0,5-1,2 cm, lanceoladas, ápice apiculado, margem inteira, carenadas, apressas, persistentes. Folhas com pecíolo 1,1-4 cm compr., piloso e com esparsos tricomas glandulares microscópicos; lâmina 6,4-14,5 × 3,3-9,5 cm, inteira, levemente assimétrica, basifixa, papirácea, ovada ou elíptica, ápice acuminado, base cordada a subcordada, margem crenada a irregularmente denteada, ciliada, pilosa em ambas as faces, mais densamente na face abaxial, especialmente nas nervuras, glabrescente na face adaxial; face adaxial verde, face abaxial verde-clara; venação actinódroma, 5-7 nervuras na base. Cimeiras 10,2-34 cm compr., 80-170 flores, 5 ou 6 nós; brácteas de primeira ordem 2,9-4 × 1,3-1,8 mm, lanceoladas, persistentes. Flores estaminadas sem bractéolas; tépalas 4, alvas, as externas maiores, ovadas a orbiculares, côncavas, face abaxial glabrescente, com esparsos tricomas glandulares microscópicos, as 


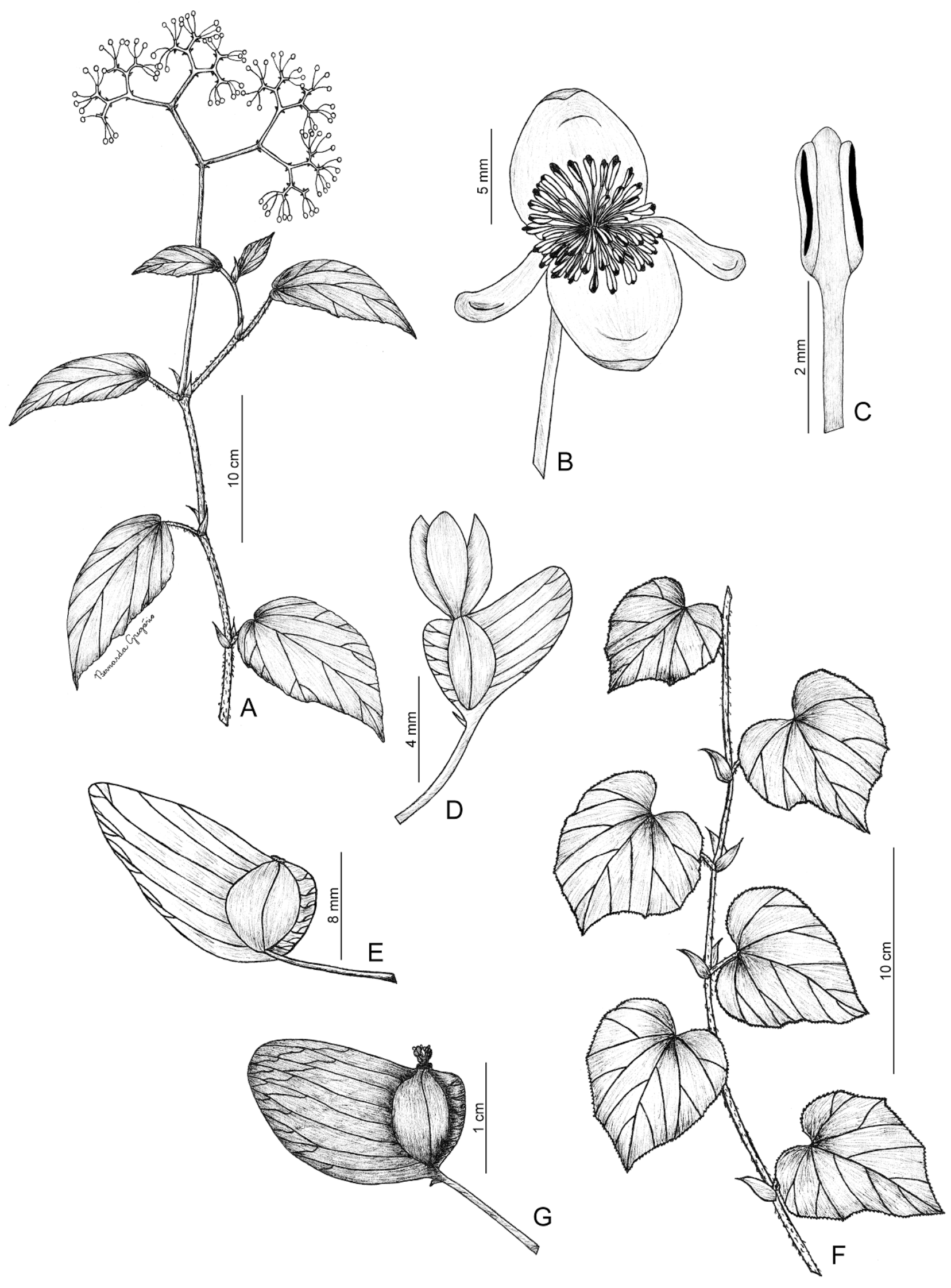

Figura 9. A-E. Begonia epibaterium: A- ramo florido; B- flor estaminada; C- estame; D- flor pistilada jovem; E- cápsula. F, G. B. fagifolia: F- ramo; G- cápsula. (A-C-Santos 3408; D, E- Santos 3632; F, G- Thomas 9246). 
internas oblanceoladas, côncavas, face abaxial glabra; estames 52-64, anteras rimosas, conectivos proeminentes. Flores pistiladas [imaturas] com 2 bractéolas lanceoladas, caducas; tépalas 5, alvas, desiguais, 3 levemente maiores, elípticas, face abaxial com esparsos tricomas glandulares microscópicos; ovário com placenta inteira. Cápsulas $7-9,5 \mathrm{~mm} \times$ 1,5-2,5 cm, com tricomas glandulares microscópicos, glabrescentes; alas 3, desiguais, a maior $0,9-1,6 \mathrm{~cm}$ larg., ápice agudo a arredondado, as menores 1-2,2 $\mathrm{mm}$ larg., arredondadas. Sementes lineares.

Endêmica da Bahia, é conhecida somente para o município de Ilhéus. G8: Floresta ombrófila, cabruca antiga, capoeira e em mata secundária. Cresce sobre árvores ou rochas, em locais ensolarados ou sombreados, em solos arenosos úmidos. Floresce de junho a dezembro e foi encontrada com frutos em setembro e dezembro.

Material selecionado - Ilhéus, Castelo Novo, nas margens do rio Almada, 14\% $47^{\prime} 20^{\prime \prime} \mathrm{S}, 39^{\circ} 02^{\prime} 58^{\prime \prime} \mathrm{W}, 8$ maio 2013 (est.), B.S Gregório 234 (HUEFS); ib., s.d. (fl.), C.F.P. Martius s.n. (M 145674 [foto]); ib., s.d. (bot., fl.), L. Riedel 588 (K [foto]).

Begonia epibaterium é facilmente identificada pelo hábito trepador, por ser revestida por indumento piloso e pela lâmina foliar ovada a elíptica, com ápice acuminado. Candolle (1861) propôs a variedade angustialata baseado na ala maior da cápsula, sendo oblonga e mais estreita, com 6-8 mm de largura (vs. ovada e mais larga, $1,2 \mathrm{~cm}$ larg.). Entretanto, as alas de muitas espécies de Begoniaceae variam muito, até mesmo dentro da mesma cimeira, como comentado pelo próprio Candolle (1861). Durante a análise das coleções de B. epibaterium verificou-se que na exsicata da coleta Velloso 1089 (R 41860), realizada nas imediações de Castelo Novo (Ilhéus), localidade-tipo

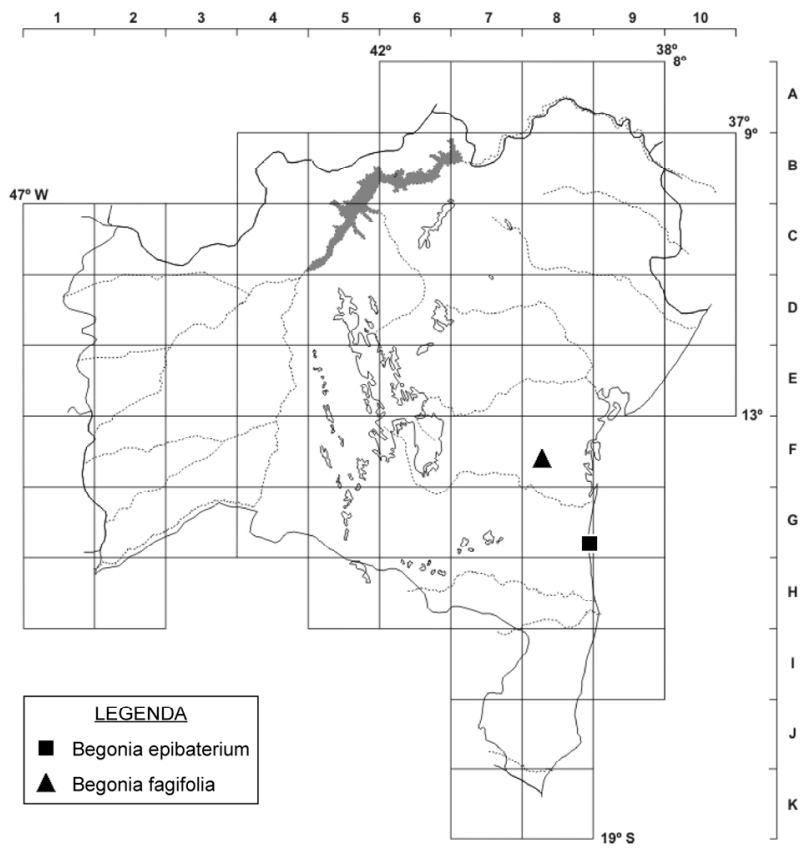

Figura 10. Mapa de distribuição de Begonia epibaterium e B. fagifolia no estado da Bahia. da variedade, existem infrutescências com as duas formas de alas. Portanto, devido à elevada variedade morfológica encontrada nas coleções analisadas de $B$. epibaterium, conclui-se que os caracteres utilizados por Candolle são insuficientes para a manutenção de variedades dessa espécie.

\section{Begonia fagifolia Otto \& Dietr., Allg.} Gartenzeitung 4: 356. 1836.

Figuras 9F, G e 10.

Trepadeiras, 3-5 m compr., pilosas, tricomas simples e glandulares microscópicos. Caule escandente, piloso e com esparsos tricomas glandulares microscópicos; entrenós 4-4,7 cm compr. Estípulas $1,2-1,8 \mathrm{~cm} \times 5-7 \mathrm{~mm}$, triangulares, ápice apiculado, margem inteira, carenadas, apressas, persistentes. Folhas com pecíolo 1,7-2 cm compr., piloso e com esparsos tricomas glandulares microscópicos; lâmina 7$8 \times 5,6-6,8 \mathrm{~cm}$, inteira, assimétrica, basifixa, papirácea, largamente ovada, ápice agudo, base cordada, margem serrilhada, ciliada, pilosa em ambas as faces, mais densamente na adaxial, face abaxial com indumento concentrado nas nervuras; face adaxial verde, face abaxial verde-pálida; venação actinódroma, 5 ou 6 nervuras na base. Cimeiras 20-30 cm compr., 30-70 flores, 5 ou 6 nós; brácteas de primeira ordem 2-3 $\times 3-4$ $\mathrm{mm}$, deltadas, persistentes. Flores estaminadas sem bractéolas; tépalas 4, alvas, as externas maiores, ovadas a orbiculares, côncavas, face abaxial glabrescente, com esparsos tricomas glandularess microscópicos, as internas oblanceoladas, côncavas, face abaxial glabra; estames 50-58, anteras rimosas, conectivos proeminentes. Flores pistiladas com 2 bractéolas lanceoladas, persistentes; tépalas 5, alvas, três levemente maiores, elípticas, face abaxial com esparsos tricomas glandulares; ovário com placenta inteira. Cápsulas 0,9$1,1 \times 1,5-2,5 \mathrm{~cm}, \quad$ com tricomas glandulares microscópicos, glabrescentes; alas 3, desiguais, a maior 1-1,5 cm larg., ápice arredondado a obtuso, as menores 1-3 mm larg., arredondadas. Sementes lineares.

Endêmica do Brasil, ocorre nos estados da Bahia, Espírito Santo e Rio de Janeiro (Kollmann 2012). Na Bahia, foi encontrada somente no município de Wenceslau Guimarães. F8: Floresta ombrófila densa montana. Habita áreas com sombreamento parcial. Encontrada com frutos em maio.

Material examinado - Wenceslau Guimarães, ca. $3 \mathrm{~km}$ a oeste de Nova Esperança, a oeste da orla da Reserva Estadual Wenceslau Guimarães, $13^{\circ} 36^{\prime} \mathrm{S}, 39^{\circ} 43^{\prime} \mathrm{W}, 500-600$ m s.n.m., 14 maio 1992 (fr.), W.W. Thomas et al. 9246 (CEPEC).

Material adicional - BRASIL. RIO DE JANEIRO: 1835 (fr.), C. Gaudichaud 1060 (B [foto]); ib., Jardim Botânico, 12 set. 1935 (fl.), P. Occhioni s.n. (RB 48881).

Begonia fagifolia caracteriza-se pelo hábito trepador, indumento piloso, lâmina foliar largamente ovada, margem serrilhada e estípulas persistentes. Assemelha-se a B. epibaterium pelo caule escandente, piloso e estípulas persistentes. Contudo, pode ser diferenciada daquela espécie pelas lâminas foliares 
largamente ovadas (vs. ovadas a elípticas), de margem serrilhada (vs. irregularmente denteada a crenada) e ápice agudo (vs. acuminado). As informações florais foram obtidas a partir do material adicional, pois o espécime da Bahia foi encontrado apenas com frutos.

\section{Begonia fellereriana Irmsch., Bot. Jahrb. Syst. 78: 187. 1959.}

Figuras 11A-E e 12.

Ervas, 5-40 cm alt., pubescentes a tomentosas, tricomas estrelados. Caule prostrado ou decumbente, glabrescente; entrenós 1-3 mm compr. Estípulas 1,52,1 × 1-1,4 cm, triangulares, ápice apiculado, margem inteira a levemente ondulada, carenadas, apressas, persistentes. Folhas com pecíolo 1,7-12 cm compr., glabriúsculo; lâmina 3,8-10,5 × 4,3-12 cm, inteira, levemente assimétrica, peltada, cartácea, orbicular, ápice arredondado, margem plana a levemente ondulada, pubescente a tomentosa em ambas as faces, mais densamente na face abaxial, glabrescente na face adaxial; face adaxial verde, face abaxial ferrugínea; venação actinódroma, 7 ou 8 nervuras irradiando do ápice do pecíolo. Cimeiras 16-65 cm compr., 30-60 flores, 4 ou 5 nós; brácteas de primeira ordem caducas [não vistas]. Flores estaminadas sem bractéolas; tépalas 2, alvas, largamente ovadas a orbiculares, face abaxial glabrescente; estames 9-28, anteras rimosas, conectivos não proeminentes. Flores pistiladas [não vistas], com 2 bractéolas caducas [obtidas a partir das cicatrizes nas cápsulas]; ovário com placenta inteira. Cápsulas 6-8 × 4,6-9 mm, sem tricomas glandulares microscópicos, glabrescentes; alas 3, subguais, 0,8-2,5 mm larg., arredondadas. Sementes oblongas.

Endêmica do estado da Bahia (Jacques 2015), ocorre somente em Monte Santo. C8: Caatinga e campo rupestre. Cresce sobre rochas, em locais ensolarados. Floresce em fevereiro e outubro e frutifica em fevereiro.

Material selecionado - Monte Santo, subida para a igreja ao lado da escada, $10^{\circ} 26^{\prime} 19^{\prime} \mathrm{S}, 39^{\circ} 20^{\prime} 09^{\prime \prime} \mathrm{W}, 27$ fev. 2000 (fl., fr.), A.M. Giulietti \& R.M. Harley 1865 (HUEFS, SPF); ib., s.d. (fl.), C.F.P. Martius 2303 (holótipo de B. fellereriana: M [foto]).

Begonia fellereriana é facilmente reconhecida pelo caule rizomatoso com entrenós indistintos, recoberto por estípulas, indumento constituído por tricomas estrelados e folhas peltadas. Assemelha-se a B. umbraculifera pelas folhas peltadas, lâminas orbiculares, levemente assimétricas e flores estaminadas com duas tépalas. Essas espécies diferem pelo indumento pubescente a tomentoso em $B$. fellereriana (vs. glabriúsculo a glabro em $B$. umbraculifera), caule prostrado ou decumbente (vs. ereto), entrenós $0,1-0,3 \mathrm{~cm}$ compr. (vs. 0,7-3,8 cm compr.) e estípulas persistentes (vs. caducas).

12. Begonia fischeri Schrank, P1. Rar. Hort. Monac. 2(6): tab. 59. 1820 [como '1819'].

Figuras $11 \mathrm{~F}-\mathrm{L}$ e 12.

Ervas ou subarbustos, 0,3-1,5 m alt., vilosos, tricomas simples. Caule ereto, viloso a glabrescente; entrenós 2,5-15,2(-18) cm compr. Estípulas 0,5-1,7 cm $\times$ 3-6 mm, lanceoladas, ápice agudo a acuminado, margem fimbriada, apressas, persistentes. Folhas com pecíolo 1,3-6,5(-13) cm compr., viloso; lâmina 3-8,5 $\times$ 2-6,5 cm, inteira, assimétrica, basifixa, papirácea, ovada, ápice agudo a acuminado, base cordada, margem crenada a denteada, ciliada, vilosa a glabrescente em ambas as faces; face adaxial verde, face abaxial verde-clara a vinácea; venação actinódroma, 5-7(8) nervuras na base. Cimeiras 2,513,7 cm compr., 5-10 flores, 2 ou 3 nós; brácteas de primeira ordem $1,5-4 \times 0,6-2 \mathrm{~mm}$, ovadas, caducas. Flores estaminadas sem bractéolas; tépalas 4 , alvas a róseas, as externas maiores, orbiculares a elípticas, face abaxial glabra, as internas oblanceoladas, face abaxial glabra; estames 16-36, anteras rimosas, conectivos proeminentes. Flores pistiladas com 3 bractéolas ovadas a espatuladas, persistentes; tépalas 5, alvas a róseas, tamanhos semelhantes, elípticas a obovadas, face abaxial glabra; ovário com placenta partida. Cápsulas 1-2 × 1,6-4 cm, sem tricomas glandulares microscópicos, glabrescentes; alas 3, desiguais, a maior $1-2,6 \mathrm{~cm}$ larg., ápice agudo, as menores $2-5 \mathrm{~mm}$ larg., arredondadas. Sementes fusiformes.

Ocorre do sul do México até a Argentina (Smith \& Smith 1971; Jacques \& Mamede 2005). No Brasil, é encontrada nas regiões Sul, Sudeste e Centro-Oeste, além dos estados da Bahia, Pernambuco e Roraima (Jacques 2015). D6, E8, E9, F6, F8, G8, H8, I8, J8: Floresta ombrófila densa montana, cerrado de altitude, capoeira e campo rupestre. Ocorre em orlas de mata, matas ciliares e ilhas de vegetação nos rios, geralmente em solos úmidos ou alagados; é encontrada também em áreas com perturbação antrópica. Floresce e frutifica durante o ano todo.

Material selecionado - Almadina, Serra do Corcovado, 144ㄴ'21"S, 39³6'12"W, 650-900 m s.n.m., 12 ago. 2007 (fl., fr.), D. Cardoso et al. 2143 (CEPEC); Amargosa, Serra do Timbó, nas proximidades da barragem do Timbó, 13ํ' $4^{\circ} 57^{\prime \prime} \mathrm{S}, 39^{\circ} 39^{\prime} 15^{\prime \prime} \mathrm{W}, 21$ maio 2013 (est.), B.S. Gregório 244 (HUEFS); Anguera, 1209'57"S, 39²12'43"W, 10 jan. 2012 (bot., fl., fr.), B.S. Gregório 194 (HUEFS); Cachoeira, Ipuaçu, vale dos Rios Paraguaçu e Jacuípe, $12^{\circ} 32^{\prime} \mathrm{S}, 39^{\circ} 05^{\prime} \mathrm{W}, 40-120$ m s.n.m., dez. 1980 (fl.), Grupo Pedra do Cavalo 984 (ALCB, BAH, CEPEC, HRB, HUEFS); Camacan, Reserva Particular do Patrimônio Natural Serra Bonita, $15^{\circ} 23^{\prime} 30^{\prime \prime S}, 39^{\circ} 33^{\prime} 55^{\prime \prime W}, 835$ m s.n.m., 30 out. 2005 (fl.), A.M. Amorim et al. 5453 (CEPEC, HUEFS, RB); Cravolândia, $5 \mathrm{~km}$ ao sul do povoado de Três Braços, 13⒉1'31"S, 3948'54"W, 29 maio 1994 (fl., fr.), E. Melo \& F. França 1044 (CEPEC, HUEFS); Feira de Santana, rodovia BR-116, entre o retorno do bairro Cidade Nova e a cidade de Feira de Santana, $12^{\circ} 15^{\prime}$ S, 38 $58^{\circ}$ W, 7 set. 1983 (fl., fr.), L.R. Noblick 2731 (HUEFS, SPF); Guaratinga, córrego Jacutinga, 16035'02"S, 39 46'58"W, 23 abr. 2009 (fl.), L. Kollmann et al. 11570 (MBML); Ilhéus, $14^{\circ} 51^{\prime} \mathrm{S}, 39^{\circ} 02^{\prime} \mathrm{W}, 29$ nov. 1981 (fl., fr.), G.P. Lewis \& A.M. Carvalho 706 (CEPEC); Itabuna, $14^{\circ} 47^{\prime} 08^{\prime \prime} \mathrm{S}, 39^{\circ} 16^{\prime} 49^{\prime \prime} \mathrm{W}, 26$ jun. 1965 (fl.), R.P. Belém \& A.M. Aguiar 1250 (CEPEC, UB); Itamaraju, 16 $59^{\prime} 23^{\prime \prime S}, 39^{\circ} 34^{\prime} 40^{\prime \prime} \mathrm{W}, 8$ dez. 2010 (fl.), L. Kollmann et al. 12121 (MBML); Morro do Chapéu, Cachoeira do Ventura, $11^{\circ} 41^{\prime} 4^{\prime \prime} \mathrm{S}, 41^{\circ} 1^{\prime} 38^{\prime \prime} \mathrm{W}, 820 \mathrm{~m}$ s.n.m., 8 ago. 2003 (fl.), J.O.V. Nascimento et al. 39 (HUEFS); 


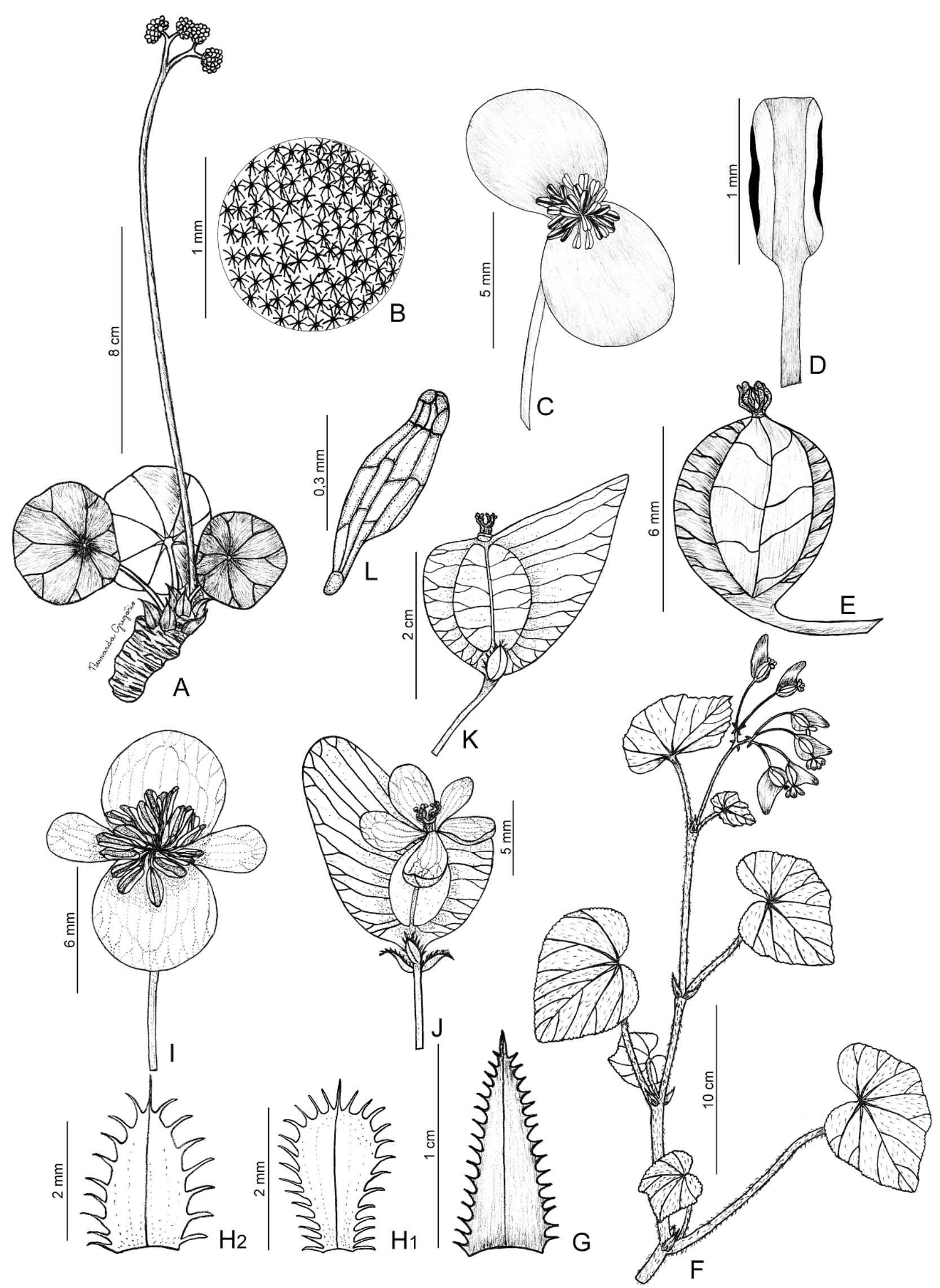

Figura 11. A-E. Begonia fellereriana: A- ramo florido; B- detalhe do indumento da lâmina foliar; C- flor estaminada; D- estame; E- cápsula. F-L. B. fischeri: F- ramo florido; G- estípula; H1, 2- bractéolas da flor estaminada; I- flor estaminada; J- flor pistilada; K- cápsula; L- semente. (A-E- Giulietti 1865; F, G, I-L- Gregório 194; H1, 2- Harley 25323). 


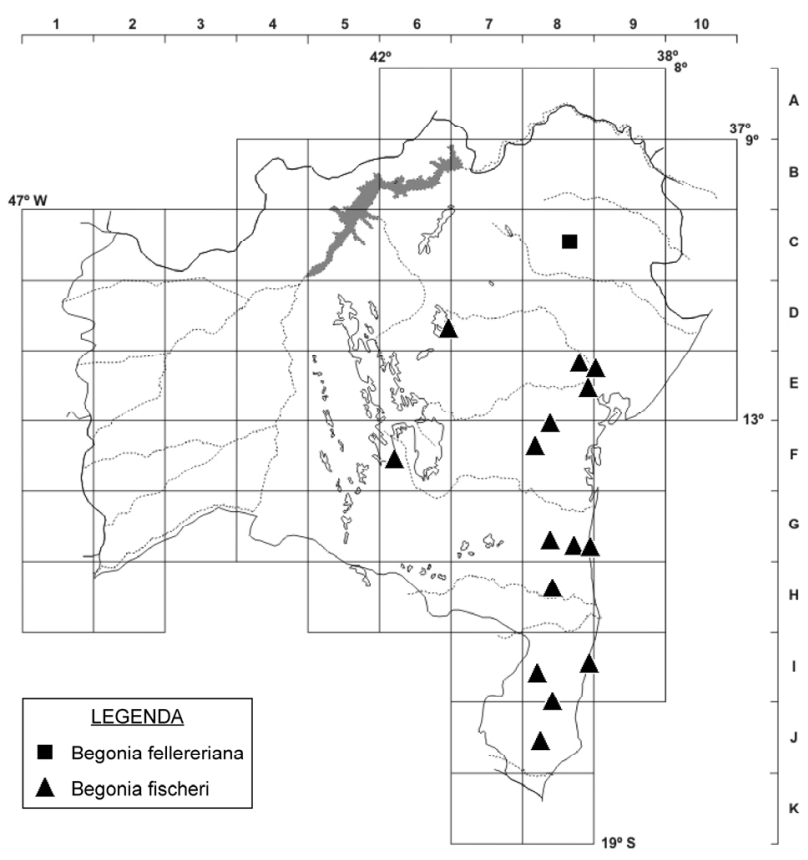

Figura 12. Mapa de distribuição de Begonia fellereriana e B. fischeri no estado da Bahia.

Porto Seguro, Km 16 de Porto Seguro-Eunápolis, vale do Rio Buranhém, 16²6'59"S, 3903'53"W, 17 jul. 1981 (fl., fr.), H.S. Brito \& S.G. Vinha 38 (CEPEC); Rio de Contas, entre as fazenda

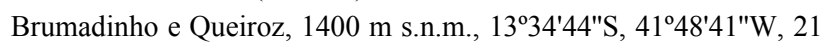
fev. 1987 (fr.), R.M. Harley et al. 24631 (HUEFS, IPA, K, MBM, $\mathrm{SPF})$; Teixeira de Freitas, Km 11 da BR-101 Teixeira de FreitasRancho Alegre, 17 ago. 1972 (fl., fr.), T.S. Santos 2400 (CEPEC).

Begonia fischeri caracteriza-se pelo indumento viloso em toda a planta, exceto nas flores, pelas lâminas foliares ovadas e pelo ápice agudo da ala maior das cápsulas. Begonia fischeri é muito parecida com $B$. hirtella e, por isso, são comumente confundidas; $B$. fischeri diferencia-se de $B$. hirtella pelas sementes fusiformes (vs. oblongas).

13. Begonia fruticosa A.DC. in Martius, Fl. Bras. 4: 377. 1861.

Figuras $13 \mathrm{~A}-\mathrm{E}$ e 14.

Trepadeiras, 3-15 m compr., glabriúsculas, tricomas simples e glandulares microscópicos. Caule escandente, glabrescente; entrenós 0,7-5,5 cm compr. Estípulas $0,5-1,2 \mathrm{~cm} \times 2-4 \mathrm{~mm}$, lanceoladas, ápice apiculado, margem inteira, carenadas, apressas, persistentes. Folhas com pecíolo 2-7(12) mm compr., piloso; lâmina 4,5-10,2 × 1,5-3,5 cm, inteira, levemente assimétrica, basifixa, papirácea, elíptica a obovada, ápice acuminado, base levemente oblíqua, margem serreada, ciliada, esparsamente pilosa a glabra em ambas as faces; face adaxial verde, face abaxial verde-clara a vinácea; venação craspedódroma. Cimeiras 3-7,8 cm compr., 40-100 flores, 3-5 nós; brácteas de primeira ordem 1,5-4,5 × 1-2 mm, lanceoladas, persistentes. Flores estaminadas sem bractéolas; tépalas 4, alvas, as externas maiores, obovadas, côncavas, face abaxial com tricomas glandulares microscópicos, as internas oblanceoladas, côncavas, face abaxial com tricomas glandulares microscópicos; estames 16-32, anteras rimosas, conectivos proeminentes. Flores pistiladas com 2 bracteólas lanceoladas, persistentes; tépalas 5, alvas, duas maiores, lanceoladas, face abaxial com tricomas glandulares microscópicos; ovário com placenta inteira. Cápsulas 6-12 × 5-12 $\mathrm{mm}$, com tricomas glandulares microscópicos a glabras; alas 3, iguais, 1,5-3,5 mm larg., ápice arredondado. Sementes lineares.

Ocorre na Argentina e no Brasil (Smith et al. 1986). No Brasil, é encontrada nas Regiões Sul e Sudeste e no estado da Bahia (Jacques 2015). F8, G8, H8: Floresta ombrófila densa montana e submontana. Ocorre sobre troncos de árvores, em formações primárias ou em matas perturbadas, geralmente em margens de rios e em encostas de morros. Floresce de maio a novembro e frutifica em maio, junho e novembro.

Material selecionado - Almadina, Serra do Corcovado, 14ㄴ2'21"S, 39³6'12"W, 650-750 m s.n.m., 21 jun. 2005 (bot.), $P$. Fiaschi et al. 2937 (CEPEC); Arataca, Serra do Peito de Moça,

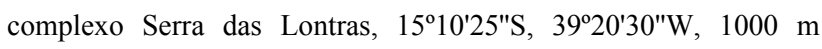
s.n.m., 12 out. 2005 (fl.), A.M. Amorim et al. 5265 (CEPEC, RB); Barro Preto, Serra da Pedra Lascada, $14^{\circ} 46^{\prime} 13^{\prime \prime S}, 39^{\circ} 12^{\prime} 10^{\prime \prime} \mathrm{W}$, 600-900 m s.n.m., 10 abr. 2012 (est.), B.S. Gregório 198 (HUEFS); Camacan, Reserva Particular do Patrimônio Natural Serra Bonita, Trilha da Bromélia, 15²3'30"S, 39³3'55"W, 12 fev. 2013 (est.), B.S. Gregório 222 (HUEFS); Jaguaquara, distrito de Baixão do

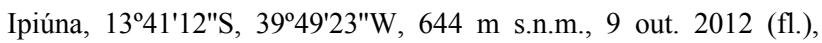
D.C. Zappi et al. 3392 (RB); Wenceslau Guimarães, Estação Ecológica Estadual de Wenceslau Guimarães, Trilha da Petioba, 133' $49^{\prime \prime S}, 39^{\circ} 42^{\prime} 17^{\prime \prime W}$, 450-650 m s.n.m., 24 maio 2013 (est.), B.S. Gregório 251 (CEPEC, HUEFS).

Material adicional - BRASIL. RIO DE JANEIRO: s.d. (fl.), F. Sellow s.n. (B 100244013 [foto]).

Begonia fruticosa caracteriza-se pelo hábito trepador, lâminas foliares elípticas a obovadas, levemente assimétricas, margem serreada, venação craspedódroma, pecíolo curto, inflorescências pequenas e cápsulas com alas semelhantes. Assemelha-se a $B$. besleriifolia pelas estípulas lanceoladas, pecíolo curto, forma das lâminas foliares e flores estaminadas com tépalas côncavas. Begonia fruticosa pode ser diferenciada de $B$. besleriifolia pelas estípulas persistentes (vs. caducas), lâminas foliares com margem serreada (vs. inteira a levemente ondulada) e cápsulas com alas iguais (vs. cápsulas com uma ala maior).

14. Begonia glabra Aubl., Hist. P1. Guiane 2: 916; tab. 349. 1775.

= Begonia smilacina A.DC., Ann. Sci. Nat., Bot., sér. 4, 11: 137. 1859. Syn. nov.

Figuras $13 \mathrm{~F}-\mathrm{J}$ e 14.

Trepadeiras, 2-15 m compr., glabriúsculas a glabras, esparsos tricomas simples e glandulares microscópicos. Caule escandente, glabriúsculo; entrenós 2-12 cm compr. Estípulas 1-2,3 × 0,5-1,4 $\mathrm{cm}$, ovadas, ápice apiculado, margem inteira, 


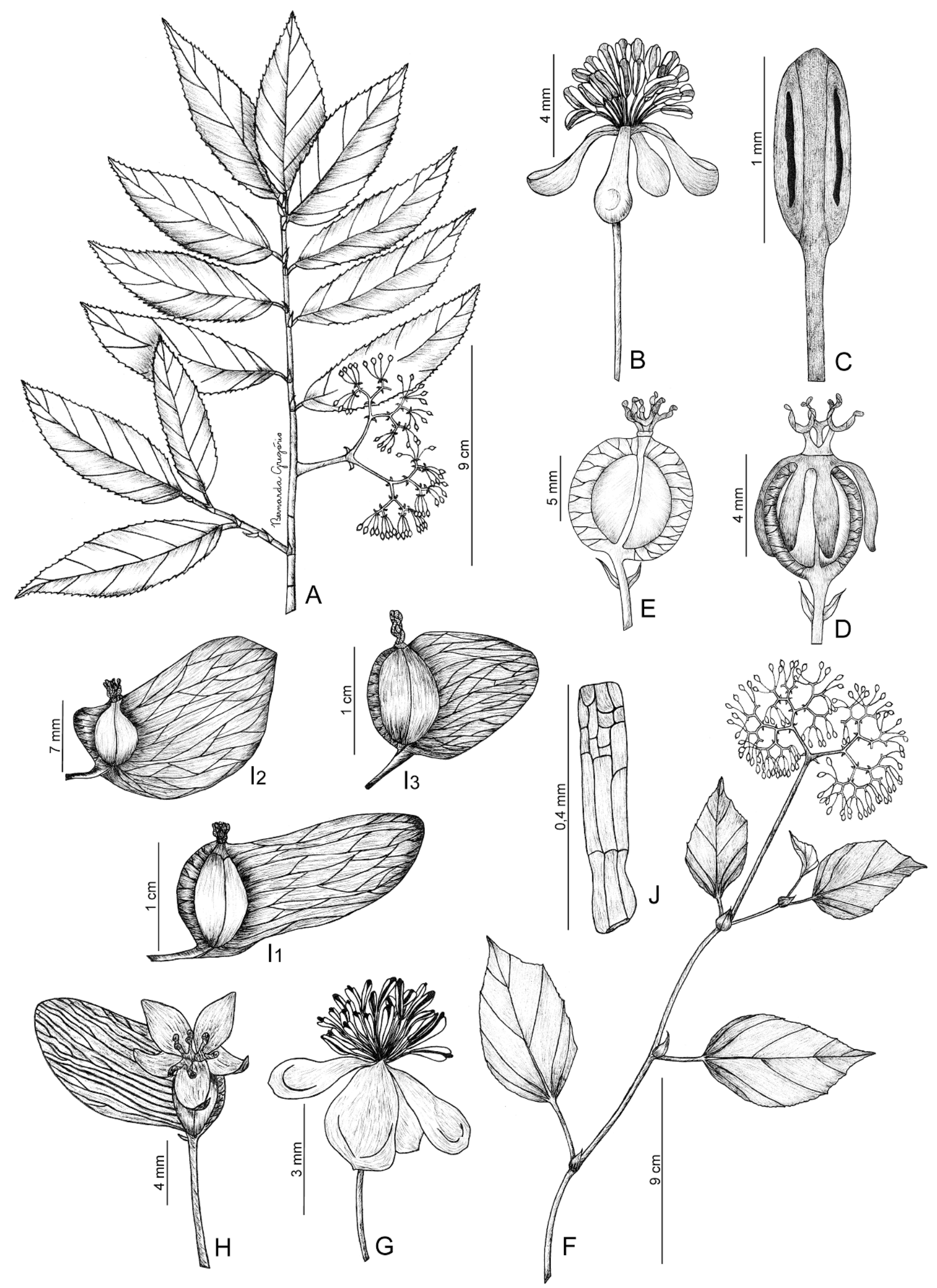

Figura 13. A-E. Begonia fruticosa: A- ramo florido; B- flor estaminada; C- estame; D- flor pistilada; E- cápsula. F-J. B. glabra: F- ramo florido; G- flor estaminada; H- flor pistilada; I1-3- cápsula; J- semente. (A-C- Amorim 4229; D, E- Fiaschi 1806; F, G- Lopes 331; H- Carvalho 4610; I1- Jardim 1130; I2- Profice 114; I3, J- Alves 1995). 
carenadas, apressas, persistentes. Folhas com pecíolo 1,1-7,5(-9) cm compr., glabriúsculo; lâmina 5-14($18) \times 2,5-11(-13) \mathrm{cm}$, inteira, assimétrica, basifixa, papirácea, obovada, ovada ou elíptica, ápice acuminado, base obtusa a arredondada, margem irregularmente crenada a denticulada, glabriúscula a glabra em ambas as faces; face adaxial verde, face abaxial verde-pálida ou vinácea; venação actinódroma, 5 nervuras na base. Cimeiras 13,5-19(-35) cm compr., 50-100 flores, 6-8 nós; brácteas de primeira ordem 5$9 \times 2-4 \mathrm{~mm}$, lanceoladas, persistentes. Flores estaminadas sem bractéolas; tépalas 4, alvas, as externas maiores, obovadas a raramente elípticas, côncavas, face abaxial com tricomas glandulares microscópicos, as internas oblanceoladas, côncavas, face abaxial glabra; estames 36-60, anteras rimosas, conectivos proeminentes. Flores pistiladas com 2 bractéolas estreitamente lanceoladas, persistentes; tépalas 5, alvas, sendo três maiores, elípticas, face abaxial glabra; ovário com placenta inteira. Cápsulas 0,5-1,4 $\times$ 1,1-2,6 cm, com esparsos tricomas glandulares microscópicos; alas 3, desiguais, a maior 0,6-1,8 cm larg., ápice arredondado, obtuso a agudo, as menores 0,5-2 $\mathrm{mm}$ larg., arredondadas. Sementes lineares a elípticas.

Ocorre em Belize, Bolívia, Brasil, Colômbia, Costa Rica, Cuba, Equador, Guiana, Guiana Francesa, Guatemala, Honduras, Jamaica, México, Nicarágua, Panamá, Peru, Suriname, Trindad e Tobago e Venezuela. No Brasil, é encontrada no Acre, Amapá, Amazonas, Bahia, Espírito Santo, Pará e Roraima (Kollmann 2012). E8, F8, G7, G8, H8: Floresta ombrófila densa montana e submontana. Ocorre sobre árvores no interior da mata preservada ou parcialmente perturbada. A espécie é encontrada em plantação de cacau e em bordas de trilhas. Floresce e frutifica praticamente durante todo o ano.

Material selecionado - Almadina, Serra do Corcovado, 14²42'21"S, 39³6'12"W, 11 abr. 2012 (fr.), B.S. Gregório 204 (CEPEC, HUEFS); Amargosa, Serra do Timbó, com acesso pelo Morro Pelado, $13^{\circ} 06^{\prime} 09^{\prime \prime S}, 39^{\circ} 40^{\prime} 39^{\prime \prime} \mathrm{W}, 750-835 \mathrm{~m}$ s.n.m., 18 nov. 2007 (fl.), A.M. Amorim et al. 7033 (CEPEC); Apuarema, Concessão da Rio Tinto, 1353'31"S, 39²41'11"W, 698 m s.n.m., 21 nov. 2013 (bot.), L.Y.S. Aona 3314 (RB); Barro Preto, Serra da Pedra Lascada, 1446'13"S, 39³2'10"W, 10 abr. 2012 (fl.), B.S Gregório 200 (CEPEC, HUEFS); Boa Nova, fazenda São José, 14²3'74"S, 408'76"W, 850 m s.n.m., 7 jan. 2001 (fl., fr.), A.M. Amorim et al. 3595 (CEPEC); Igrapiúna, sítio Rodotec, caminho para a comunidade do Forte, $13^{\circ} 49^{\prime} \mathrm{S}, 39^{\circ} 08^{\prime} \mathrm{W}, 21 \mathrm{dez} .2003$ (fr.), R.B. Bispo 6 (ALCB); Ilhéus, Mata da Esperança, entrada pelo banco da Vitória, ca. $3,5 \mathrm{~km}$ à nordeste da sede, 14\%46'38"S, 3905'28"W, 25 ago. 1994 (fl.), A.M. Carvalho et al. 4610 (CEPEC); ib., Almada, s.d. (fl., fr.), L. Riedel 671 (holótipo de $B$. smilacina: G-DC [foto], isótipo: $\mathrm{K}$ [foto]); Itacaré, estrada Itacaré-

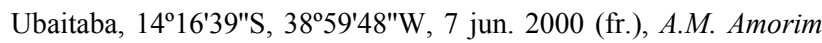
et al. 3425 (CEPEC, RB); Ituberá, assentamento Limoeiro, proximidades da sede Patioba, 13057'13"S, 39 $15^{\prime} 59^{\prime \prime} \mathrm{W}, 16 \mathrm{dez}$. 2001 (fl., fr.), D.M. Loureiro 424 (ALCB); Santa Teresinha, Serra da Jiboia, à margem da estrada da Serra da Pioneira, $12^{\circ} 50^{\prime} \mathrm{S}$,

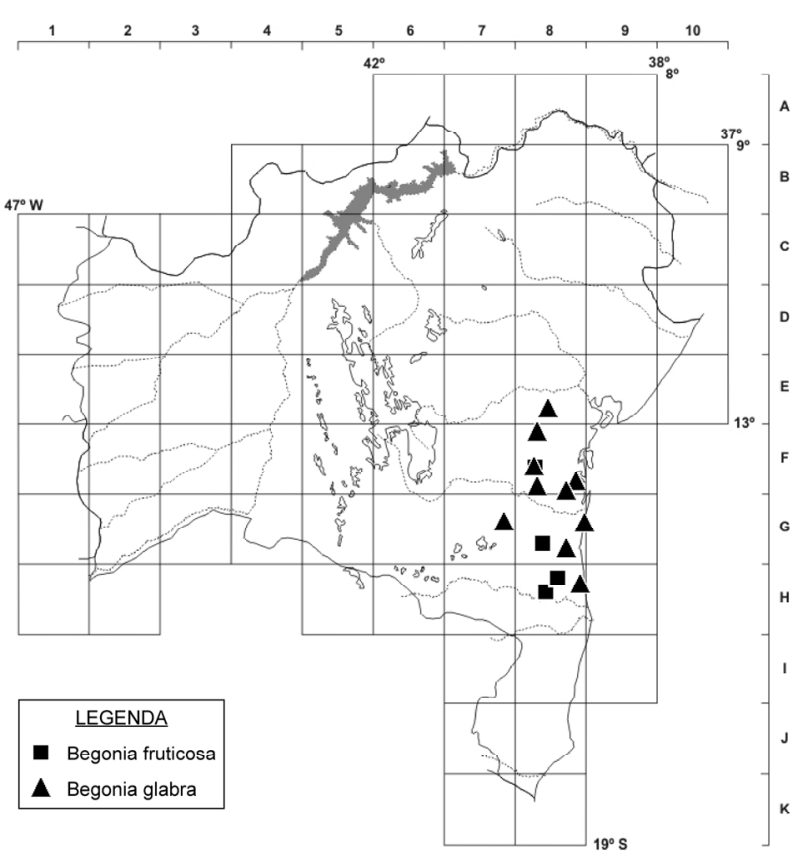

Figura 14. Mapa de distribuição de Begonia fruticosa e B. glabra no estado da Bahia.

39² $8^{\prime} \mathrm{W}, 14$ fev. 2001 (fl.), A.A. Ribeiro-Filho 199 (HUEFS); Ubaitaba, rodovia Banco Central-Ubaitaba, $14^{\circ} 18^{\prime} 45^{\prime \prime} \mathrm{S}$, 39¹9'24"W, 21 abr. 1971 (bot., fl.), R.S. Pinheiro 1224 (CEPEC); Una, Reserva Biológica do Mico-leão (IBAMA), 1509' 25 jan. 1996 (est.), A.M. Amorim et al. 1905 (CEPEC); Uruçuca, distrito de Serra Grande, fazenda Lagoa do Conjunto fazenda Santa Cruz, 14 $25^{\circ} \mathrm{S}, 39^{\circ} 01^{\prime} \mathrm{W}, 25$ jan. 1995 (est.), A.M. Amorim et al. 1940 (CEPEC); Wenceslau Guimarães, Estação Ecológica Estadual de Wenceslau Guimarães, Trilha da Petioba, 13³4'49"S, 3942'17"W, 24 maio 2013 (est.), B.S. Gregório 252 (CEPEC).

Material adicional - BRASIL. AMAZONAS: Santo Antônio do Içá, 15 nov. 1906 (fl.), A. Ducke 7666 (HB). COSTA RICA. $10^{\circ} 10^{\prime} \mathrm{N}, 84^{\circ} 00^{\prime \prime} \mathrm{W}, 100$ m s.n.m., 14 maio 2002 (fr.), L. Landrum et al. 10219 (ASU). GUIANA FRANCESA. 1775 (fl. fr.), J.B.C.F. Aublet s.n. (holótipo de B. glabra: BM 1008462 [foto]). JАMAICA. s.d. (fr.), H. Sloane s.n. (BM 589732 [foto]); MÉXICO. s.d. (est.), M. Sessé \& J.M. Mociño 5412 (MA [foto]).

Na descrição original, $B$. glabra foi caracterizada pelos ramos flexuosos e glabros, folhas com lâminas ovadas, acuminadas e base obtusa a subcordada, margem irregularmente crenado-dentada; estípulas largamente lanceoladas; flores estaminadas com sépalas obovado-oblongas; flores pistiladas com tépalas elípticas, sendo as duas externas menores (Aublet 1775). Begonia smilacina, descrita para a Bahia, foi considerada distinta desta espécie pelas lâminas foliares obovadas e flores estaminadas com "sépalas" ovadas (Candolle 1859, 1861). Contudo, verificou-se uma sobreposição das características utilizadas na separação das duas espécies, sendo possível encontrar folhas ovadas, obovadas ou elípticas na mesma exsicata. A base foliar também apresenta ampla variação, assim como as tépalas das flores estaminadas, que variam de obovada a elíptica, e a maior ala da cápsula, que pode ser ovada ou oblonga. 
Candolle (1861) relatou semelhanças entre as duas espécies, porém considerou $B$. glabra restrita às Ilhas Caribenhas, Peru e Costa Rica, apesar da espécie também ocorrer no Brasil, especialmente na Floresta Amazônica.

Após a análise de diversos exemplares de B. glabra, incluindo fotos dos materiais-tipo, ao longo de sua distribuição geográfica, desde a América Central até o Brasil, na região da Floresta Amazônica e da Mata Atlântica do sul da Bahia, verificou-se o polimorfismo de B. glabra em relação às folhas, flores estaminadas e frutos. Assim, confirmou-se que B. glabra é uma espécie com diferentes expressões fenotípicas ao longo de sua distribuição e, por isso, propõe-se aqui a sinonimização de $B$. smilacina em B. glabra.

\section{Begonia goldingiana L.Kollmann \& A.P.Fontana,} Candollea 65(2): 186. 2010.

Figuras $15 \mathrm{~A}-\mathrm{E}$ e 16.

Ervas ou subarbustos, 0,8-1,2 m alt., lanuginosos, tricomas estrelados. Caule ereto, glabrescente; entrenós 0,5-8 cm compr. Estípulas 2,5-3,5 cm $\times 5-9$ $\mathrm{mm}$, lanceoladas, ápice acuminado, margem inteira, apressas, caducas. Folhas com pecíolo 4,2-17,5 cm compr., glabriúsculo; lâmina 9-18,8 × 6-13 cm, inteira, assimétrica, peltada, carnosa, suborbicular a elíptica, ápice obtuso, margem levemente ondulada, glabrescente na face adaxial, lanuginosa na abaxial; face adaxial verde, face abaxial verde-clara; venação actinódroma, 9-11 nervuras a partir do ápice do pecíolo. Cimeiras 23,5-68 cm compr., 30-80 flores, 4-6 nós; brácteas de primeira ordem 3,5-16 × 2,7-7 $\mathrm{mm}$, ovadas, caducas. Flores estaminadas sem bractéolas; tépalas 4, alvas, as externas maiores, obovadas a ovadas, côncavas, face abaxial pubescente, as internas oblanceoladas, côncavas, face abaxial glabra; estames 20-56, anteras rimosas, conectivos proeminentes. Flores pistiladas com 2 bractéolas ovadas a orbiculares, caducas; tépalas 5, alvas, sendo três maiores, obovadas a elípticas, face abaxial glabrescente; ovário com placenta inteira. Cápsulas 0,7-1,1 × 0,9-1,8 cm, pubescentes, sem tricomas glandulares microscópicos; alas 3, desiguais, a maior 5-9,5 mm larg., ápice arredondado a obtuso, as menores 2-4,5 $\mathrm{mm}$ larg., arredondadas. Sementes oblongas.

Endêmica do estado da Bahia (Kollmann \& Fontana 2010), foi registrada até o momento em Guaratinga e Itamaraju. I8, J8: Floresta ombrófila densa montana e submontana. Cresce sobre rochas, à meia sombra ou sob o sol, em camada leve de húmus. Floresce em fevereiro, abril, setembro e dezembro; frutifica em outubro e dezembro.

Material selecionado - Guaratinga, córrego Jacutinga, 16038'26"S, 3947'54,4"W, 369 m s.n.m., 23 abr. 2009 (fl., fr.), $L$. Kollmann et al. 11571 (holótipo de B. goldingiana: MBML, isótipos: CEPEC, RB); Itamaraju, fazenda Novo Pau-Brasil, morro Pescoço, 16059'43"S, 39³5'26"W, 11 maio 2013 (est.), B.S. Gregório 241 (HUEFS).
Begonia goldingiana é uma planta rupícola caracterizada pelo indumento lanuginoso, constituído por tricomas estrelados, lâminas foliares peltadas, suborbiculares a elípticas, com ápice obtuso. Assemelha-se a $B$. fellereriana e $B$. umbraculifera pelos tricomas estrelados e lâminas foliares peltadas. No entanto, difere de $B$. fellereriana pelo caule ereto (vs. prostrado ou decumbente), flores estaminadas com 4 tépalas (vs. 2) e bractéolas das flores pistiladas ovadas a orbiculares (vs. estreitamente elípticas). Difere de $B$. umbraculifera pelo indumento lanuginoso (vs. glabriúsculo a glabro), flores estaminadas com 4 tépalas (vs. 2) e bractéolas das flores pistiladas ovadas a orbiculares (vs. estreitamente elípticas).

16. Begonia grisea A.DC., Ann. Sci. Nat., Bot., sér. 4, 11: 138. 1859

Figuras 15F-K e 16.

Ervas ou subarbustos, 0,3-3 m alt., pubescentes a tomentosos, tricomas estrelados. Caule ereto, glabrescente; entrenós 0,2-5(-7,7) cm compr. Estípulas $1-3,3 \times 0,6-2,5 \mathrm{~cm}$, triangulares, ápice apiculado, margem inteira, carenadas, apressas, geralmente caducas. Folhas com pecíolo 1,5-13,5(17,5) cm compr., tomentoso a glabrescente; lâmina 3,5-13,5 × 5,6-16 cm, inteira, levemente assimétrica, basifixa, coriácea ou crassa, arredondada a transversalmente elíptica, ápice arredondado, raramente obtuso, base cordada, margem inteira a irregularmente denticulada, tomentosa em ambas as faces, mais densamente na face abaxial, glabrescente na face adaxial; face adaxial verde, face abaxial verdepálida; venação actinódroma, 6-10 nervuras na base. Cimeiras 12,9-75,5 cm compr., 30-200 flores, 3-8 nós; brácteas de primeira ordem 5-8 × 2-4 mm, obovadas, caducas. Flores estaminadas sem bractéolas; tépalas 2, alvas, largamente ovadas a orbiculares, face abaxial glabrescente; estames 12-28, anteras rimosas, conectivos proeminentes. Flores pistiladas com 2 bractéolas estreitamente elípticas a oblongas, caducas; tépalas 5(6), alvas a róseas, sendo três ligeiramente maiores, elípticas a ovadas, face abaxial glabrescente; ovário com placenta inteira. Cápsulas $0,7-1,6 \times 0,8-1,7 \mathrm{~cm}$, pilosas a glabrescentes, sem tricomas glandulares microscópicos; alas 3, desiguais, a maior 3-6 mm larg., ápice arredondado a agudo, as menores 1-4 mm larg., arredondadas. Sementes oblongas.

Endêmica do Brasil, é encontrada em Alagoas, Bahia, Minas Gerais e Pernambuco (Jacques 2015). C6, C7, D6, D7, E6, E7, F5, F6, F8, G8, H7: Preferencialmente em campo rupestre, mas também em mata de grotão, mata ciliar, mata de encosta, cerrado, campo sujo, campos gerais, carrasco, caatinga, menos frequentemente em floresta ombrófila densa montana. Cresce exposta ao sol, em encostas de morros, sobre ou entre afloramentos rochosos de arenitos, em solos litólicos ou hidromórficos. Floresce e frutifica durante o ano todo. 


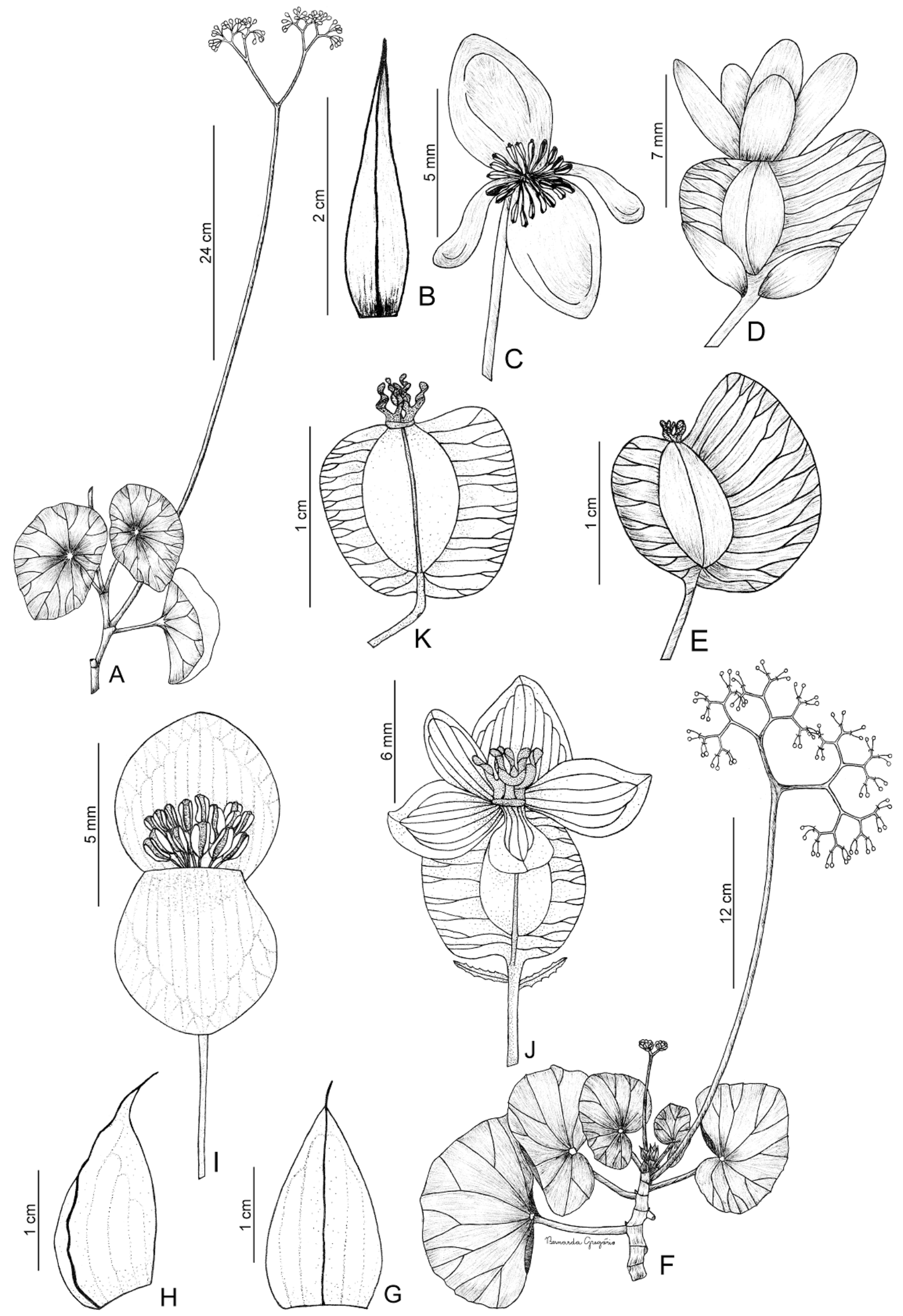

Figura 15. A-E. Begonia goldingiana: A- ramo florido; B- estípula; C- flor estaminada; D- flor pistilada; E- cápsula. F-K. B. grisea: F- ramo florido; G- visão dorsal da estípula; H- visão dorso-lateral da estípula; I- flor estaminada; J- flor pistilada; K- cápsula. (A-C- Kollmmann 12110; D, E- Kollmann 11571; F-I- Novais 37; J- Nonato 1000; K- Harley 25796). 


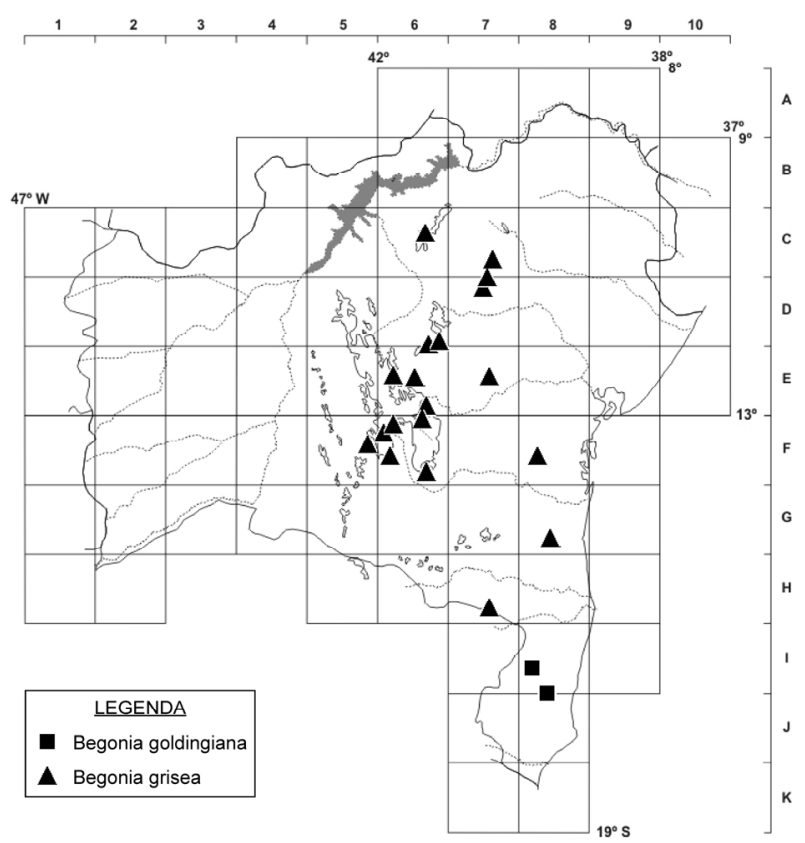

Figura 16. Mapa de distribuição de Begonia goldingiana e B. grisea no estado da Bahia.

Material selecionado - Abaíra, Campo do Cigano, $13^{\circ} 15^{\prime} \mathrm{S}$, 41 ${ }^{\circ} 55^{\prime} \mathrm{W}, 1700-1800$ m s.n.m., 26 fev. 1992 (fl.), P.T. Sano \& T. Laessoe H 52338 (CEPEC, HUEFS, K, SPF); Almadina, Serra do Corcovado, 14 $42^{\prime} 21^{\prime \prime S}, 39^{\circ} 36^{\prime} 12^{\prime \prime} \mathrm{W}, 11$ abr. 2012 (fr.), B.S. Gregório 202 (CEPEC, HUEFS); Andaraí, estrada para Mucugê, curva da estrada, 12 $57^{\prime} 24 " \mathrm{~S}, 41^{\circ} 19^{\prime} 09^{\prime \prime W}, 1163 \mathrm{~m}$ s.n.m., 24 out. 2000 (fl.), E.R. Souza et al. 60 (HUEFS); Barro Preto, Serra da Pedra Lascada, 1446'19"S, 39³2'33"W, 556-860 m s.n.m., 16 jan. 2007 (fr.), A.P. Fontana et al. 2614 (CEPEC); Bonito, estrada para Bonito, na beira da pista, $11^{\circ} 58^{\prime} 10^{\prime \prime} \mathrm{S}, 41^{\circ} 15^{\prime} 57^{\prime \prime} \mathrm{W}, 6$ nov. 2002 (fl.), M.E.R. Junqueira et al. 136 (HUEFS, SPF); Érico Cardoso (antigo Água Quente), arredores do Pico das Almas, 13⒉ $5^{\prime} 04^{\prime \prime S}$, 42 $08^{\prime} 25^{\prime \prime W}, 26$ mar. 1980 (fl.), S. Mori \& F. Benton 13614 (CEPEC); Ituaçu, 134' $48^{\prime \prime} \mathrm{S}, 4^{\circ} 17^{\prime} 48^{\prime \prime} \mathrm{W}, 19$ ago. 1988 (fl.), $U$. Eggli 1205 (CEPEC); Jacobina, Monte Taboa, ca. $2 \mathrm{~km}$ da cidade,

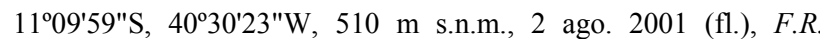
Nonato et al. PCD 839 (CEPEC, HUEFS); Lençóis, Parque

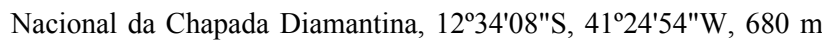
s.n.m., 15 jun. 2005 (fl.), A. Moraes et al. 10 (HUEFS); Macarani, 1546'19"S, 40²4'50"W, 560-600 m s.n.m., 17 ago. 2001 (fl.), A.M. Carvalho et al. 7021 (HUEFS); Maracás, fazenda Cana Brava, $12^{\circ} 26^{\prime} \mathrm{S}, 40^{\circ} 25^{\prime} \mathrm{W}, 900-1000 \mathrm{~m}$ s.n.m., 31 ago. 1996 (fl.), R.M. Harley et al. 28234 (HUEFS, MBM, SP, SPF); Morro do Chapéu, Serra do Tocaia, $11^{\circ} 33^{\prime} 00^{\prime \prime} \mathrm{S}, 41^{\circ} 09^{\prime} 22^{\prime \prime W}, 30$ jan. 2013 (fl., fr.), B.S. Gregório 214 (HUEFS); Mucugê, Parque Municipal de Mucugê, próximo à sede, $13^{\circ} 00^{\prime} 19^{\prime \prime} \mathrm{S}, 4^{\circ} 22^{\prime} 15^{\prime \prime} \mathrm{W}, 23$ maio 2009 (fl.), B.S. Gregório 121 (BRBA); Palmeiras, Morro do Pai Inácio,

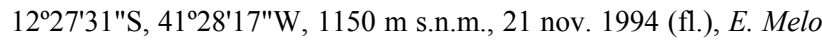
et al. PCD 1206 (HUEFS); Piatã, entrada para Inúbia, próximo à

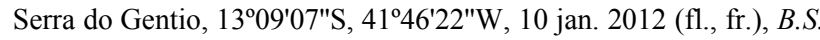
Gregório 196 (HUEFS); Pindobaçu, 1044'30"S, 40²1'39"W, 6 dez. 2003 (fl.), A.M. Miranda et al. 4309 (HST, HUEFS); Rio de

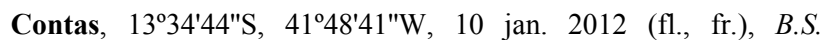
Gregório 195 (HUEFS); Saúde, Paulista, cachoeira do Rio das Pedras, $1,5 \mathrm{~km}$ do povoado, $11^{\circ} 00^{\prime} 24^{\prime \prime S}, 40^{\circ} 26^{\prime} 48^{\prime \prime} \mathrm{W}, 500 \mathrm{~m}$ s.n.m.,
12 ago. 1999 (fl.), E.B. Miranda et al. 110 (HST, HUEFS); Seabra,

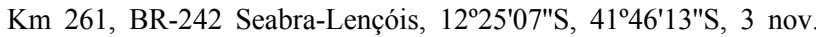
1978 (fl.), A. Allem \& G. Vieira 1768 (CEN, RB); Umburanas, Serra do Curral Feio (localmente referida como Serra da Empreitada), $10^{\circ} 22^{\prime} \mathrm{S}, 41^{\circ} 19^{\prime} \mathrm{W}, 1000-1200$ m s.n.m., 9 abr. 1999 (fl.), L.P. Queiroz et al. 5167 (HUEFS); Wenceslau Guimarães, Estação Estadual Nova Esperança, trilha para o Pico do Urubu, $13^{\circ} 34^{\prime} 55^{\prime \prime S}, 39^{\circ} 43^{\prime} 23^{\prime \prime W}, 700-814$ m s.n.m., 4 maio 2007 (fr.), J.G. Jardim et al. 5031 (CEPEC).

Material adicional - BRASIL. MINAS GERAIS: s.d. (fl.), $A$. Saint-Hilaire 2027 (holótipo de B. grisea: P [foto]).

Begonia grisea caracteriza-se por apresentar caule com cicatrizes conspícuas das folhas mais velhas, estípulas geralmente caducas, lâminas foliares basifixas, transversalmente elípticas a arredondadas, com indumento pubescente a tomentoso constituído por tricomas estrelados, brancos ou ferrugíneos, e pelas flores estaminadas com duas tépalas. Contudo, em dois espécimes (Fiaschi 2398 e Gregório 195) foram encontradas algumas flores com quatro tépalas. Essa variação também foi encontrada em dois espécimes de B. grisea no estado de Minas Gerais (Feliciano 2009). Além disso, foram encontrados espécimes com folhas semipeltadas a peltadas nos municípios de Piatã e Santa Terezinha, o que não é incomum em Begonia (Sosef 1994). Contudo, dentre as Begoniaceae da Bahia, essa particularidade só foi observada em $B$. grisea.

Begonia grisea possui semelhanças morfológicas com B. pernambucensis, da qual pode ser diferenciada pelo caule ereto (vs. prostrado ou decumbente), estípulas geralmente caducas (vs. persistentes) e número de tépalas das flores estaminadas (2 vs. 4).

17. Begonia hirtella Link, Enum. Hort. Berol. Alt. 2: 396. 1822.

Figuras 17A-F e 18.

Ervas, 7-40 cm alt., vilosas, tricomas simples e glandulares microscópicos. Caule ereto, viloso a glabrescente; entrenós $(0,5) 1-7,7 \mathrm{~cm}$ compr. Estípulas $0,3-1,5 \mathrm{~cm} \times 2-6 \mathrm{~mm}$, ovadas a elípticas, ápice agudo, margem fimbriada, apressas, persistentes. Folhas com pecíolo 1,3-8,5 cm compr., viloso a glabrescente; lâmina $2,7-10 \times 2-6 \mathrm{~cm}$, inteira, assimétrica, basifixa, membranácea, ovada, ápice agudo a arredondado, base cordada, margem crenada a irregularmente denteada, ciliada, glabrescente em ambas as faces; face adaxial verde, face abaxial verde-clara; venação actinódroma, 5-9 nervuras na base. Cimeiras (1)1,8-7,2 cm compr., (3)5-9 flores, 1 ou 2 nós; brácteas de primeira ordem 1,6-5 × 1-2,2 mm, ovadas a obovadas, persistentes. Flores estaminadas sem bractéolas; tépalas (2)4, alvas, as externas maiores, orbiculares a elípticas, face abaxial com esparsos tricomas glandulares microscópicos, as internas oblanceoladas, face abaxial glabra; estames 9-22, anteras rimosas, conectivos proeminentes. Flores pistiladas com 3 bractéolas ovadas, obovadas a espatuladas, persistentes; tépalas 
5, alvas, tamanhos semelhantes, elípticas a obovadas, face abaxial com esparsos tricomas glandulares microscópicos; ovário com placenta partida. Cápsulas $0,8-1,2 \times 1,5-2,4 \mathrm{~cm}$, com tricomas glandulares microscópicos a glabras; alas 3, desiguais, a maior $0,5-1,2 \mathrm{~cm}$ larg., ápice agudo a obtuso, as menores 3-5 $\mathrm{mm}$ larg., arredondadas. Sementes oblongas.

Ocorre nas Antilhas, Brasil, Colômbia e Peru (Jacques 2002). No Brasil, é encontrada na Bahia, Espírito Santo, Minas Gerais, Pará, Rio de Janeiro, Santa Catarina, São Paulo e Pernambuco (Jacques 2015). E6, E8, E9, F3, F8, G8, H8, I8, J8, K8: Floresta ombrófila densa submontana, floresta estacional semidecidual e cerrado, em áreas preservadas ou perturbadas. Habita locais úmidos e sombreados em mata ciliar, ou em solos arenosos entre rochas. Floresce e frutifica durante todo o ano.

Material selecionado - Coribe, Serra do Ramalho, ca. $5 \mathrm{~km}$ ao

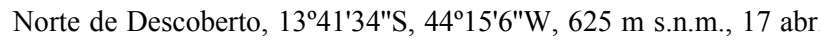
2002 (fl.), F. França et al. 3851 (HUEFS); Cruz das Almas, em viveiro de planta sob irrigação, 120 $40^{\prime} 12^{\prime \prime S}, 39^{\circ} 06^{\prime} 07^{\prime \prime} \mathrm{W}, 17$ nov. 1986 (fl.), G. Pinto 109 (BAH, HRB, MBM, UB); Guaratinga, lajedo na estrada de Buranhém, 16 $6^{\circ} 35^{\prime} 02^{\prime \prime} \mathrm{S}, 39^{\circ} 46^{\prime} 58^{\prime \prime} \mathrm{W}, 22$ abr. 2009 (fl., fr.), L. Kollmann et al. 11561 (MBML); Ibirapitanga, fazenda Boa Esperança, 1358'00"S, 39 27'00"W, 28 jun. 2012 (fr.), I.M. Souza 129 (HUEFS); Ilhéus, cultivada no Jardim Botânico, 1447'20"S, 3902'58"W, 15 jan. 1945 (fl.), H. Velloso 1111 a (RB); Itaeté, $12^{\circ} 56^{\prime} 41^{\prime \prime S}, 41^{\circ} 06^{\prime} 18^{\prime \prime} \mathrm{W}, 27$ jul. 2007 (fl.), O. Cano et al. 885 (IPA, UFP); Itapebi, São José, 1557'03"S, 39³2'02"W, 23 nov. 2006 (fl.), A.P. Fontana et al. 2543 (CEPEC, MBML, NY, RB); Ituberá, 134' $56^{\prime \prime S}, 39^{\circ} 08^{\prime} 57^{\prime \prime} \mathrm{W}, 19$ fev. 2011 (fl., fr.), $L$. Kollmann et al. 12204 (MBML); Lençóis, 12³3'47"S, 41²3'24"W, 6 jul. 1997 (fl.), M.L. Guedes et al. 4854 (ALCB, IPA); Mucuri, $18^{\circ} 05^{\prime} 11^{\prime \prime S}, 39^{\circ} 33^{\prime} 03^{\prime \prime W}, 15$ set. 1978 (fl.), S.A. Mori et al. 10566 (CEPEC, RB); Porto Seguro, $16^{\circ} 26^{\prime} \mathrm{S}, 39^{\circ} 05^{\prime} \mathrm{W}, 0-10$ m s.n.m., 21 mar. 1974 (fl.), R.M. Harley 17238 (CEPEC, RB); Salvador, 1258'16"S, 38³0'39"W, 11 jan. 1982 (fr.), G. Pinto 4 (CEPEC, HRB, RB); Santa Cruz Cabrália, 16 $16^{\circ} 41^{\prime \prime S}, 39^{\circ} 01^{\prime} 29^{\prime \prime} \mathrm{W}$, set. 1972 (fl.), A. Eupunino 284 (CEPEC, MBM); Santa Maria da Vitória, estrada para Água Quente, $13^{\circ} 15^{\prime} 44,8^{\prime \prime} \mathrm{S}, 44^{\circ} 16^{\prime} 05,0^{\prime \prime} \mathrm{W}, 16$ mar. 2010 (fl., fr.), K. Yoshida-Arns et al. 610 (UFP).

Material adicional - BRASIL. s.d. (fr.), F. Sellow 2192 (B [foto]).

Begonia hirtella é uma erva, caracterizada pelo indumento viloso, estípulas com margem fimbriada, lâminas foliares ovadas e membranáceas, flores pistiladas com 3 bractéolas, ala maior da cápsula com ápice agudo a obtuso e sementes oblongas. Assemelhase a $B$. delicata pelo indumento viloso, lâminas foliares membranáceas, cimeiras com poucas flores e 1 ou 2 nós. Begonia hirtella difere de $B$. delicata, pelo caule ereto (vs. prostrado), estípulas e brácteas de primeira ordem com margem fimbriada (vs. inteira), pecíolo glabro (vs. colar de tricomas no ápice) e pelas lâminas foliares ovadas (vs. arredondadas a transversalmente elípticas). Assemelha-se também a $B$. fischeri, podendo ser prontamente diferenciadas pela forma das sementes (obongas em B. hirtella e fusiformes em B. fischeri).
18. Begonia itaguassuensis Brade, Arch. Jard. Bot. Rio de Janeiro 8: 234; pl. 7. 1948.

Figuras $17 \mathrm{G}-\mathrm{M}$ e 18.

Ervas, $30-80 \mathrm{~cm}$ alt., hirsutas, pubescentes a glabriúsculas, tricomas simples, finos e tricomas de base espessa. Caule prostrado ou decumbente, glabrescente; entrenós 0,5-2,2 cm compr. Estípulas 1,6-4,2 × 0,8-2,5 cm, triangulares, ápice apiculado, margem inteira, carenadas, apressas, persistentes. Folhas com pecíolo 9-40 cm compr., hirsuto, pubescente ou glabriúsculo; lâmina $6-23 \times 8-35 \mathrm{~cm}$, inteira, assimétrica, basifixa, papirácea, arredondada a transversalmente elíptica, ápice acuminado, base cordada, margem denticulada, ciliada, híspida a glabriúscula em ambas as faces, mais densamente na face adaxial, face abaxial com indumento concentrado nas nervuras; face adaxial verde, face abaxial verdeclara a vinácea; venação actinódroma, 8-10 nervuras na base. Cimeiras 27-100 cm compr., 50-200 flores, 5 ou 6 nós; brácteas de primeira ordem $0,2-1,5 \mathrm{~cm} \times$ 0,9-5 mm, triangulares a lanceoladas, persistentes. Flores estaminadas sem bractéolas; tépalas 4, alvas, as externas maiores, ovadas a elípticas, face abaxial glabrescente a glabra, as internas estreitamente elípticas a oblongas, face abaxial glabra; estames 2462, anteras rimosas, conectivos proeminentes. Flores pistiladas com 2 bractéolas estreitamente triangulares, persistentes; tépalas 5, alvas, sendo três maiores, elípticas a oblanceoladas, face abaxial glabra; ovário com placenta inteira. Cápsulas $0,7-1 \times 0,9-2,8 \mathrm{~cm}$, sem tricomas microscópicos glandulares, glabras; alas 3, desiguais, a maior 0,5-1,5 cm larg., ápice arredondado, obtuso ou agudo, as menores 1,7-4 mm larg., arredondadas. Sementes oblongas.

Begonia itaguassuensis ocorre na Bahia, Espírito Santo e Pernambuco (Jacques 2015). F8, G7, G8, H7, H8: Floresta ombrófila densa montana e submontana. Ocorre sobre ou entre rochas, em solos arenosos ou no interior da mata. Floresce e frutifica durante todo o ano.

Material selecionado - Almadina, Serra do Corcovado, 14²42'21"S, 39³6'12"W, 11 abr. 2012 (bot., fl., fr.), B.S. Gregório 203 (CEPEC, HUEFS); Amargosa, Serra do Timbó. Barragem do Timbó, área de estudos do Projeto Timbó/Centro Sapucaia, 1304'57"S, 39³9'15"W, 897 m s.n.m., 29 jan. 2007 (fl., fr.), D. Cardoso et al. 1713 (CEPEC, HUEFS); Arataca, Serra do Peito de

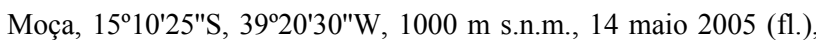
A.M. Amorim et al. 5005 (CEPEC, MBM, MBML, RB, SPF); Aurelino Leal, $14^{\circ} 20^{\prime} \mathrm{S}, 39^{\circ} 23^{\prime} \mathrm{W}, 3$ maio 1992 (fl.), W.W. Thomas et al. 9090 (CEPEC); Barro Preto, Serra da Pedra Lascada, 1446'13"S, 39³2'10"W, 10 abr. 2012 (bot., fl., fr.), B.S. Gregório 201 (CEPEC, HUEFS); Boa Nova, fazenda Riachão, 14²3'S, 40 $09^{\prime} \mathrm{W}, 780-850$ m s.n.m., 15 out. 2000 (fl., fr.), W.W. Thomas et

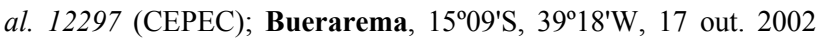
(fl., fr.), P. Fiaschi et al. 1150 (CEPEC, RB, SPF); Camacan, Reserva Particular do Patrimônio Natural Serra Bonita, Trilha da Bromélia, 15²3'30"S, 39³3'55"W, 830 m s.n.m., 12 fev. 2013 (bot., f1.), B.S. Gregório 215 (HUEFS); Itabuna, 1447'09"S, 39²16'48"W, 20 jul. 1967 (fl.), R.S. Pinheiro 129 (CEPEC); Itacaré, fazenda 


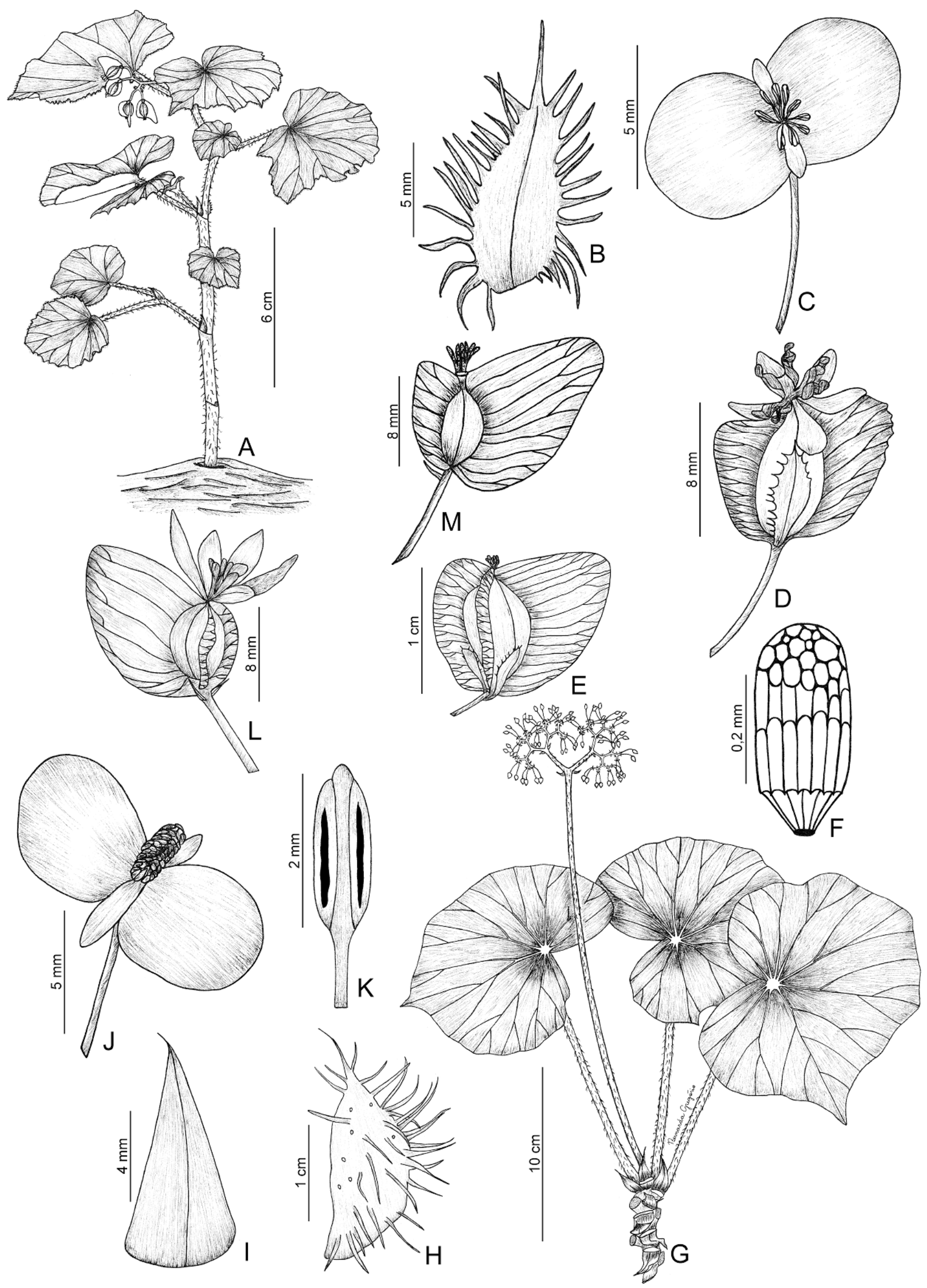

Figura 17. A-F. Begonia hirtella: A- hábito; B- estípula; C- flor estaminada; D- flor pistilada; E- cápsula; F- semente. G-M. B. itaguassuensis: G- ramo com botões; H- estípula pilosa; I- estípula glabra; J- flor estaminada; K- estame; L- flor pistilada; M- cápsula. (A-D- Eupunino 284; E, F- Santos 518; G, J, K- Lopes 383; H- Amorim 5382; I- Fiaschi 1533; L- Perdiz 47; M- Fiaschi 1837). 


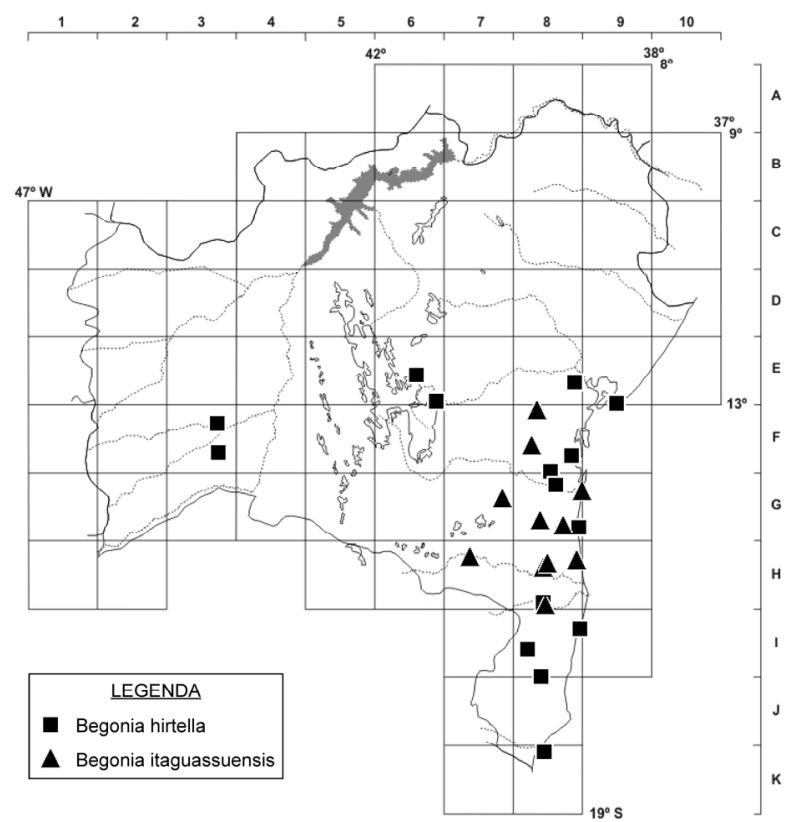

Figura 18. Mapa de distribuição de Begonia hirtella e B. itaguassuensis no estado da Bahia.

Bom Jesus, $14^{\circ} 16^{\prime} 39^{\prime \prime S}, 38^{\circ} 59^{\prime} 48^{\prime \prime} \mathrm{W}, 10$ ago. 1998 (fl., fr.), J.G. Jardim 1834 (CEPEC); Itambé, 15¹4'42"S, 40³7'28"W, 25 nov. 1970 (fl., fr.), L.E. Melo Filho 2916 (CEPEC, R, SPF); Itapebi,

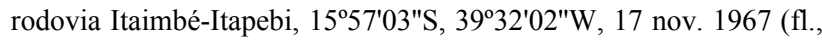
fr.), R.S. Pinheiro \& T.S. Santos 456 (CEPEC); Jussari, 15¹1'27"S, 39'29'42"W, fev. 1955 (fl.), G.C.P. Pinto 48 (CEPEC); Santa Luzia, Serra da Onça, 1520'S, 39³0'W, 21 nov. 1996 (fl., fr.), W.W. Thomas et al. 11375 (CEPEC, NY, RB, SPF); São José da Vitória, Pedra Brava, estrada São José-Una, $15^{\circ} 05^{\prime} 02^{\prime \prime S}$, 39²0'20"W, 1 maio 2001 (fl.), A.M. Amorim et al. 3650 (CEPEC); Una, $8,8 \mathrm{~km}$ a leste da BR-101, na estrada São José-Una, $15^{\circ} 08^{\prime} \mathrm{S}$, $39^{\circ} 15^{\prime} \mathrm{W}, 28$ out. 1993 (fl.), W.W. Thomas et al. 10181 (ALCB, CEPEC, MBM, MBML, NY, RB, SP, SPF); Wenceslau Guimarães, Estação Ecológica Estadual de Wenceslau Guimarães, Trilha da Petioba, 13³4'49"S, 3942'17"W, 24 maio 2013 (fl., fr.), B.S. Gregório 249 (HUEFS).

Material adicional - BRASIL. ESPÍRITO SANTO: Itaguassu, Jatiboca, 13 maio 1946 (fl., fr.), A.C. Brade et al. 18200 (holótipo de B. itaguassuensis: RB, isótipos: HB, SP, NY [foto], US [foto]). PERNAMBUCO: São Vicente Ferrer, Mata do Sirigi, trilha de acesso ao açude, 6 nov. 1999 (fl., fr.), M. Alves et al. 1670 (HUEFS, SP, UFP).

Begonia itaguassuensis é uma erva vistosa caracterizada pelo caule rizomatoso, prostrado ou decumbente, lâminas foliares arredondadas a transversalmente elípticas, com ápice acuminado, e brácteas de primeira ordem triangulares ou lanceoladas. Assemelha-se a $B$. pinheironis pelo hábito herbáceo, caule rizomatoso, prostrado ou decumbente, e pela forma das lâminas foliares. Begonia itaguassuensis difere daquela espécie pelo indumento hirsuto, pubescente ou glabriúsculo (vs. lanoso), escamas ausentes (vs. presentes) e bractéolas estreitamente triangulares das flores pistiladas (vs. linear-triangulares).
19. Begonia lossiae L.Kollmann, Rodriguésia 59(1): 156. 2008.

Figuras 19A, B e 20.

Ervas, ca. $20 \mathrm{~cm}$ alt., glabriúsculas a glabras, tricomas glandulares microscópicos. Caule ereto, glabriúsculo; entrenós 0,8-1 cm compr. Estípulas ca. 2 $\times 1 \mathrm{~cm}$, ovadas, ápice agudo, margem inteira, apressas, venosas, persistentes. Folhas com pecíolo $4-5 \mathrm{~cm}$ compr., glabriúsculo; lâmina ca. $8 \times 13 \mathrm{~cm}$, inteira, assimétrica, basifixa, crassa, transversalmente elíptica, ápice agudo, base cordada, margem serrilhada a irregularmente crenado-denticulada, ciliada, glabrescentes em ambas as faces; face adaxial verde, face abaxial verde-clara a vinácea; venação actinódroma, 9 nervuras na base. Cimeiras 12-20 cm compr., 10-28 flores, 2 ou 3 nós; brácteas de primeira ordem $0,5-0,7 \times 0,4-0,6 \mathrm{~mm}$, ovadas, persistentes. Flores estaminadas sem bractéolas; tépalas 4 , alvas a róseas, as externas maiores, lanceoladas a elípticas, face abaxial com esparsos tricomas glandulares microscópicos, as internas oblanceoladas, face abaxial glabra; estames 5-8, anteras rimosas, conectivos proeminentes. Flores pistiladas com 2 bractéolas ovadas, persistentes; tépalas 5, alvas, três levemente maiores, elípticas a oblongas, face abaxial com tricomas glandulares microscópicos; ovário com placenta inteira. Cápsulas $7-8,3 \times 4,5-5,5 \mathrm{~mm}$, com tricomas glandulares microscópicos; alas 3, iguais, inconspícuas. Sementes oblongas.

Begonia lossiae ocorre na Bahia e no Espírito Santo (Jacques 2015). I/J8: Floresta ombrófila densa montana. A espécie ocorre sobre rochas. Floresce de maio a novembro e frutifica em maio, junho e novembro (Kollmann 2012).

Material examinado - Itamaraju, fazenda Novo Pau-Brasil, Morro Pescoço, 16 599'43"S, 39³5'26"W, 11 maio 2013 (est.), B.S. Gregório 257 (HUEFS).

Material adicional - BRASIL. ESPÍRITO SANTO: Nova Venécia, Área de Proteção Ambiental da Pedra do Elefante, 400654 m s.n.m., 19 fev. 2008 (fl. fr.), L. Kollmann et al. 10682 (MBML); Santa Teresa, Alto Perdido, fazenda Montanhosa, propriedade dos Bridge, 700 m s.n.m., 14 abr. 2007 (fl., fr.), $L$. Kollmann et al. 9627 (holótipo de B. lossiae: MBML, isótipo: RB).

Begonia lossiae é uma erva rupícola, glabriúscula a glabra, com caule vermelho, estípulas venosas (característica única dentre as espécies que ocorrem na Bahia) e lâminas foliares brilhantes. A espécie, encontrada em associação com $B$. goldingiana, é registrada na Bahia apenas por registro fotográfico (Gregório 257), pois este único exemplar foi coletado, mantido em cultivo, mas morreu. Begonia lossiae assemelha-se a B. curtii pelo hábito subarbustivo e pelas estípulas venosas e persistentes. Ela é diferenciada pelas estípulas menores (ca. $2 \times 1 \mathrm{~cm}$ vs. 5,5-8 $\times 3,5-5 \mathrm{~cm}$ em B. curtii), ápice foliar agudo (vs. retuso), pecíolo glabro (vs. piloso), menor número de estames (5-8 vs. 14-22) e cápsulas com alas inconspícuas (vs. alas desenvolvidas). O material do Espírito Santo foi utilizado apenas para complementar a descrição das estruturas florais. 
20. Begonia mattos-silvae L.B.Sm. ex S.F.Sm. \& Wassh., Selbyana 20(1): 19; fig. 4. 1999.

Figuras $19 \mathrm{C}-\mathrm{G}$ e 20.

Ervas, $60 \mathrm{~cm}$ alt., glabriúsculas, tricomas simples de base espessa e esparsos tricomas glandulares microscópicos. Caule aparentemente prostrado ou decumbente, com esparsos tricomas glandulares microscópicos; entrenós 2-4 cm compr. Estípulas 1,7$2,5 \times 0,8-1,2 \mathrm{~cm}$, ovadas, ápice acuminado, margem inteira, apressas, aparentemente caducas. Folhas com pecíolo 20-40 cm compr., com esparsos tricomas glandulares microscópicos; lâmina 18-20 × 23-25 cm, inteira, assimétrica, basifixa, membranácea, arredondada a transversalmente elíptica, ápice acuminado, base cordada, margem crenada, esparsamente ciliada, glabrescente na face adaxial, glabra na face abaxial; verde em ambas as faces; venação actinódroma, 10 nervuras na base. Cimeiras 30-50 cm compr., 30-90 flores, 5 ou 6 nós; brácteas de primeira ordem ca. $1 \times 0,25 \mathrm{~mm}$, estreitamente triangulares, persistentes. Flores estaminadas sem bractéolas; tépalas 4, alvas, as externas maiores, orbiculares, face abaxial com esparsos tricomas glandulares microscópicos a glabras, as internas oblanceoladas, face abaxial glabra; estames 22-40, anteras rimosas, conectivos proeminentes. Flores pistiladas com 2 bractéolas estreitamente triangulares, caducas; tépalas 5, [cor não informada], sendo três maiores, elípticas a obovadas, face abaxial glabra; ovário com placenta inteira. Cápsulas $5-5,5 \mathrm{~mm} \times$ $1,2-1,6 \mathrm{~cm}$, com esparsos tricomas glandulares microscópicos [não vistas, obtidas pelo protólogo]; alas 3, desiguais, a maior $8-10 \mathrm{~mm}$ larg., ápice arredondado, as menores $2-3 \mathrm{~mm}$ larg., arredondadas. Sementes oblongas.

Endêmica do estado da Bahia (Jacques 2015), ocorre somente em Itamaraju. I/J8: Floresta ombrófila submontana. A espécie cresce sobre afloramentos rochosos, sendo também encontrada em áreas de plantação de cacau. Foi encontrada com flores e frutos em outubro.

Material examinado - Itamaraju, fazenda Pau-Brasil, $17^{\circ} 01^{\prime} \mathrm{S}, 39^{\circ} 33^{\prime} \mathrm{W}, 30$ out. 1979 (fl., fr.), L.A. Mattos Silva \& H.S. Brito 660 (holótipo de B. mattos-silvae: US [foto], isótipo: CEPEC).

Begonia mattos-silvae é caracterizada pelo caule prostrado ou decumbente, pecíolos longos, lâminas foliares arredondadas a transversalmente elípticas, com margem crenada e de textura membranácea. Assemelha-se a $B$. itaguassuensis, pelo aspecto geral da planta, a saber: hábito herbáceo; caule prostrado ou decumbente; folhas com pecíolo longo e lâmina assimétrica, arredondada a transversalmente elíptica, com ápice acuminado e base cordada. Begonia mattossilvae difere desta pelas lâminas foliares com margem crenada (vs. denticulada), brácteas de primeira ordem menores (ca. $1 \times 0,25 \mathrm{~mm}$ vs. $2-15 \times 0,9-5 \mathrm{~mm}$ ) e estreitamente triangulares (vs. triangulares a lanceoladas), e pelas tépalas estaminadas externas orbiculares (vs. ovadas a elípticas).
Begonia mattos-silvae é conhecida somente pelo material-tipo. Uma expedição de coleta foi realizada na área; outras espécies de Begonia foram encontradas, mas B. mattos-silvae não. A área encontra-se ocupada por plantações de cacau, café, entre outras culturas. A aplicação de herbicidas no entorno do cacaueiro e a capina são práticas comuns nas fazendas do sul da Bahia e, como foi visto em uma das expedições, essas práticas causam a morte de indivíduos de Begonia. Assim, é possível que as populações de $B$. mattossilvae estejam sendo negativamente afetadas por essas práticas.

21. Begonia neglecta A.DC., Ann. Sci. Nat., Bot., sér. 4, 11: 139. 1859.

$=$ Begonia membranacea A.DC., Ann. Sci. Nat., Bot., sér. 4, 11: 139. 1859. Syn. nov.

$=$ Begonia neglecta var caulescens A.DC., in Mart., Fl. Bras. 4(1): 372. 1861. Syn. nov.

$=$ Begonia cacauicola L.B.Sm. ex S.F.Sm. \& Wassh., Selbyana 20(1): 16; fig. 1. 1999. Syn. nov.

Figuras 21A-E e 22.

Ervas, $10-50 \mathrm{~cm}$ alt., glabriúsculas, tricomas simples, finos, de base espessa e esparsos tricomas glandulares microscópicos. Caule ereto a decumbente, glabriúsculo; entrenós 0,5-6,5 cm compr. Estípulas $0,5-2,5(-3,5) \mathrm{cm} \times 2-9(-12) \mathrm{mm}$, lanceoladas, ápice apiculado, margem inteira, apressas, persistentes. Folhas com pecíolo 3-23,5 cm compr., glabriúsculo, com colar de escamas no ápice; lâmina 8-26 × 4-18 $\mathrm{cm}$, inteira, assimétrica, basifixa, membranácea a papirácea, arredondada a transversalmente elíptica, ápice acuminado, base cordada, margem denticulada a crenada, ciliada, esparsamente pilosa a glabrescente em ambas as faces; face adaxial verde, face abaxial verdeclara com nuances vináceas; venação actinódroma, 610 nervuras na base. Cimeiras 10-28,5(-50) cm compr., 4-80 flores, 2-5 nós; brácteas de primeira ordem 4-8 × 2-4 mm, ovadas, caducas. Flores estaminadas sem bractéolas; tépalas (2)4, alvas, as externas maiores, orbiculares a ovadas, face abaxial com esparsos tricomas glandulares microscópicos a glabras, as internas obovadas a oblongas, face abaxial glabra; estames 9-58, anteras rimosas, conectivos proeminentes. Flores pistiladas com 2 bractéolas ovadas a elípticas, caducas; tépalas 5 , alvas a róseas, três maiores, ovadas a oblanceoladas, face abaxial com esparsos tricomas glandulares a glabras; ovário com placenta inteira. Cápsulas $1-1,6 \times 0,7-2,5 \mathrm{~cm}$, com esparsos tricomas glandulares microscópicos; alas 3, iguais a desiguais, a maior $0,2-1,2 \mathrm{~cm}$ larg., ápice arredondado a agudo, as menores 1,5-6 $\mathrm{mm}$ larg., redondas a agudas. Sementes oblongas.

Ocorre no estado da Bahia (Jacques 2015) e em Minas Gerais. G8, H7, H8: Floresta ombrófila densa montana e submontana. Habita solos humosos. Floresce e frutifica de janeiro a maio, e em agosto e setembro. 


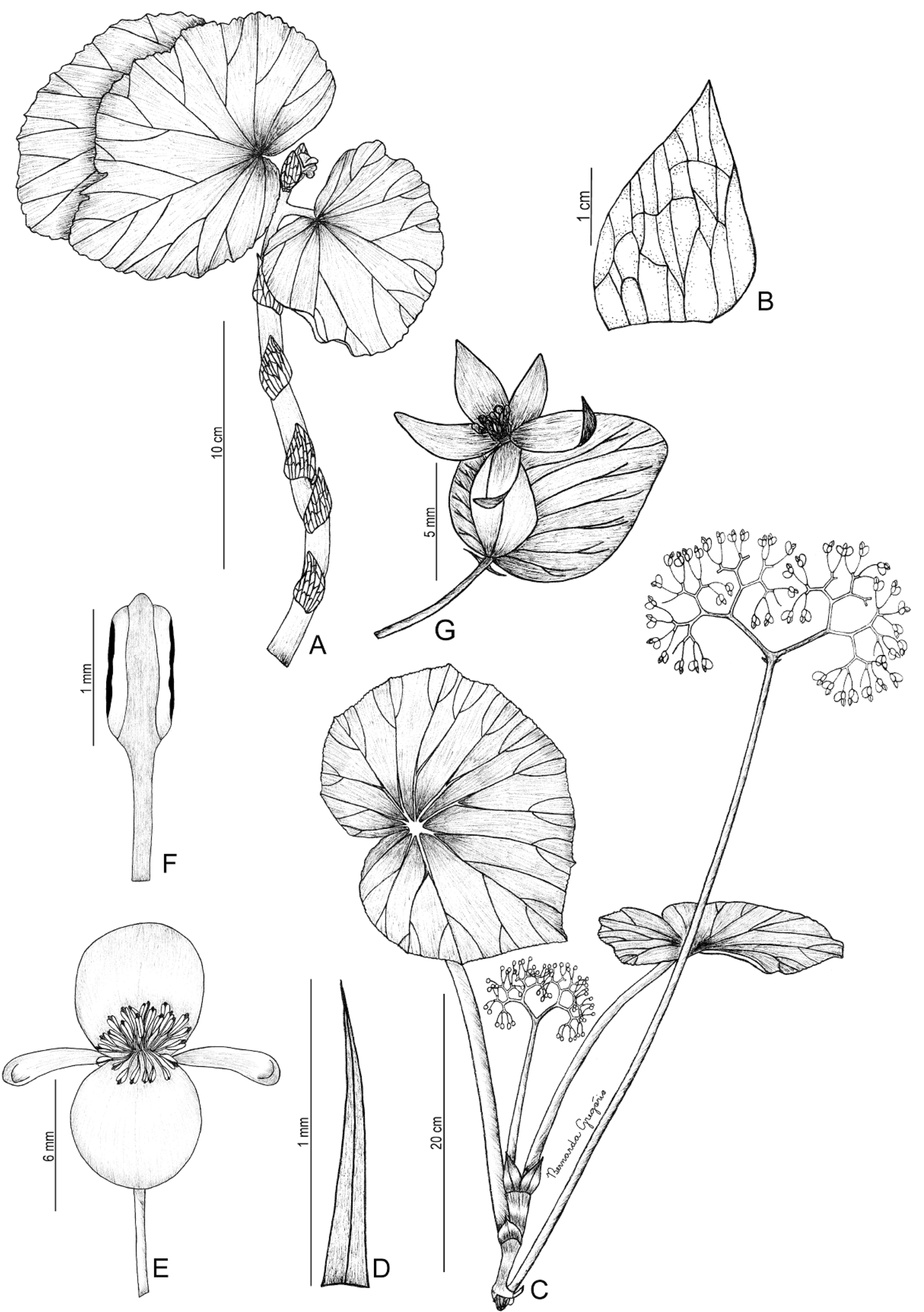

Figura 19. A, B. Begonia lossiae: A- ramo; B- estípula. C-G. B. mattos-silvae: C- ramo florido; D- bráctea de primeira ordem; E- flor estaminada; F- estame; G- flor pistilada. (A, B- Gregório 257; C-G- isótipo Mattos Silva 660). 


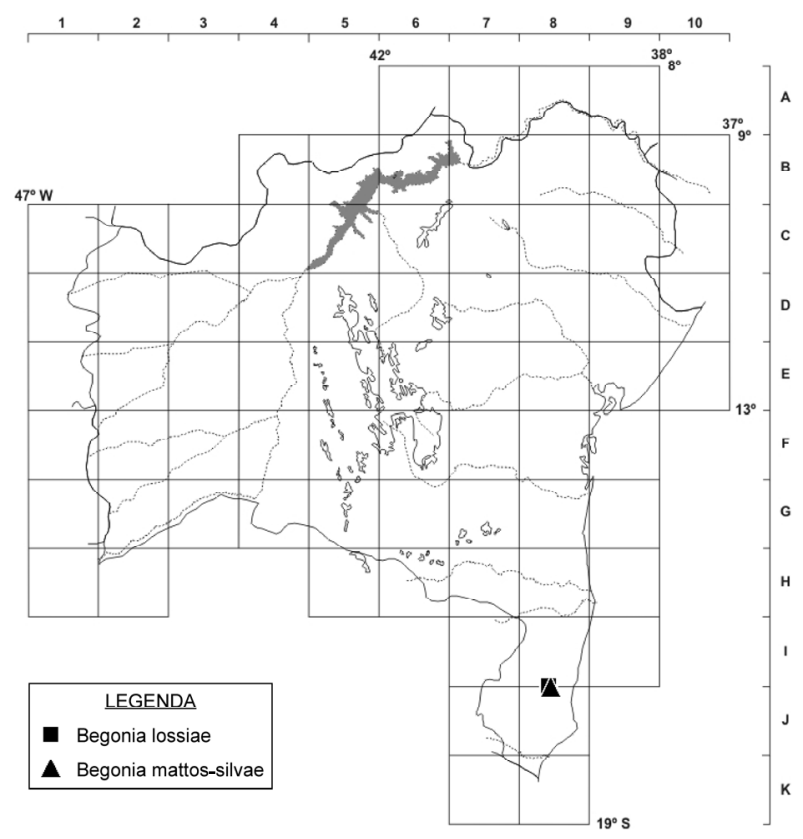

Figura 20. Mapa de distribuição de Begonia lossiae e B. mattossilvae no estado da Bahia.

Material selecionado - Almadina, Serra do Corcovado, 14²42'21"S, 39³6'12"W, 650-900 m s.n.m., 12 abr. 2012 (fl., fr.), B.S. Gregório 206 (HUEFS); Arataca, Serra das Lontras, 15²12'10"S, 39²4'29"W, 29 abr. 2006 (fl.), A.M. Amorim et al. 5953 (CEPEC, RB, SPF); Camacan, Reserva Particular do Patrimônio Natural Serra Bonita, trilha do Instituto, próximo à cachoeirinha, 15²3'30"S, 39³3'55"W, 835 m s.n.m., 13 fev. 2013 (bot., fl., fr.), B.S. Gregório 225 (HUEFS); Ilhéus, Castelo Novo, nas proximidades do rio Almada, 1447'20"S, 3902'58"W, 8 maio 2013 (fr.), B.S. Gregório 233 (HUEFS); ib., s.d. (fl.), C.F.P. Martius 955 (holótipo de B. neglecta: M [foto]); ib., s.d. (fl., fr.), L. Riedel s.n. (holótipo de B. membranacea: G-DC 7335 [foto]); Macarani, rodovia para Vila das Graças, 27,2 km a leste, ca. 4,4 km de Vila das Graças, 1546'19"S, 40²4'50"W, 560-600 m s.n.m., 17 ago. 2001 (fl., fr.), A.M. Carvalho et al. 7008 (ALCB, BAH, CEPEC, HRB, HUEFS); Una, fazenda São Bento, 15²17'36"S, 3904'31"W,18 maio 1965 (fl., fr.), R.P. Belém \& M. Magalhães 1002 (holótipo de B. cacauicola: US [foto], isótipos: CEPEC, UB).

Material adicional - BRASIL. MINAS GERAIS: Bandeiras, fazenda Boi Rajado, 5,9 km a leste de Macarani-Bandeiras, estrada para a fazenda, ca. $12 \mathrm{~km}$ ao norte de Bandeiras, 15\%48'23"S, 40³1'05"W, 830-850 m s.n.m., 30 jan. 2004 (fl., fr.), W.W. Thomas et al. 13662 (CEPEC); Santa Maria do Salto, fazenda Duas Barras, trilha partindo da sede até a divisa com a Bahia, 16²4'18,7"S, 4003'22,1"W, 776-755 m s.n.m., 9 mar. 2004 (fl.), J.A. Lombardi et al. 5993 (BHCB).

Begonia neglecta possui um colar de escamas vináceo no ápice do pecíolo, uma característica única dentre as espécies de Begoniaceae da Bahia. O tamanho do colar varia de 1,5 a $28 \mathrm{~mm}$ comprimento. Candolle (1861) descreveu a variedade caulescens para Ilhéus, com base no maior tamanho da planta, no caule de 7,5 cm de comprimento (vs. $5 \mathrm{~cm}$ compr.), no pedúnculo fértil com 12,5-15 cm de comprimento (vs. $7,5 \mathrm{~cm}$ compr.) e no tamanho das cápsulas, mas, neste caso, sem mencionar as medidas da variedade-tipo. Considerando-se a elevada variação morfológica de Begoniaceae devido ao hábitat, especialmente com relação ao tamanho das estruturas, conclui-se que as características utilizadas por Candolle são insuficientes para a manutenção de uma variedade. Diante disso, essa variedade não está sendo reconhecida neste estudo.

$\mathrm{Na}$ mesma obra em que descreveu Begonia neglecta, Candolle (1859) descreveu B. membranacea, também endêmica de Ilhéus, nas imediações de Castelo Novo. Candolle (1861) apontou a semelhança de suas folhas com as de $B$. neglecta, mas diferenciou as espécies pela cápsula maior em $B$. membranacea, assim como no caso de B. neglecta var. caulescens. No entanto, a medida da largura da ala da cápsula é equivalente para ambas $(14-16 \times 12-14 \mathrm{~mm}$ em $B$. membranacea vs $8-10 \times 12-14 \mathrm{~mm}$ em $B$. neglecta var. caulescens). A lâmina foliar de B. membranacea é descrita por Candolle como reniforme a arredondada, com 7-9 nervuras, já a de B. neglecta como obliquamente ovada, com 6-7 nervuras. Contudo, a ilustração de Candolle (1861, p.97) na Flora Brasiliensis exibe claramente $B$. neglecta var. neglecta com folhas reniformes.

Candolle (1861) cita que em B. neglecta possui duas sépalas e duas pétalas, que correspondem às tépalas, e em $B$. membranacea duas tépalas estão ausentes. Contudo, também foi observado, tanto em material herborizado quanto no campo, que é comum essa variação no número de tépalas de $B$. neglecta. Comparando o holótipo das duas espécies não existem diferenças significativas entre $B$. neglecta e $B$. membranacea. Pode-se, assim, concluir que se trata da mesma espécie, com uma ala dos frutos maior que as demais, a folha de forma reniforme com ápice acuminado, o pecíolo com colar de escamas no ápice e nervuras em número igual.

Mais recentemente, Begonia cacauicola foi descrita para o sul da Bahia com base nas seguintes características: "planta delicada, membranácea, glabra, com $40 \mathrm{~cm}$ de altura" (Smith \& Wasshasuen 1999, p.16). Ao examinar os isótipos (CEPEC, UB), verificou-se, além dos tricomas glandulares microscópicos originalmente descritos, a presença de esparsos tricomas simples de base espessa e suas cicatrizes nas lâminas foliares, bem como de um inconspícuo colar de escamas no ápice do pecíolo. A análise do aspecto geral da planta permitiu concluir que a espécie em questão é sinônimo de $B$. neglecta.

22. Begonia neocomensium A.DC., Ann. Sci. Nat., Bot., sér. 4, 11: 138. 1859.

$=$ Begonia euryphylla L.B.Sm. ex S.F.Sm. \& Wassh., Selbyana 20(1): 16; fig. 2. 1999. Syn. nov.

Figuras $21 \mathrm{~F}-\mathrm{K}$ e 22.

Ervas, $30-80 \mathrm{~cm}$ alt., estrigosas, tricomas simples, tricomas glandulares esparsos e escamas. Caule 


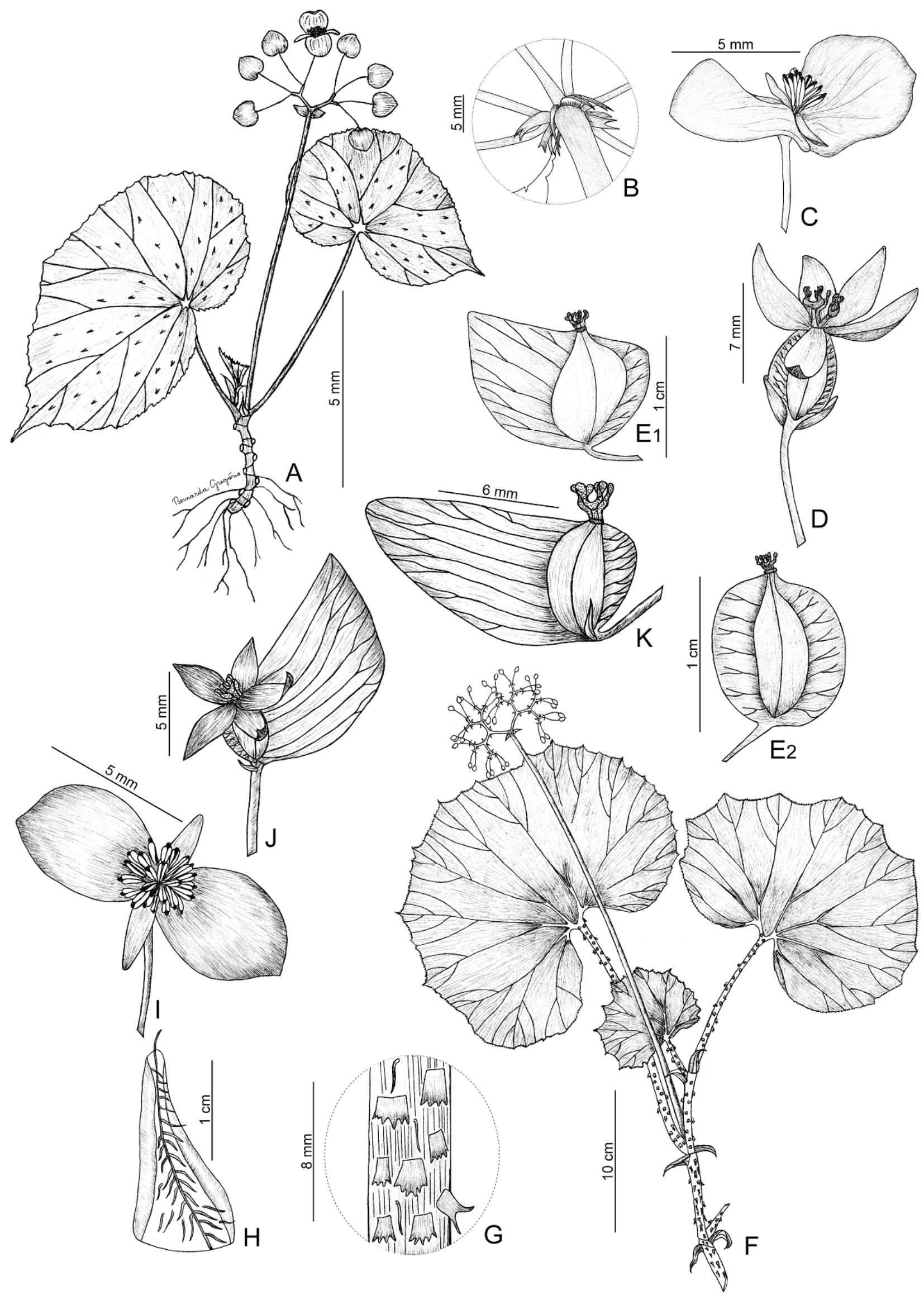

Figura 21. A-E. Begonia neglecta: A- hábito; B- detalhe do colar de escamas no ápice do pecíolo; C- flor estaminada; D- flor pistilada; E1, 2- cápsula. F-K. B. neocomensium: F- ramo florido; G- detalhe das escamas do caule; H- estípula; I- flor estaminada; J- flor pistilada; K- cápsula. (A, B, C, E1- Borges 416; D- Amorim 5698; E2- Jardim 4386; F, G, I, J- Hage 362; H- Gregório 237; K- Sobral 6756). 
prostrado ou decumbente, glabrescente; entrenós $0,5-5$ cm compr. Estípulas $2-3,7 \times 0,6-1,8 \mathrm{~cm}$, ovadas a lanceoladas, ápice apiculado, margem inteira, carenadas, apressas, persistentes. Folhas com pecíolo $7-42 \mathrm{~cm}$ compr., estrigoso; lâmina 8,8-25 × 12-34,5 $\mathrm{cm}$, inteira a levemente lobada, assimétrica, basifixa, papirácea, bulada, arredondada a transversalmente elíptica, 3-9-dentadas, ápices acuminados a obtusos, base cordada, margem serrilhada a crenulada, ciliada, estrigosa em ambas as faces, mais densamente na face adaxial, face abaxial com indumento concentrado nas nervuras; face adaxial verde, face abaxial verde-clara a vinácea; venação actinódroma, 5-8 nervuras na base. Cimeiras 17-70 cm compr., 16-90 flores, 4-7 nós; brácteas de primeira ordem $2-4(-18) \times 1-2(-7) \mathrm{mm}$, lanceoladas, persistentes. Flores estaminadas sem bractéolas; tépalas 4, alvas, tamanhos diferentes, as externas maiores, ovadas, orbiculares ou elípticas, face abaxial pilosa, com esparsos tricomas glandulares microscópicos, as internas elípticas, face abaxial glabra; estames 22-48, anteras rimosas, conectivos proeminentes. Flores pistiladas com 2 bractéolas lanceoladas, persistentes; tépalas 5 , alvas a róseas, três levemente maiores, elípticas a oblanceoladas, face abaxial com esparsos tricomas glandulares microscópicos; ovário com placenta inteira. Cápsulas 0,5-1 × 1,4-2,3 cm, glabrescentes, com esparsos tricomas glandulares microscópicos; alas 3, desiguais, a maior 0,9-1,7 cm larg., ápice arredondado, agudo a obtuso, as menores $0,7-4,5 \mathrm{~mm}$ larg., arredondadas. Sementes oblongas.

Begonia neocomensium era, até recentemente, conhecida apenas para o estado da Bahia (Smith et al. 1986), mas foi encontrada também em Minas Gerais (Feliciano 2009). G8, H7, H8: Floresta ombrófila densa submontana, floresta estacional semidecidual submontana e em cabruca. Cresce sobre ou entre rochas em solos úmidos, em locais ensolarados ou parcialmente ensolarados. Floresce em janeiro, agosto e outubro, e é encontrada com frutos em agosto e novembro.

Material selecionado - floresta da bacia do rio Grogongi, 100500 m s.n.m., 30 nov. 1915 (fl.), H.M. Curran 200 (US); Ilhéus, área do CEPEC, $\mathrm{Km} 22$ da rodovia Ilhéus-Itabuna, BR-415, 14\%47'20"S, 3902'58"W, 20 nov. 1979 (fl.), J.L. Hage 362 (CEPEC); ib., 1851 (fl., fr.), L. Dupasquier s.n. (holótipo de B. neocomensium: G-DC 457528 [foto]); Itagibá, Mata da Botinha, $14^{\circ} 10^{\prime} 53^{\prime \prime S}, 39^{\circ} 42^{\prime} 27^{\prime \prime} \mathrm{W}, 28$ set. 2008 (fl.), C.E. Ramos et al. 554 (ALCB); Itaju do Colônia, estrada para Santa Cruz da Vitória, 1508'33"S, 39²4'28"W, 15 jan. 1971 (fl.), T.S. Santos 1325 (CEPEC); Itapebi, Ventania, 1553'55"S, 39³3'54"W, 10 maio 2013 (est.), B.S. Gregório 237 (HUEFS); ib. 1553'554"S, 39³3'548"W, 16 ago. 1971 (fl., fr.), T.S. Santos 1842 (holótipo de B. euryphylla: US [foto], isótipo: CEPEC); Itarantim, Serra da Felicíssima, fazenda Bom Jardim, 15⒋ $48^{\prime} 18,7^{\prime \prime} \mathrm{S}, 40^{\circ} 30^{\prime} 59,8^{\prime \prime} \mathrm{W}$, 180-300 m s.n.m., 7 out. 2003 (fl.), A. Salino et al. 9134 (BHCB, MBM); Itororó, $15^{\circ} 07^{\prime} 01 " \mathrm{~S}, 40^{\circ} 04^{\prime} 13^{\prime \prime W}$, jan. 1991 (fl.), M. Sobral et al. $6756(\mathrm{SP})$

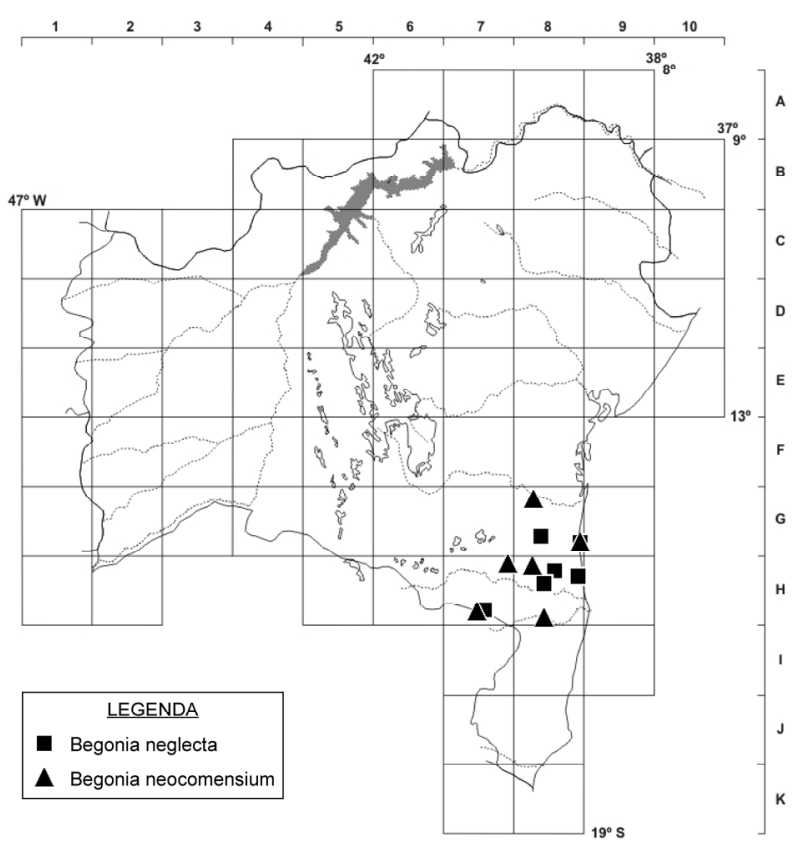

Figura 22. Mapa de distribuição de Begonia neglecta e B. neocomensium no estado da Bahia.

Begonia neocomensium caracteriza-se pelo revestimento escamoso, folhas com amplas lâminas arredondadas a transversalmente elípticas, buladas (característica exclusiva dentre as espécies que ocorrem no estado), 3-9 dentadas e pilosas. Além disso, as estípulas quando atingem a maturidade, apresentam margem revoluta. Begonia neocomensium assemelha-se a $B$. euryphylla pela morfologia geral da planta. Smith \& Wasshausen (1999) diferenciaram as duas espécies, considerando $B$. euryphylla mais robusta que $B$. neocomensium, por apresentar lâmina foliar mais aguda que arredondada e pelos entrenós curtos. Contudo, verificou-se que todas as características anteriormente mencionadas para $B$. euryphylla são encontradas em indivíduos de $B$. neocomensium. Os tipos de todos os nomes em questão foram analisados e, juntamente com a análise de outras coleções, permitiram concluir que $B$. euryphylla é sinônimo de B. neocomensium.

\section{Begonia obdeltata Gregório \& E.L.Jacques, Phytotaxa 167(2): 190. 2014.}

Figuras 23A-G e 24.

Ervas ou subarbustos, $0,3-1,5 \mathrm{~m}$ alt., pubescentes, tricomas estrelados e esparsos tricomas glandulares microscópicos. Caule ereto, glabrescente; entrenós $0,3-3 \mathrm{~cm}$ compr. Estípulas $0,7-2,3 \mathrm{~cm} \times 3-7 \mathrm{~mm}$, lanceoladas, ápice acuminado, margem inteira, carenadas, apressas, caducas. Folhas com pecíolo 3,3$12(-17) \mathrm{cm}$ compr., pubescente a glabrescente; lâmina $4,6-8(-11) \times 6,8-10(-15,5) \mathrm{cm}$, inteira, levemente assimétrica, basifixa, crassa, arredondada a transversalmente elíptica, ápice arredondado, base cordada, margem levemente ondulada, denteada, 
pubescente, com esparsos tricomas glandulares microscópicos em ambas as faces; face adaxial verde, face abaxial verde-pálida; venação actinódroma, 7 ou 8 nervuras na base. Cimeiras 24-50 cm compr., 70-180 flores, 5 ou 6 nós; brácteas de primeira ordem caducas [não vistas]. Flores estaminadas sem bractéolas; tépalas 2, alvas, largamente ovadas a orbiculares, face abaxial glabrescente; estames 14-22, anteras rimosas, conectivos não proeminentes. Flores pistiladas com 2 bractéolas oblongas, caducas; tépalas 5 , alvas a róseas, uma ligeiramente menor, obovadas a elípticas, face abaxial glabrescente; ovário com placenta inteira. Cápsulas $0,5-1,6 \times 0,6-1,3 \mathrm{~cm}$, glabrescentes, com tricomas glandulares microscópicos; alas 3, iguais, 1,5-4 mm larg., arredondadas. Sementes oblongas.

Ocorre nos estados da Bahia e Pernambuco (Gregório et al. 2014). E8, G8, H8: Floresta ombrófila densa montana e submontana. Cresce em áreas abertas, sobre rochas ou em tronco de árvores coberto por musgos. Encontrada com flores em abril e setembro, e com frutos em fevereiro, abril, setembro e outubro.

Material selecionado - Arataca, Parque Nacional da Serra das Lontras, 15 $12^{\circ} 17^{\prime \prime S}, 39^{\circ} 22^{\prime} 52^{\prime \prime} \mathrm{W}, 12$ set. 2011 (fl.), P. Leitman et al. 424 (CEPEC); Barro Preto, Serra da Pedra Lascada, 1446'13"S, 39³2'10"W, 10 abr. 2012 (est.), B.S. Gregório et al. 207 (HUEFS); Camacan, RPPN Serra Bonita, 9,6 km NNW de Camacan, na estrada para Jacareci e Jussari, em seguida $6 \mathrm{~km}$ até Serra Bonita, 1523'29"S, 39³3'55"W, 21 set. 2004 (fl, fr.), W.W. Thomas et al. 14222 (holótipo de B. obdeltata: CEPEC, isótipo: RB); ib., 1523'30"S, 39³3'55"W, 13 fev. 2013 (fr.), B.S. Gregório 230 (HUEFS, K, RB, SP, SPF, US); Santa Teresinha, Serra da Jiboia, ca. $4 \mathrm{~km}$ de Pedra Branca, 12 $51^{\prime} 10^{\prime \prime} \mathrm{S}, 39^{\circ} 28^{\prime} 32^{\prime \prime} \mathrm{W}, 27$ set. 2000 (fr.), L.P. Queiroz et al. 6364 (HUEFS, SPF).

Begonia obdeltata é uma planta preferencialmente rupícola, ocasionalmente epífita, caracterizada por cápsulas obdeltoides, com alas iguais. Assemelha-se a B. grisea, mas é facilmente distinta desta pelas estípulas lanceoladas (vs. triangulares), estiletes com 0,5-1,2 mm compr. (vs. 2-6 mm compr.) e cápsulas obdeltoides (vs. globulares) com alas iguais (vs. uma ala maior que as demais).

\section{Begonia paganuccii Gregório \& J.A.S.Costa, Phytokeys 44: 9. 2015.}

Figuras 23H-M e 24.

Subarbustos, ca. $3 \mathrm{~m}$ alt., pubescentes, tricomas dendríticos e glandulares microscópicos. Caule ereto, pubescente; entrenós 1-3,5 cm compr. Estípulas 2,5-3 $\times 0,7-1,5 \mathrm{~cm}$, lanceoladas, ápice apiculado, margem inteira, carenadas, apressas, caducas. Folhas com pecíolo 6,3-11,6 cm compr., pubescente; lâmina 13-18 $\times 19-28 \mathrm{~cm}$, lobada, 6 ou 7 lobos, recortes profundos, atingindo a metade da distância entre a margem e a nervura central, assimétrica, basifixa, subcrassa, transversalmente elíptica, lobos com ápice agudo, base cordada, margem serrilhada, pubescente em ambas as faces, mais densamente na face abaxial; face adaxial verde, face abaxial verde-cinérea; venação actinódroma, 6 ou 7 nervuras na base. Cimeiras 32-39 cm compr., 120-180 flores, 7 nós; brácteas de primeira ordem 4-6 6 1,5-2,5 mm, lanceoladas, caducas. Flores estaminadas sem bractéolas; tépalas 4, alvas, as externas maiores, ovadas a elípticas, côncavas, face abaxial glabrescente, as internas oblongas a oblanceoladas, côncavas, face abaxial glabra; estames 32-48, anteras rimosas, conectivos proeminentes. Flores pistiladas [não vistas], com 2 bractéolas caducas; ovário com placenta inteira [dados obtidos a partir das cápsulas]. Cápsulas 6-7,5 $\mathrm{mm} \times 1,1-1,5 \mathrm{~cm}$, glabrescentes, com tricomas glandulares microscópicos; alas 3, desiguais, a maior 6-7 mm larg., ápice obtuso a arredondado, as menores 0,6-1,6 $\mathrm{mm}$ larg., arredondadas. Sementes oblongas.

Endêmica da Bahia (Gregório et al. 2015). E7: Floresta estacional. Encontrada com flores e frutos em agosto.

Material examinado - Itaberaba, serra da fazenda Gameleira, entrando entre a fazenda Monte Verde e a fazenda Leão dos Brejos, $12^{\circ} 24^{\prime} 44^{\prime \prime S}, 40^{\circ} 32^{\prime} 12^{\prime \prime} \mathrm{W}, 19$ ago. 2005 (fl, fr), L.P. Queiroz et al. 10790 (holótipo de B. paganuccii: HUEFS, isótipos: CEPEC, HUEFS, K, RB)

Begonia paganuccii assemelha-se a $B$. reniformis Dryand., da qual se diferencia pela presença de tricomas dendríticos (vs. tricomas simples), estípulas lanceoladas (vs. triangulares), e pelas lâminas foliares com recortes profundos, atingindo a metade da distância entre a margem e a nervura central (vs. recortes superficiais, não atingindo a metade da distância entre a margem e a nervura central).

25. Begonia pernambucensis Brade, Arch. Jard. Bot. Rio de Janeiro 13: 82; fig. 7.1954.

$=$ Begonia petasitifolia Brade, Bradea 1(6): 37; fig. 1. 1971.

Figuras $25 \mathrm{~A}-\mathrm{F}$ e 26

Ervas, 0,3-1,5 $\mathrm{m}$ alt., pubescentes a tomentosas, tricomas estrelados. Caule prostrado ou decumbente, glabrescente; entrenós 1-3 mm compr. Estípulas 1,5-3 $\times 0,8-1,8 \mathrm{~cm}$, triangulares, ápice apiculado, margem inteira, carenadas, apressas, persistentes. Folhas com pecíolo 3-59 cm compr., tomentoso; lâmina 4,5-18,7 × 6-22,3 cm, inteira, levemente assimétrica, basifixa, coriácea a crassa, arredondada a transversalmente elíptica, ápice arredondado a obtuso, base cordada, margem inteira a levemente ondulada, tomentosa em ambas as faces, mais densamente na face abaxial, glabrescente na face adaxial; face adaxial verde, face abaxial verde-pálida; venação actinódroma, 6-9 nervuras na base. Cimeiras 17-125 cm compr., 20150 flores, 4-7 nós; brácteas de primeira ordem $0,8-$ $1,3 \mathrm{~cm} \times 3-5 \mathrm{~mm}$, oblongas a elípticas, caducas. Flores estaminadas sem bractéolas; tépalas 4, alvas, as externas maiores, largamente ovadas a orbiculares, face abaxial glabrescente; as internas oblanceoladas, face abaxial glabra; estames 6-24, anteras rimosas, conectivos proeminentes. Flores pistiladas com 2 bractéolas estreitamente elípticas a oblongas, caducas; tépalas $5(-7)$, alvas a róseas, três ligeiramente maiores, 


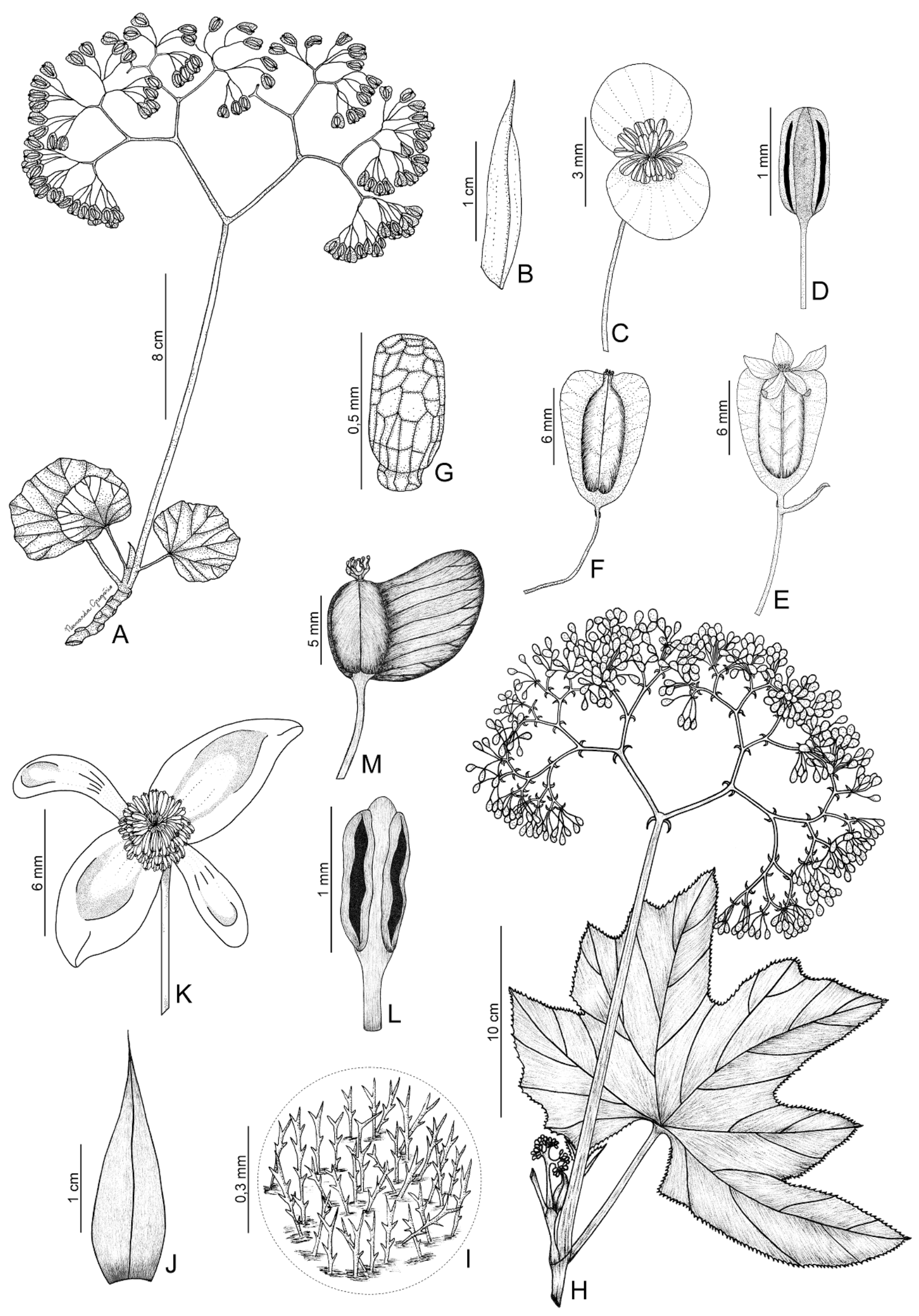

Figura 23. A-G. Begonia obdeltata: A- ramo com frutos; B- visão dorso-lateral da estípula; C- flor estaminada; D- estame; E- flor pistilada; F- cápsula; G- semente. H-M. B. paganuccii: H- ramo florido; I- detalhe do indumento da lâmina foliar; J- estípula; K- flor estaminada; L- estame; M- cápsula. (A, B, F, G- Gregório 230; C-E- Thomas 14222; H-M- holótipo Queiroz 10790). 


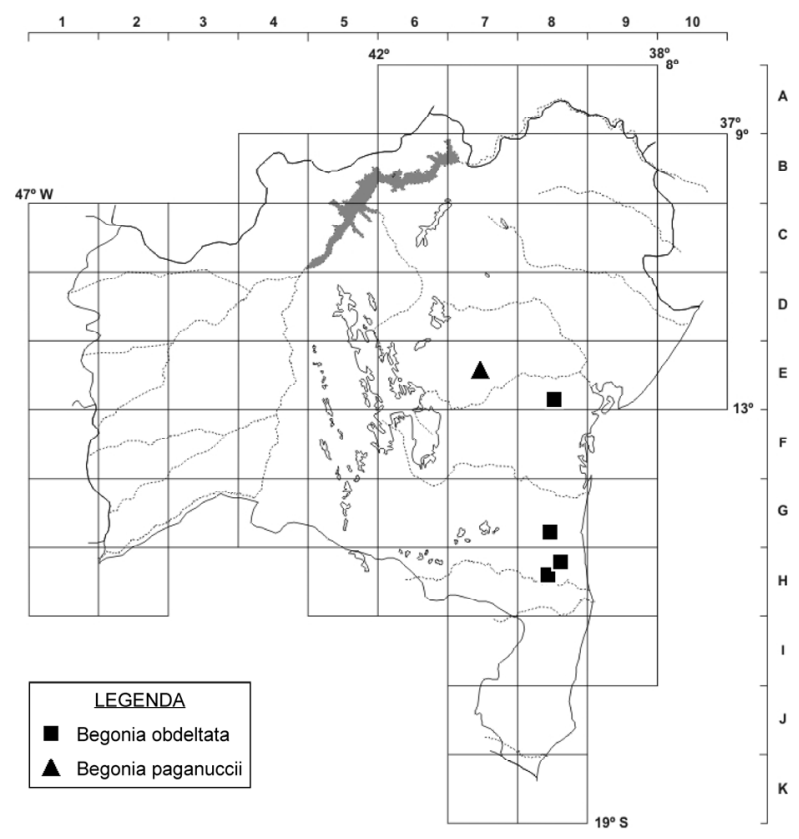

Figura 24. Mapa de distribuição de Begonia obdeltata e B. paganuccii no estado da Bahia.

elípticas a ovadas, face abaxial glabra; ovário com placenta inteira, raramente com a placenta de um dos lóculos lobada. Cápsulas $0,7-1,7 \times 0,9-1,8 \mathrm{~mm}$, pilosas a glabrescentes, sem tricomas glandulares microscópicos; alas 3, desiguais, a maior 3-6 mm larg., ápice arredondado a agudo, as menores 1-4 mm larg., arredondadas. Sementes oblongas.

Descrita para Pernambuco (Brade 1954), tem sua distribuição ampliada com a inclusão de $B$. petasitifolia, descrita para a Bahia (Brade 1971), em sua sinonímia; além disso, também foi registrada em Alagoas. C6, C7, D6, D7, E7: Mata de galeria, mata ciliar, mata seca, campo sujo, capão de mata, floresta estacional, campo rupestre e caatinga. Habita afloramentos rochosos com solos hidromórficos ou litólicos, fendas de rochas ou solos argilosos à sombra, no interior da vegetação. Floresce de fevereiro a novembro e frutifica de julho a novembro e em fevereiro

Material selecionado - Itaberaba, fazenda Gameleira, entrando entre a fazenda Monte Verde e a fazenda Leão dos Brejos, $12^{\circ} 25^{\prime} 2 " \mathrm{~S}, 40^{\circ} 32^{\prime} 14^{\prime \prime} \mathrm{W}, 649 \mathrm{~m}$ s.n.m., 19 ago. 2005 (fl.), L.P. Queiroz et al. 10751 (HUEFS); Jacobina, entrada a $8 \mathrm{~km}$ na rodovia Jacobina-Capim Grosso, $11^{\circ} 10^{\prime} 50^{\prime \prime} \mathrm{S}, 40^{\circ} 31^{\prime} 06^{\prime \prime} \mathrm{W}, 27$ out. 1995 (fl., fr.), J.G. Jardim et al. 725 (ALCB, CEPEC, HRB); Morro do Chapéu, $1000 \mathrm{~m}$ s.n.m., 10 set. 1956 (fl., fr.),

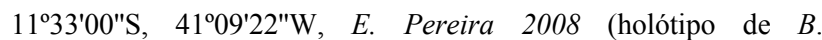
petasitifolia: RB, isótipo: $\mathrm{HB}$ ); área da Cachoeira do Ferro Doido, $11^{\circ} 36$ 'S, 41 ${ }^{\circ} 03^{\prime} \mathrm{W}, 28$ jan. 2013 (bot., fl., fr.), B.S. Gregório 210 (CEPEC); Pindobaçu, Serra da Fumaça, 10³8'54"S, 40²2'34"W, 26 out. 2008 (bot., fl.), L.A. Sousa 164 (HUEFS) Ruy Barbosa, Serra do Orobó, $12^{\circ} 18^{\prime} 52^{\prime \prime S}, 40^{\circ} 28^{\prime} 32^{\prime \prime W}, 700$ m s.n.m., 28 jul. 2004 (fr.), L.P. Queiroz et al. 9334 (HUEFS); Senhor do Bonfim, alto da Serra de Santana, 10²1'46"S, 40'12'8"W, 28 jul. 2005 (fl.), T.S. Nunes et al. 1187 (HUEFS); Sento Sé, Serra da Imbaúba, $10^{\circ} 19^{\prime} 54,60^{\prime \prime S}, 41^{\circ} 24^{\prime} 51,20^{\prime \prime} \mathrm{W}, 1163$ m s.n.m., 15 maio 2010 (fl.), A.P. Fontana et al. 6712 (MBML).

Material adicional - BRASIL. ALAGOAS: Quebrangulo, REBIO Pedra Talhada, em cima da Pedra Talhada, 09 $15^{\prime} 17^{\prime \prime S}$, 36 25'36"W, 25 nov. 2011 (fl.), D. Araújo et al. 1820 (UFP). PERNAMBUCO: dez. 1948 (fl.), E. Kuhlmann 2 (holótipo de $B$. pernambucensis: RB); Tacaratu, Fonte Grande, 09 $04^{\prime} 58^{\prime \prime} \mathrm{S}$, $38^{\circ} 08^{\prime} 18^{\prime \prime} \mathrm{W}, 600$ m s.n.m., 9 set. 2009 (fl., fr.), A.P. Fontana et al. 2010 (MBML).

Begonia pernambucensis caracteriza-se pelo caule rizomatoso, prostrado ou decumbente, com entrenós muito curtos e revestidos por estípulas persistentes, pelas lâminas foliares transversalmente elípticas a arredondadas, pubescentes a tomentosas, com tricomas estrelados brancos ou ferrugíneos, pelas cimeiras que ultrapassam o tamanho das folhas e pelas flores estaminadas com quatro tépalas. Begonia pernambucensis assemelha-se a $B$. grisea pelo tipo de indumento, estípulas triangulares, carenadas e com ápice apiculado, e pela forma das folhas, cápsulas e sementes. A espécie é prontamente diferenciada pelas características mencionadas nos comentários de $B$. grisea.

Begonia petasitifolia, descrita para Morro do Chapéu, na Bahia, foi incluída por Brade (1971) na seção Pritzelia, mesma seção de B. pernambucensis. As duas espécies são idênticas, diferenciadas apenas pela presença esporádica de placenta lobada em um dos lóculos do ovário em B. pernambucensis. No entanto, essa variação da placenta não é suficiente para o reconhecimento de $B$. petasitifolia como espécie distinta de $B$. pernambucensis. Sendo assim, propõe-se aqui a sinonimização de $B$. petasitifolia sob $B$. pernambucensis.

26. Begonia pinheironis L.B.Sm. ex S.F.Sm. \& Wassh., Selbyana 20(1): 21; figs 21 e 22. 1999.

Figuras 25G-L e 26.

Ervas, 18-60 cm alt., lanosas, escamas finas, esparsos tricomas simples e estrelados. Caule prostrado ou decumbente, lanoso; entrenós $0,5-3,8 \mathrm{~cm}$ compr. Estípulas $2-3,5 \times 0,8-1,3 \mathrm{~cm}$, ovadas, ápice apiculado, margem inteira, carenadas, apressas, persistentes. Folhas com pecíolo $12-30 \mathrm{~cm}$ compr., glabriúsculo; lâmina $8,5-17,8 \times 12-22,5 \mathrm{~cm}$, inteira, assimétrica, basifixa, subcrassa, arredondada a transversalmente elíptica, ápice acuminado, base cordada a subcordada, margem inteira a levemente denticulada, glabrescente na face adaxial, lanosa na face abaxial; face adaxial verde, face abaxial ferrugínea; venação actinódroma, 9-11 nervuras na base. Cimeiras 24-85 cm compr., 40-90 flores, 5 ou 6 nós; brácteas de primeira ordem, $0,7-1,3(-1,7) \mathrm{cm} \times$ 0,6-1,5(-5) $\mathrm{mm}$, linear-triangulares a lanceoladas, persistentes. Flores estaminadas sem bractéolas; tépalas 4, alvas, as externas maiores, orbiculares a elípticas, face abaxial glabrescente, as internas elípticas, face abaxial glabra; estames 26-44, anteras rimosas, conectivos proeminentes. Flores pistiladas 


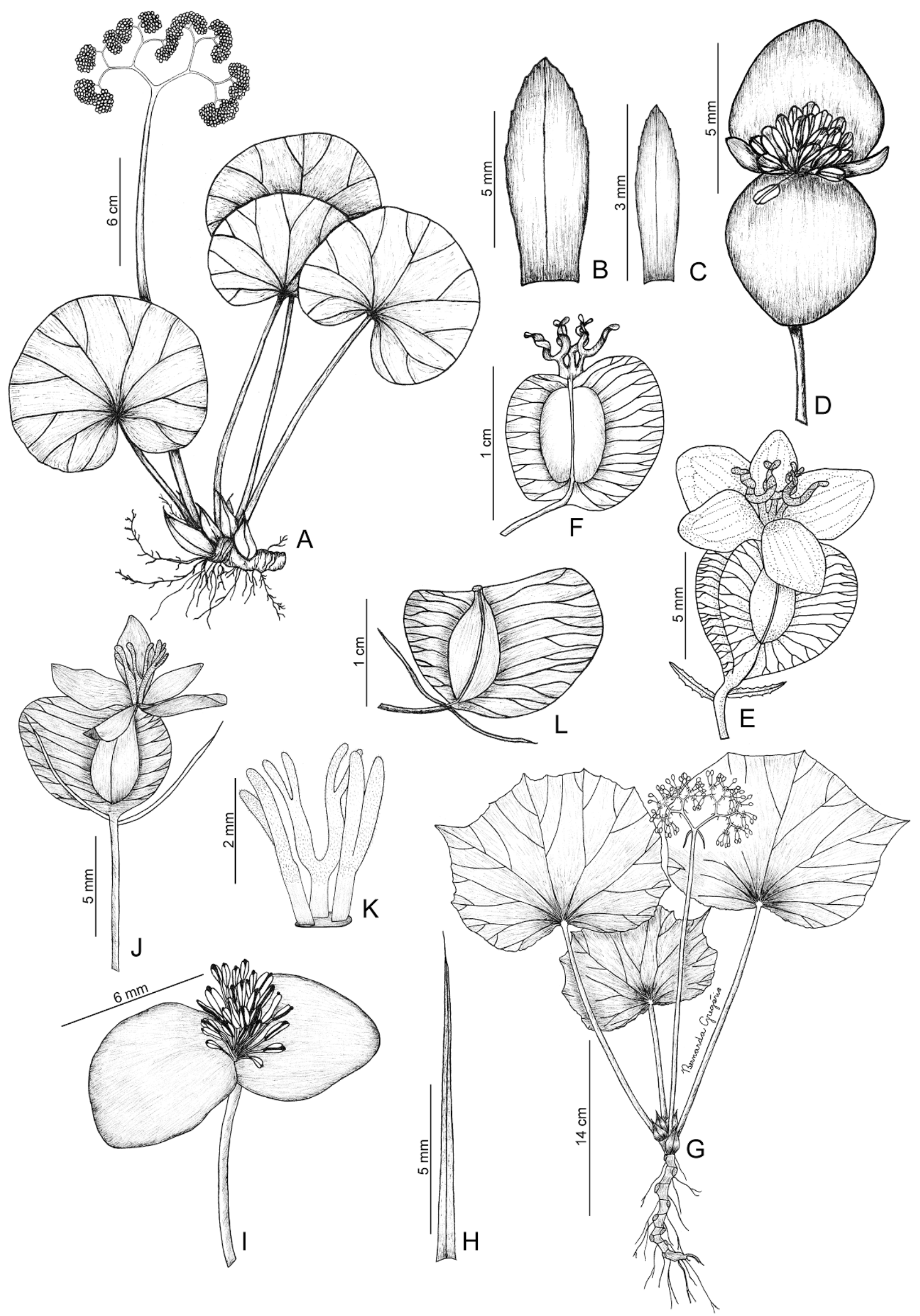

Figura 25. A-F. Begonia pernambucensis: A- hábito; B- bráctea de primeira ordem; C- bractéola da flor pistilada; D- flor estaminada; E- flor pistilada; F- cápsula. G-L. B. pinheironis: G- hábito; H- bráctea de primeira ordem; I- flor estaminada; J- flor pistilada; K-estiletes; L- cápsula. (A, B- Silva 203; C, E- Gregório 210; D- Cardoso 659; F- Furlan 285; G-I- Oliveira 738; J, K- Oliveira 740; L- Jardim 1497). 


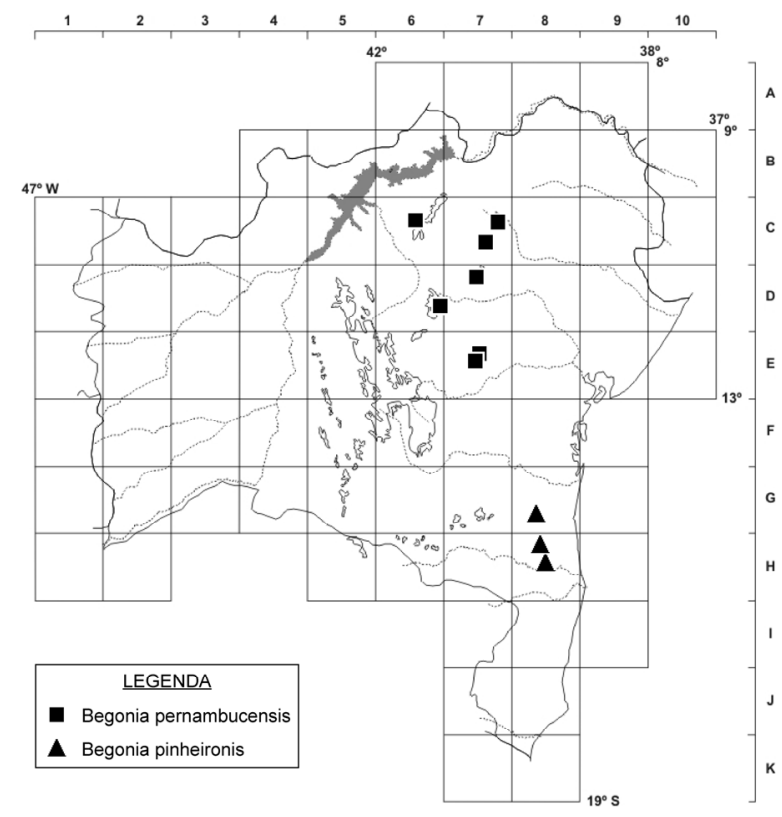

Figura 26. Mapa de distribuição de Begonia pernambucensis e B. pinheironis no estado da Bahia.

com 2 bractéolas linear-triangulares; tépalas 5, alvas, elípticas a obovadas, face abaxial glabrescente; ovário com placenta inteira. Cápsulas $1-1,7 \times 1,3-2,4 \mathrm{~cm}$, glabrescentes a glabras, sem tricomas glandulares microscópicos; alas 3, desiguais, a maior $0,6-1,3 \mathrm{~cm}$ larg., ápice arredondado a obtuso, as menores 4-6,5 mm larg., arredondadas. Sementes oblongas.

Endêmica do estado da Bahia (Jacques 2015). G8, H8: Floresta ombrófila densa montana e submontana. Ocorre sobre rochas e árvores ou em solos arenosos, ricos em húmus, no interior da mata. Foi encontrada com flores em abril, de julho a setembro e em dezembro; coletada com frutos em fevereiro, agosto, setembro e dezembro.

Material selecionado - Almadina, fazenda Beija-flor, Serra da Pancadinha, entrada a $1 \mathrm{~km}$ da rodovia Almadina-Floresta Azul,

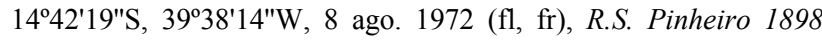
(holótipo de B. pinheironis: US [foto]); Camacan, ramal que liga Biscó ao povoado de São João do Panelinha, Km 4, 15²5'09"S, 39²9'45"W, 14 jul. 1978 (fl.), T.S. Santos \& L.A. Mattos Silva 3302 (CEPEC); Jussari, Reserva Particular do Patrimônio Natural Serra do Teimoso, $15^{\circ} 10^{\prime} \mathrm{S}, 39^{\circ} 35^{\prime} \mathrm{W}, 300-450$ m s.n.m., 20 dez. 1998 (fl., fr.), A.M. Carvalho et al. 6704 (CEPEC).

Begonia pinheironis é uma erva terrestre, ou ocasionalmente epífita, lanosa, caracterizada por lâminas foliares arredondadas a transversalmente elípticas com face abaxial ferrugínea, brácteas de primeira ordem e bractéolas das flores pistiladas lineartriangulares, estiletes não espiralados, não unidos na base e, pelo menos um deles, duas vezes bífido. Assemelha-se a $B$. itaguassuensis pelo hábito herbáceo, caule prostrado ou decumbente e forma das lâminas foliares, mas é facilmente diferenciada desta, pelo indumento lanoso (vs. hirsuto, pubescente a glabriúsculo), margem das lâminas foliares inteira a levemente denticulada (vs. denticulada) e pelas bractéolas das flores pistiladas linear-triangulares (vs. estreitamente triangulares).

27. Begonia polygonifolia A.DC. in Martius, F1. Bras. 4(1): 362. 1861.

$=$ Begonia polygonifolia var differens L.B.Sm. ex S.F.Sm. \& Wassh., Selbyana 20(1): 24; fig.7. 1999. Syn. nov.

Figuras 27A-E e 28.

Trepadeiras, 3-7 m compr., glabriúsculas, esparsos tricomas simples e glandulares microscópicos. Caule escandente, glabriúsculo; entrenós 1,5-10 cm compr. Estípulas $1-2,2 \times 0,7-1,3 \mathrm{~cm}$, ovadas, ápice apiculado, margem inteira, carenadas, apressas, persistentes. Folhas com pecíolo 0,2-1,7 cm compr., glabriúsculo; lâmina $5,3-12 \times 2-4,5 \mathrm{~cm}$, inteira, assimétrica, basifixa, papirácea, elíptica a oblanceolada, ápice acuminado, base oblíqua, margem inteira a esparsamente denteada, glabra na face adaxial, com esparsos tricomas glandulares microscópicos na face abaxial; face adaxial verde, face abaxial verdeclara a vinácea; venação craspedódroma. Cimeiras 625 cm compr., 40-100 flores, 4-6 nós; brácteas de primeira ordem $1-4 \times 2-4 \mathrm{~mm}$, triangulares, caducas. Flores estaminadas sem bractéolas; tépalas 4, alvas, as externas maiores, orbiculares a obovadas, côncavas, face abaxial com esparsos tricomas glandulares microscópicos, as internas oblanceoladas, côncavas, face abaxial glabra; estames 20-38, anteras rimosas, conectivos proeminentes. Flores pistiladas com 2 bractéolas estreitamente triangulares, caducas; tépalas 5 , alvas a róseas, três maiores, obovadas a elípticas, côncavas, face abaxial com esparsos tricomas glandulares microscópicos; ovário com placenta inteira. Cápsulas $6-8 \mathrm{~mm} \times 1,5-1,9 \mathrm{~cm}$, com tricomas glandulares microscópicos; alas 3, desiguais, a maior 1-2 cm larg., ápice agudo a obtuso, as menores 2-5 mm larg., arredondadas a agudas. Sementes lineares.

Ocorre na Bahia e Espírito Santo (Jacques 2015). G8, I8: Floresta ombrófila densa montana e submontana. A espécie cresce sobre árvores ou rochas, plantações de cacau e matas pouco perturbadas. Foi encontrada com flores de setembro a dezembro e com frutos em novembro e dezembro.

Material selecionado - s.d. (bot., fl.), F. Sellow s.n. (B 10 02430754 [foto]); Almadina, fazenda Beija-flor, ramal com entrada no Km 3 da rodovia Almadina-Floresta Azul, no final do ramal, 14²42'19"S, 39³8'14"W, 9 nov. 1978 (fl., fr.), T.S. Santos et al. 3383 (holótipo de B. polygonifolia var. differens: US [foto], isótipo: CEPEC); Eunápolis, rodovia BR-5, $10 \mathrm{~km}$ ao sul de Eunápolis, $16^{\circ} 22^{\prime} 39^{\prime \prime S}, 39^{\circ} 34^{\prime} 49^{\prime \prime} \mathrm{W}, 22$ set. 1966 (fl.), R.P. Belém \& R.S. Pinheiro 2629 (UB); Ilhéus, área do CEPEC, quadra I, 14²5'21"S, 39¹4'2"W, 50 m s.n.m., 8 set. 1981 (fl.), J.L. Hage 1311 (CEPEC); Itabuna, Km 9 da estrada Jussari-Palmeira, fazenda Santo Antônio, $14^{\circ} 47^{\prime} 08^{\prime \prime S}, 39^{\circ} 16^{\prime} 49^{\prime \prime W}, 300 \mathrm{~m}$ s.n.m., 28 out. 1983 (fl.), $R$. Callejas et al. 1568 (MBM, NY).

Begonia polygonifolia assemelha-se a $B$. fruticosa pelo hábito trepador, indumento glabriúsculo, pecíolo curto e flores estaminadas com quatro tépalas 
côncavas. Begonia polygonifolia difere desta, pelas estípulas ovadas (vs. lanceoladas), lâminas foliares com margem inteira a esparsamente denteada (vs. serreada) e cápsulas com alas desiguais, sendo uma maior (vs. alas iguais).

Begonia polygonifolia var. differens foi descrita como endêmica da Bahia, sendo reconhecida pelos pecíolos maiores $(1,5 \mathrm{~cm}$ compr. ou mais vs. subséssil, $0,2 \mathrm{~cm}$ compr. em $B$. polygonifolia var. polygonifolia) e pelas lâminas foliares elípticas (vs. oblongas). Durante este estudo, constatou-se que as características mencionadas anteriormente não são consistentes para a delimitação de variedades, pois um mesmo indivíduo pode possuir tanto folhas sésseis como folhas com pecíolos longos. A forma das lâminas foliares também é variável e de pouco valor no reconhecimento de táxons infraespecíficos. Dessa forma, B. polygonifolia var. differens não é reconhecida como distinta da variedade típica.

28. Begonia radicans Vell., Fl. Flum. Icon. 10: pl. 39. 1831 [como ' 1827 '].

Figuras 27F-J e 28.

Trepadeiras, 3-5 m compr., glabriúsculas, tricomas simples e glandulares microscópicos. Caule escandente, glabriúsculo a glabro; entrenós 1,5-6,5 cm compr. Estípulas $0,8-1,5 \mathrm{~cm} \times 5-7 \mathrm{~mm}$, triangulares, ápice acuminado, margem inteira, apressas, caducas. Folhas com pecíolo 1,2-5 cm compr., glabriúsculo; lâmina 5-18,2 × 2-8,6 cm, inteira, levemente assimétrica, basifixa, papirácea, ovada ou elíptica, ápice acuminado, base levemente oblíqua, margem plana a levemente ondulada, glabra em ambas as faces; face adaxial verde, face abaxial verde-clara a vinácea; venação actinódroma, 5 ou 6 nervuras na base. Cimeiras 9,5-15 cm compr., 20-40 flores, 2-5 nós; brácteas de primeira ordem 1,5-2,5 × 1-1,3 cm, elípticas, caducas. Flores estaminadas sem bractéolas; tépalas 4, vermelhas, as externas maiores, ovadas, face abaxial glabra, as internas oblanceoladas, face abaxial glabra; estames 12-26, anteras poricidas, conectivos não proeminentes. Flores pistiladas sem bractéolas; tépalas 5, vermelhas, tamanhos semelhantes, oblanceoladas, elípticas a ovadas, face abaxial glabra; ovário com placenta partida. Cápsulas 1,5-1,8 × 2,4 $3,1 \mathrm{~cm}$, com esparsos tricomas glandulares microscópicos; alas 3, desiguais, a maior 1,3-1,5 cm larg., ápice arredondado a obtuso, as menores 2,5-6,4 $\mathrm{mm}$ larg., redondas a obtusas. Sementes fusiformes.

Ocorre na Bahia, Espírito Santo, Paraná, Rio de Janeiro, Santa Catarina e São Paulo (Jacques 2015). H8: Floresta ombrófila densa montana e submontana. Cresce sobre árvores no interior da mata. Encontrada com flores em fevereiro, abril e de agosto a setembro, e com frutos em fevereiro, abril e outubro.

Material selecionado - Arataca, Serra do Peito de Moça, complexo Serra das Lontras, $15^{\circ} 10^{\prime} 25^{\prime \prime} \mathrm{S}, 39^{\circ} 20^{\prime} 30^{\prime \prime} \mathrm{W}, 1000 \mathrm{~m}$ s.n.m., 12 out. 2005 (fl.), A.M. Amorim et al. 5275 (CEPEC); Buerarema, $15^{\circ} 09^{\prime} 95^{\prime \prime} \mathrm{S}, 39^{\circ} 18^{\prime} 04^{\prime \prime} \mathrm{W}, 17$ out. 2002 (fl., fr.), $P$.
Fiaschi et al. 1131 (CEPEC); Camacan, Reserva Particular do Patrimônio Natural Serra Bonita, Trilha da Bromélia, 15²3'30"S, 39³3'55"W, 850 m s.n.m., 12 fev. 2013 (fl., fr.), B.S. Gregório 218

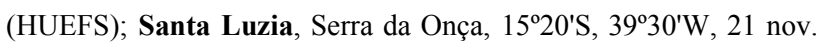
1996 (fl.), W.W. Thomas et al. 11364 (CEPEC); Una, 15¹7'36"S, 3904'31"W, 27 set. 1979 (fl.), S.A. Mori et al. 12823 (CEPEC).

Begonia radicans é uma trepadeira glabriúscula com flores vermelhas, anteras poricidas e sementes fusiformes. É semelhante a $B$. solananthera A.DC. pelo hábito, placenta partida e sementes fusiformes, diferindo pelas lâminas foliares de base levemente oblíqua (vs. base cordada), indumento glabriúsculo (vs. glabro) e flores vermelhas (vs. brancas a róseas).

29. Begonia reniformis Dryand., Trans. Linn. Soc. London 1: 161; pl. 14, fig. 1-2. 1791.

Figuras 29A-F e 30.

Subarbustos, 1-3,5 m alt., glabriúsculos a pilosos, tricomas simples e glandulares microscópicos. Caule ereto, glabrescente; entrenós 0,4-12 cm compr. Estípulas $0,5-3,5 \times 0,3-2,2 \mathrm{~cm}$, triangulares, ápice apiculado, margem inteira, carenadas, apressas, caducas. Folhas com pecíolo 5-18 cm compr., glabrescente; lâmina $6,5-28 \times 4,5-24 \mathrm{~cm}$, inteira a lobada, 3-7 lobos, recortes superficiais, não atingindo a metade da distância entre a margem e a nervura central, assimétrica, basifixa, papirácea a cartácea, transversalmente elíptica, ápices dos recortes superficiais agudos a acuminados, base cordada, margem denteada a irregularmente denticulada ou serrilhada, ciliada, pilosa, com tricomas glandulares microscópicos em ambas as faces, mais densamente na face abaxial, face adaxial glabrescente; face adaxial verde, face abaxial verde-clara a vinácea; venação actinódroma, 5-8 nervuras na base. Cimeiras 14-45 cm compr., 60-180 flores, 5-8 nós; brácteas de primeira ordem $2-5 \times 1-2,5 \mathrm{~mm}$, triangulares, persistentes. Flores estaminadas sem bractéolas; tépalas 4, alvas a róseas, as externas maiores, elípticas a ovadas, côncavas, face abaxial com tricomas glandulares microscópicos e glabrescentes, as internas elípticas a oblanceoladas, côncavas, face abaxial glabra; estames 12-32, anteras rimosas, conectivos proeminentes. Flores pistiladas com 2 bractéolas triangulares, persistentes; tépalas 5, alvas a róseas, três maiores, elípticas, face abaxial com tricomas glandulares microscópicos, glabrescente; ovário com placenta inteira. Cápsulas $0,8-1,5 \times 0,9-2,5 \mathrm{~cm}$, glabrescentes, com tricomas glandulares microscópicos; alas 3, desiguais, a maior 0,6-1,8 cm larg., ápice agudo a obtuso, as menores 1-3 mm larg., arredondadas. Sementes oblongas.

Endêmica do Brasil, é encontrada em Alagoas, Bahia, Ceará, Distrito Federal, Espírito Santo, Goiás, Minas Gerais, Paraíba, Pernambuco, Rio de Janeiro, São Paulo e Sergipe (Smith et al. 1986). C7, D6, D7, D8, E7, E8, E9, F6, F8, G7, G8, H7, H8, I8, J8: Floresta ombrófila densa montana e submontana, mata ciliar, mata de cipó, mata estacional, carrasco de 


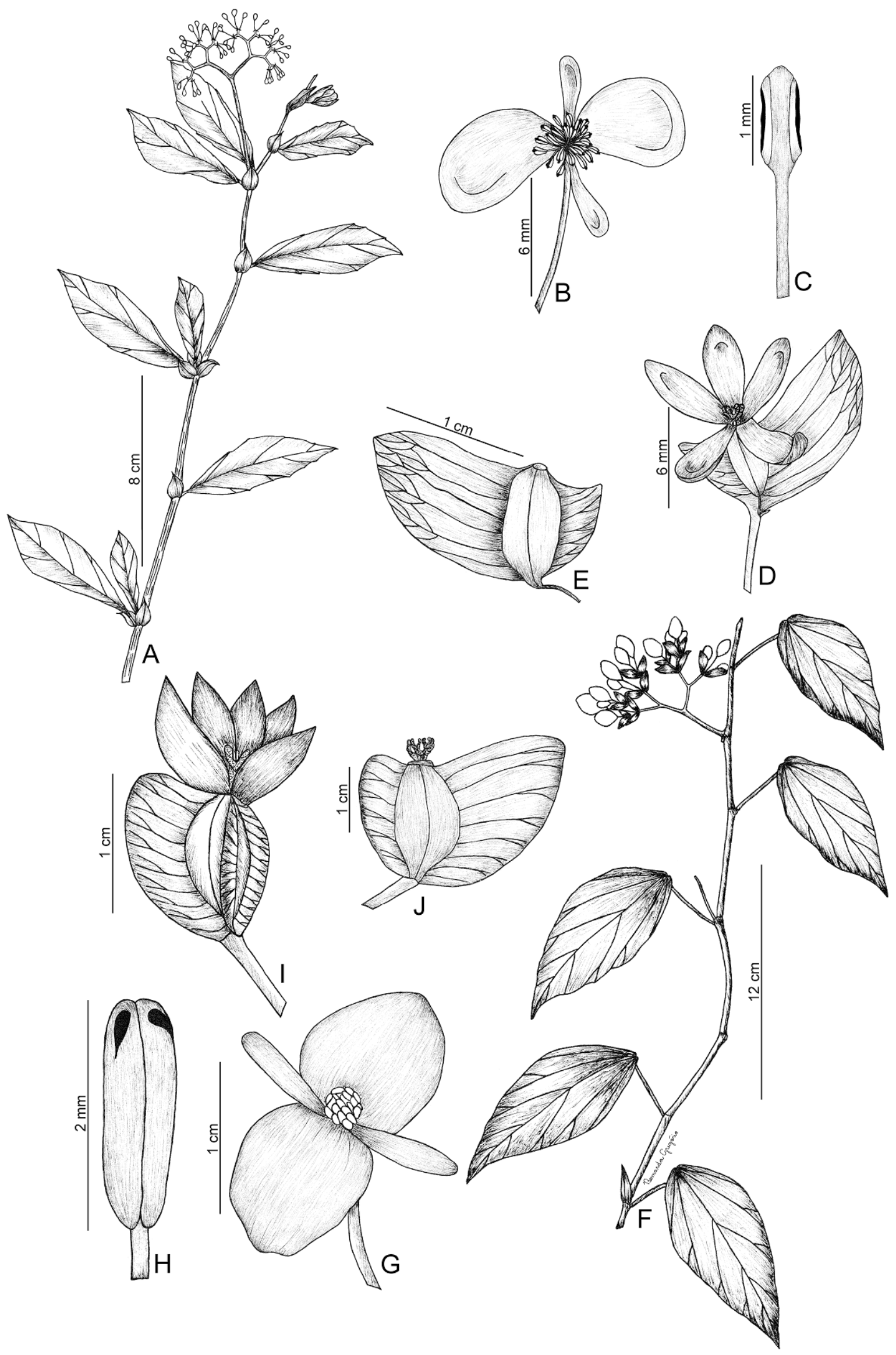

Figura 27. A-E. Begonia polygonifolia: A- ramo florido; B- flor estaminada; C- estame; D- flor pistilada; E- cápsula. F-J. B. radicans: F- ramo florido; G- flor estaminada; H- estame; I- flor pistilada; J- cápsula. (A-D- Thomas 14164; E- Santos 3383; F- Jardim 114; G-J- Gregório 218). 


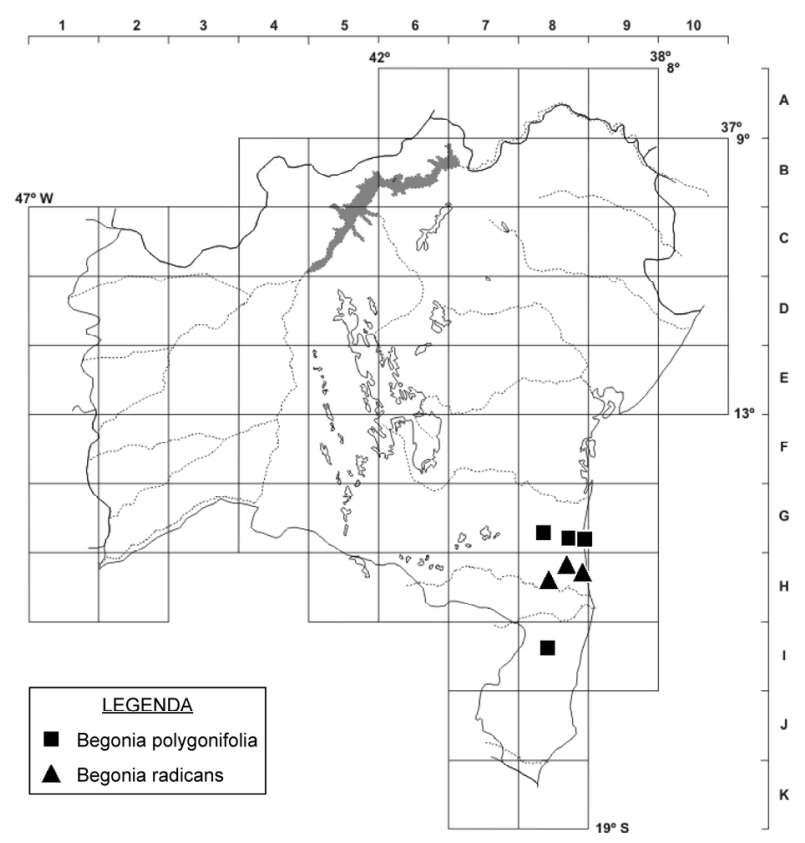

Figura 28. Mapa de distribuição de Begonia polygonifolia e $B$. radicans no estado da Bahia.

encosta, caatinga e campo rupestre. Ocorre em ambientes sombreados (p. ex.: mata de grotão) ou iluminados, no interior ou na orla da vegetação, associada a solos arenosos com afloramentos rochosos. Floresce de junho a janeiro e frutifica de janeiro a junho e de setembro a dezembro.

Material selecionado - Abaíra, estrada Piatã-Abaíra, próximo ao radiador, $13^{\circ} 17^{\prime} \mathrm{S}, 41^{\circ} 43^{\prime} \mathrm{W}, 1100 \mathrm{~m}$ s.n.m., 20 jul. 1992 (fl.), $W$. Ganev 687 (HUEFS, SP, SPF); Almadina, fazenda Beija-flor, 14²4'19"S, 39³8'14"W, 11 ago. 1972 (fl.), R.S. Pinheiro 1906 (CEPEC); Amargosa, Serra do Timbó, nas proximidades da barragem, 130.'53"S, 39³9'31"W, 21 maio 2013 (est.), B.S. Gregório 243 (HUEFS); Anguera, fazenda Retiro, próximo à rodovia do feijão, $12^{\circ} 09^{\prime} 59^{\prime \prime} \mathrm{S}, 39^{\circ} 11^{\prime} 05^{\prime \prime} \mathrm{W}, 397-500 \mathrm{~m}$ s.n.m., 31 out. 2006 (fl., fr.), D. Cardoso et al. 1403 (HUEFS); Boa Nova, $14^{\circ} 22^{\prime} \mathrm{S}, 40^{\circ} 11^{\prime} \mathrm{W}, 865 \mathrm{~m}$ s.n.m., 7 jan. 2001 (fl.), A.M. Amorim et al. 3603 (CEPEC, SP); Cachoeira, mata em frente à EMBASA, 12³2'S, 3905'W, 40-120 m s.n.m., jul. 1980 (fl.), Grupo Pedra do Cavalo 467 (ALCB, BAH, CEPEC, HRB, IPA, RB); Camacan, BR-101, 15²5'09"S, 39²9'45"W, 23 set. 1970 (fl., fr.), T.S. Santos 1146 (CEPEC); Conceição do Coité, Serra do Mucambo, 11³0'S, $39^{\circ} 12^{\prime} \mathrm{W}, 7$ set. 2012 (fl., fr.), D.N. Carvalho 104 (HUEFS); Conceição de Feira, 12³2'S, 3903'W, 31 jul. 1960 (fl.), L.R. Noblick 1975 (HUEFS, SPF); Feira de Santana, Serra de São José, $12^{\circ} 15^{\prime} \mathrm{S}, 38^{\circ} 58^{\prime} \mathrm{W}, 20$ set. 1980 (fl.), L.R. Noblick 2005 (HUEFS); Ipirá, Pau Ferro, $12^{\circ} 12^{\prime} \mathrm{S}, 39^{\circ} 37^{\prime} \mathrm{W}, 1$ out. 1985 (fl.), L.R. Noblick \& N.N.A. Santos 4392 (HUEFS); Itaberaba, pasto veadinho de baixo, fazenda Morro de Pedra, 12³1'39"S, 40¹8'25"W, 24 set. 1981 (fl.), B.C. Bastos 165 (BAH, IPA); Itagibá, mata da Botinha, $14^{\circ} 10^{\prime} 53^{\prime \prime} \mathrm{S}$, 3942'27"W, 28 set. 2008 (fl., fr.), C.E. Ramos et al. 552 (ALCB); Itamaraju, fazenda Novo Pau-Brasil, Morro Pescoço, 1659'23"S, 39³4'40"W, 11 maio 2013 (fr.), B.S. Gregório 240 (HUEFS); Itarantim, Serra da Felicíssima, fazenda Bom Jardim, 180-300 m s.n.m., $15^{\circ} 49^{\prime} 01,2^{\prime \prime S}, 40^{\circ} 06^{\prime} 57,5^{\prime \prime} \mathrm{W}, 7$ out. 2003 (fl.), A. Salino et al.
9126 (BHCB, MBM); Itatim, Morro da Torre, $12^{\circ} 43^{\prime} \mathrm{S}, 39^{\circ} 42^{\prime} \mathrm{W}$, 330 m s.n.m., 9 nov. 1996 (fl., fr.), E. Melo et al. 1834 (CEPEC, HUEFS); Ituaçu, $13^{\circ} 48^{\prime} 48^{\prime \prime} \mathrm{S}, 41^{\circ} 17^{\prime} 48^{\prime \prime} \mathrm{W}, 18$ ago. 1988 (fl.), Eggli 1192 (CEPEC); Jacobina, ca. $21 \mathrm{~km}$ a oeste de Jacobina, $11^{\circ} 05^{\prime} 21^{\prime \prime S}, 40^{\circ} 23^{\prime 2} 23^{\prime \prime W}, 815$ m s.n.m., 25 jun. 1999 (fl.), F. França et al. 3140 (HUEFS); Miguel Calmon, Serra das Sete Passagens, Parque Estadual das Sete Passagens, próximo à sede do parque,

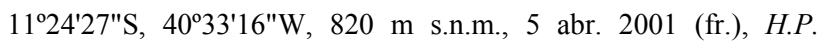
Bautista et al. 3030 (CEPEC, HRB, HUEFS); Milagres, fazenda Bom Jesus, 1252'12"S, 3951'32"W, 7 dez. 1969 (fr.), A.L. Costa s.n. (ALCB 2896); Morro do Chapéu, área da Cachoeira do Ferro Doido, 11'37'32"S, 4059'53"W, 29 jan. 2013 (fr.), B.S. Gregório 213 (HUEFS); Mundo Novo, fazenda Jequitibá, $12^{\circ} 02^{\prime} \mathrm{S}, 40^{\circ} 29^{\prime} \mathrm{W}$, 604 m s.n.m., 26 ago. 2006 (fl.), P.A. Melo 107 (HUEFS); Pindobaçu, Serra da Fumaça, 10³8'54"S, 40²2'34"W, 26 out. 2008 (fl., fr.), L.A. Sousa 165 (HUEFS); Porto Seguro, Km 11 da rodovia Porto Seguro-Eunápolis, 16²6'59"S, 3903'53"W, 22 set. 1971 (fl., fr.), T.S. Santos 1989 (CEPEC); Ruy Barbosa, Serra do Orobó, Pátio das orquídeas, $12^{\circ} 18^{\prime} 03^{\prime \prime S}, 40^{\circ} 28^{\prime} 42^{\prime \prime W}, 628$ m s.n.m., 20 ago. 2005 (fl., fr.), D. Cardoso et al. 754 (HUEFS); Santa Cruz Cabrália, área da Estação Ecológica Pau-Brasil, $16^{\circ} 23^{\prime} \mathrm{S}, 39^{\circ} 08^{\prime} \mathrm{W}$, ca. 40 m s.n.m., 8 out. 1984 (fl., fr.), F.S. Santos et al. 417 (CEPEC, MBM); Senhor do Bonfim, Estiva, Serra de Santana na margem da trilha, 10²7'41"S, 40¹1'22"W, 10 set. 2004 (fl.), V.J. Santos et al. 319 (HUEFS); Wenceslau Guimarães, 13⒋1'13"S, 39²8'46"W, 24 maio 2013 (est.), B.S. Gregório 254 (HUEFS).

Begonia reniformis caracteriza-se pelas estípulas triangulares e caducas, lâmina foliar transversalmente elíptica, inteira a irregularmente lobada e pela ala maior da cápsula com ápice agudo a obtuso. Possui elevada variação fenotípica, especialmente quanto à forma e subdivisão da lâmina foliar, que pode ser inteira ou possuir diversos lobos, quanto ao tipo de margem e forma do ápice da ala maior da cápsula.

30. Begonia ruhlandiana Irmsch., Bot. Jahrb. Syst. 76: 67; pl. 4. 1953.

Figuras 29G-K e 30.

Subarbustos, $0,6-3 \mathrm{~m}$ alt., pubescentes a tomentosos, tricomas estrelados. Caule ereto, glabrescente; entrenós 0,4-9 cm compr. Estípulas 0,7$2,8 \mathrm{~cm} \times 4-8 \mathrm{~mm}$, triangulares, ápice apiculado, margem inteira, apressas, caducas. Folhas com pecíolo 1-3,9 cm compr., tomentoso; lâmina 7,7-17,8 × 3,4-9 $\mathrm{cm}$, inteira, levemente assimétrica, basifixa, crassa a coriácea, elíptica a oblonga, ápice agudo a obtuso, base arredondada a obtusa, margem inteira ou irregularmente dentada a irregularmente denticulada, tomentosa a quase lanosa em ambas as faces, mais densamente na face abaxial, glabrescente na face adaxial; face adaxial verde, face abaxial verde-pálida; venação craspedódroma. Cimeiras 23,2-43,8 cm compr., 28-70 flores, 4-6 nós; brácteas de primeira ordem 6-9 × 3-4,5 mm, obovadas, caducas. Flores estaminadas sem bractéolas; tépalas 2, alvas a róseas, 5,2-7 × 4,7-6 mm, largamente ovadas a orbiculares, face abaxial glabrescente; estames 12-20, anteras rimosas, conectivos proeminentes. Flores pistiladas 


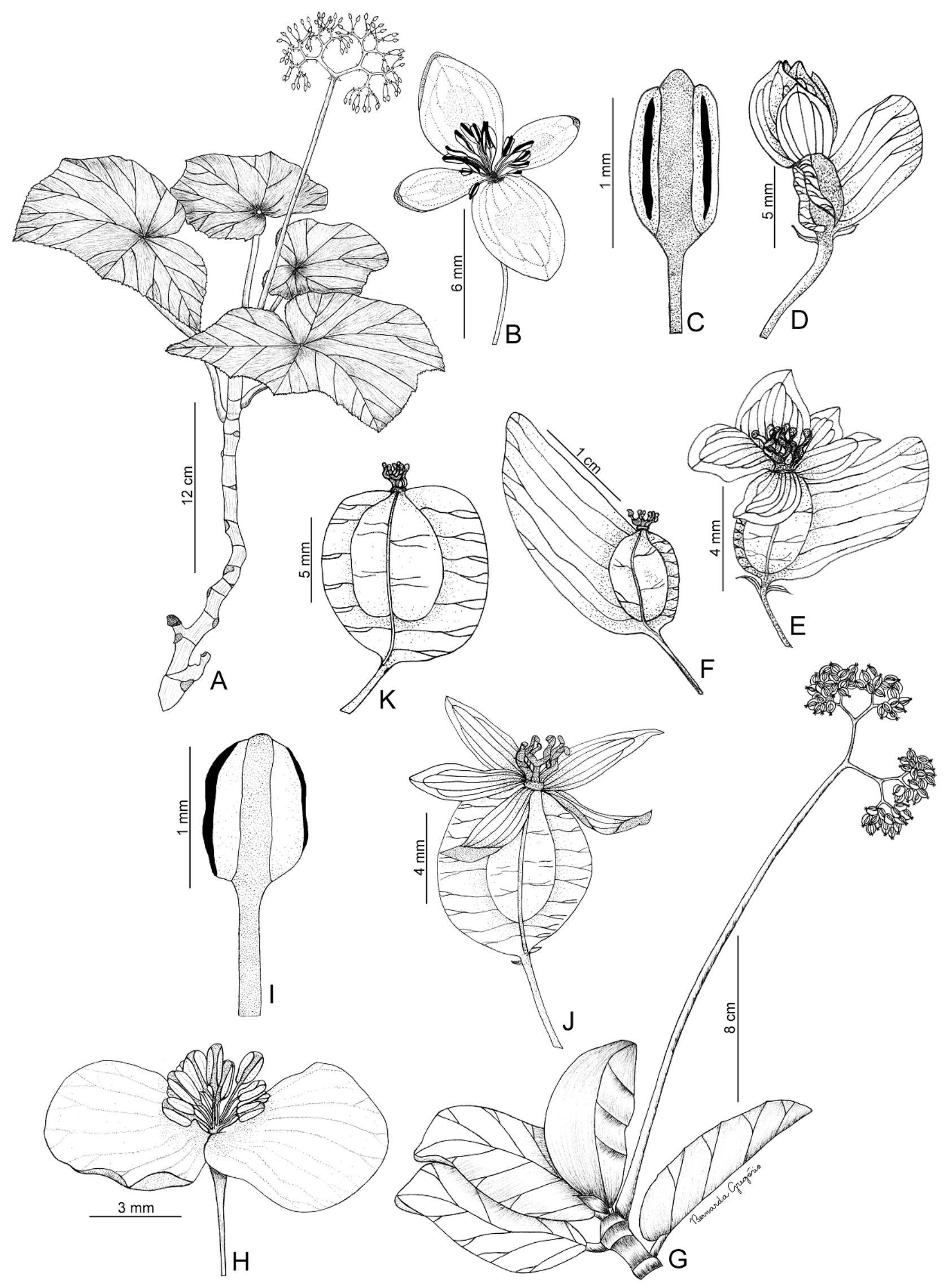

Figura 29. A-F. Begonia reniformis: A- ramo florido; B- flor estaminada; C- estame; D- flor pistilada jovem; E-flor pistilada em antese; F- cápsula. G-K. B. ruhlandiana: G- ramo com frutos; H- flor estaminada; I- estame; J- flor pistilada; K- cápsula. (A-C- Melo 2210; D, E- Ganev 687; F- Bautista 3030; G, K- Melo 3458; H, I- Stannard 51731; J- Hatschbach 39615). 


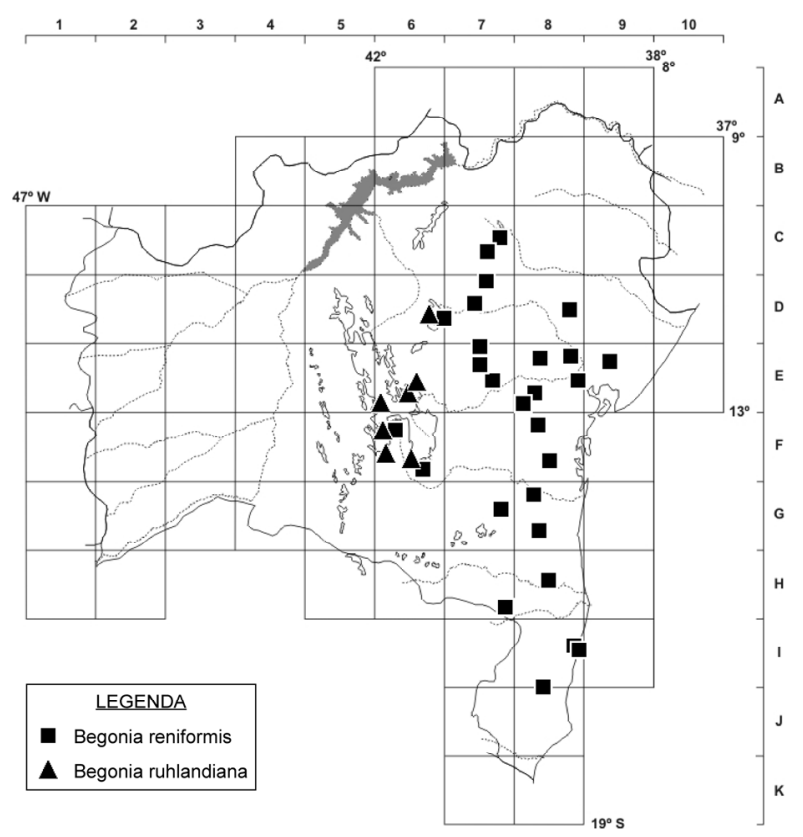

Figura 30. Mapa de distribuição de Begonia reniformis e B. ruhlandiana no estado da Bahia.

com 2 bractéolas estreitamente elípticas, caducas; tépalas 5(6), alvas a róseas, duas ligeiramente maiores, elípticas a ovadas, face abaxial glabrescente; ovário com placenta inteira. Cápsulas $0,5-1,3 \times 0,5-1 \mathrm{~cm}$, glabrescentes, sem tricomas glandulares microscópicos; alas 3, subiguais, a maior 2,5-4 mm larg., ápice arredondado, as menores 1-2 mm larg., arredondadas. Sementes oblongas.

Endêmica da Bahia (Jacques 2015), é restrita à região da Chapada Diamantina. D6, E6, F6: Campos gerais, mata ciliar, cerrado, carrasco e campo rupestre. Cresce exposta ao sol, em solos arenosos ou litólicos, ou associada a afloramentos rochosos, sobre ou entre fendas nas rochas. Floresce de fevereiro a junho e de setembro a dezembro; frutifica de janeiro a abril, em junho e de outubro a dezembro.

Material selecionado - Serra do Sincorá, 1100 m s.n.m., nov. 1906 (fl., fr.), E. Ule 7122 (holótipo de B. ruhlandiana: B [foto]); Abaíra, Salão, $9 \mathrm{~km}$ de Catolés na estrada para Inúbia, $13^{\circ} 15^{\prime} \mathrm{S}$, 41 ${ }^{\circ} 53^{\prime}$ W, 1100-1200 m s.n.m., 28 dez. 1991 (fl.), R.M. Harley et al. 50523 (HUEFS); Ibicoara, Chapada Diamantina, caminho para a

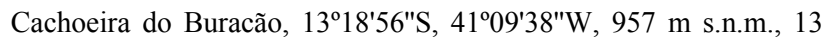
out. 2007 (fr.), M.L. Guedes et al. 13893 (ALCB, MBM); Lençóis, Serra Larga ("Serra Larguinha"), a oeste de Lençóis, próximo de Caeté-Açu, 12³3'47"S, 41ํ2'24"W, 1400 m s.n.m., 19 dez. 1984 (fl., fr.), R.M. Harley et al. 7216 (HUEFS, SPF); Morro do Chapéu, Morrão, próximo à Torre, $11^{\circ} 35^{\prime} 00^{\prime \prime S}, 41^{\circ} 12^{\prime} 26^{\prime \prime} \mathrm{W}, 1304$ m s.n.m., 28 jan. 2013 (est.), B.S. Gregório \& L. Rocha 211 (HUEFS); Mucugê, Parque Nacional da Chapada Diamantina, Serra do Esbarrancado, $12^{\circ} 43^{\prime} 51^{\prime \prime S}, 41^{\circ} 30^{\prime} 33^{\prime \prime W}, 1500$ m s.n.m., 16 abr. 2005 (fl.), A.A. Conceição \& D. Cardoso 1264 (HUEFS); Palmeiras, próximo à localidade de Caeté-Açu, Cachoeira da Fumaça, 12³6'01"S, 412ㄱ'17"W, 11 out. 1987 (fl.), L.P. Queiroz et al. 1944 (CEPEC, HUEFS); Rio de Contas, Serra Marsalina (Serra da antena de TV), 1335'34"S, 41 49'55"W, 1020 m s.n.m., 18 nov. 1996 (fr.), R.M. Harley et al. PCD 4485 (ALCB, HUEFS, SPF).
Begonia ruhlandiana é facilmente reconhecida pelo indumento formado por tricomas estrelados brancos ou ferrugíneos, pelas folhas com lâminas simétricas a levemente assimétricas, elípticas a oblongas, de base arredondada a obtusa, com face adaxial verde e abaxial verde-pálida e venação craspedódroma. A espécie apresenta, em geral, flores estaminadas com duas tépalas, mas foi encontrado um espécime (Guedes et al. 19288) com flores estaminadas com quatro tépalas. A espécie possui adaptações subxerofíticas, encontradas também em $B$. fellereriana, $B$. grisea e $B$. pernambucensis: maior espessamento do caule e da lâmina foliar, cutícula com denso revestimento pubescente a tomentoso e folhas capazes de se enrolar, mantendo os estômatos protegidos (Irmscher 1953; Duarte 1961; Brade 1971). Begonia ruhlandiana difere dessas espécies xerofíticas, no entanto, pela lâmina foliar elíptica a oblonga com base arredondada a obtusa e venação craspedódroma.

31. Begonia russelliana L.B.Sm. ex S.F.Sm. \& Wassh., Selbyana 20(1): 25; fig.8. 1999.

Figuras 31A-G e 32

Ervas, 6-30 cm alt., pilosas a tomentosas, tricomas simples, finos, de base espessa e tricomas glandulares microscópicos. Caule prostrado ou decumbente, piloso; entrenós 0,6-2,2 cm compr. Estípulas 0,8-2 $\times$ 0,4-1 cm, ovadas a lanceoladas, ápice apiculado, margem inteira, carenadas, apressas, persistentes. Folhas com pecíolo 3,5-22 cm compr., piloso a tomentoso; lâmina 3-18 $\times 2,6-22 \mathrm{~cm}$, inteira, levemente assimétrica, basifixa, papirácea, arredondada a transversalmente elíptica, ápice arredondado a curtamente acuminado, base cordada, margem crenada a crenulada, ciliada, pilosa em ambas as faces, com pilosidade concentrada nas nervuras da face abaxial; face adaxial verde a vinácea, face abaxial verde-clara a vinácea; venação actinódroma, 7-9 nervuras na base. Cimeiras 5-25,5 cm compr., 3-30 flores, 1-4 nós; brácteas de primeira ordem, 2,5-7 $\times$ 1,5-4 mm, ovadas, persistentes. Flores estaminadas sem bractéolas; tépalas 4, alvas, as externas maiores, orbiculares a largamente ovadas, face abaxial com esparsos tricomas glandulares microscópicos, as internas oblanceoladas, face abaxial glabra; estames 610, anteras rimosas, conectivos proeminentes. Flores pistiladas com 2 bractéolas lanceoladas a oblanceoladas, persistentes; tépalas 5, alvas, duas maiores, elípticas a obovadas, face abaxial com esparsos tricomas glandulares microscópicos; ovário com placenta inteira. Cápsulas $0,6-1,5 \times 0,7-1,6 \mathrm{~cm}$, com esparsos tricomas glandulares microscópicos a glabras; alas 3, desiguais, a maior 2,6-7 mm larg., ápice arredondado a obtuso, as menores 2-4 mm larg., redondas a obtusas. Sementes oblongas.

Endêmica da Bahia (Jacques 2015). F8: Floresta ombrófila densa montana e submontana. Cresce no interior da mata sobre rochas ou em solos ricos em húmus; é também encontrada em plantações de cacau. 


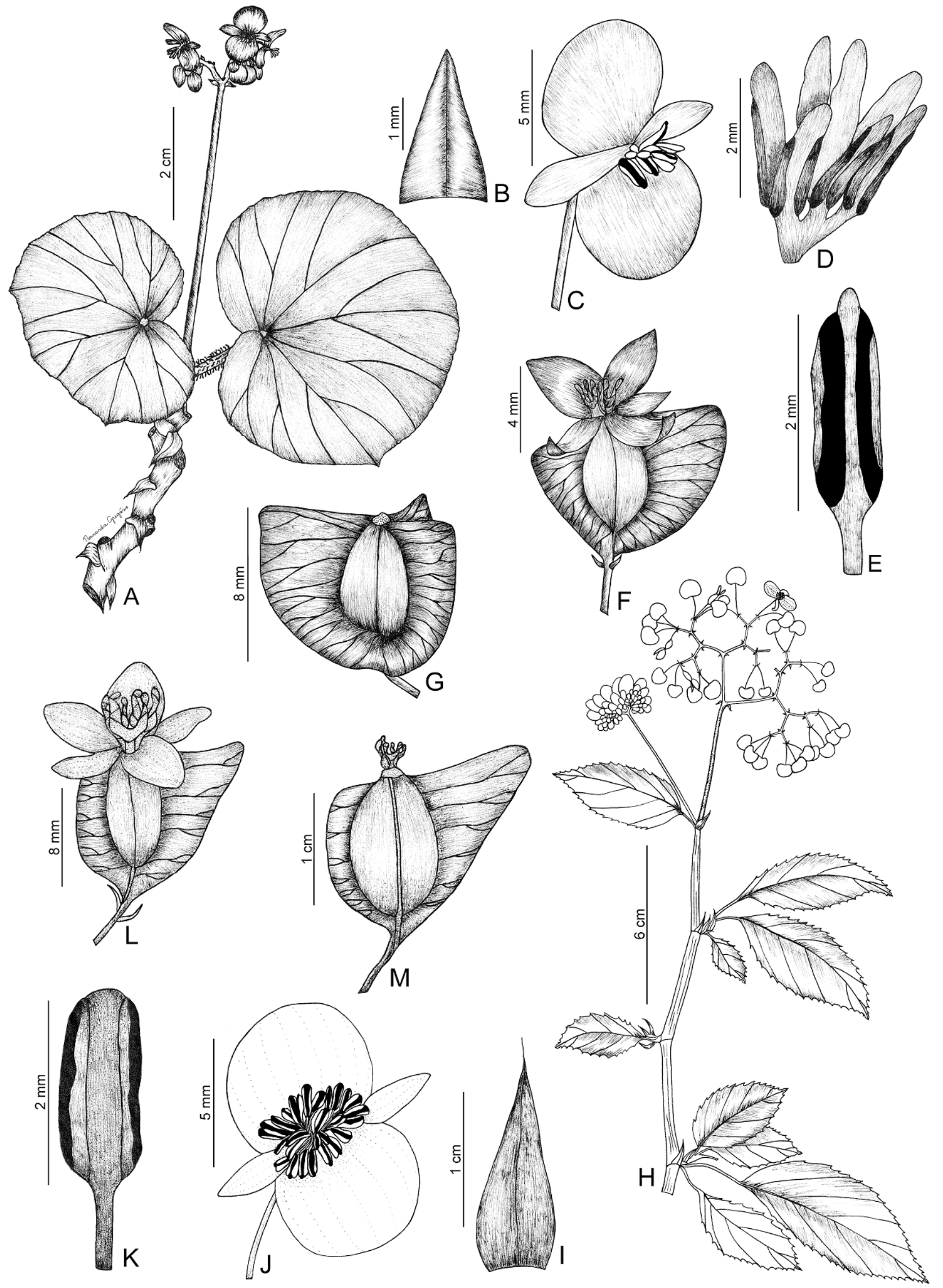

Figura 31. A-G. Begonia russelliana: A- ramo florido; B- bractéa de $1^{\mathrm{a}}$ ordem; C- flor estaminada; D- androceu com andróforo; E- estame; F- flor pistilada; G- cápsula. H-M. B. saxicola: H- ramo florido; I- estípula; J- flor estaminada; K- estame; L- flor pistilada; M- cápsula. (A- Pinheiro 2021; B-F- Gregório 248; G- Gregório 247; H-K- Carneiro-Torres 519; L- Salino 9127; M- van den Berg 856). 
Foi encontrada com flores em janeiro, março, maio, julho, setembro, outubro e dezembro; coletada com frutos em março, maio, julho, outubro e dezembro.

Material selecionado - Gandu, estrada a Ituberá, 13\%44'38"S, 39²9'12"W, 21 out. 1970 (fl., fr.), T.S. Santos 1160 (CEPEC); Valença, Reserva Particular do Patrimônio Natural Água Branca, $13^{\circ} 19^{\prime} 44^{\prime \prime S}, 39^{\circ} 05^{\prime} 25^{\prime \prime} \mathrm{W}, 220$ m s.n.m., 22 maio 2013 (fl., fr.), B.S Gregório 247 (HUEFS); ib., fazenda Floresta, 13²2'13"S, 39 $04^{\prime} 23 " \mathrm{~W}, 50 \mathrm{~m}$ s.n.m., 24 abr. 1976 (fl.), G.F. Russell s.n. (holótipo de B. russelliana: US 324375[foto], isótipo: US 324414 [foto]); Wenceslau Guimarães, Estação Ecológica Estadual de Wenceslau Guimarães, trilha da Petioba, 1334'49"S, 39² $42^{\prime} 17^{\prime \prime} \mathrm{W}$, 450-650 m s.n.m., 24 maio 2013 (bot., fl., fr.), B.S. Gregório 248 (CEPEC, HUEFS).

Begonia russelliana é uma planta pequena, reconhecida pelo caule prostrado a decumbente, indumento vináceo a translúcido, com lâminas foliares arredondadas a transversalmente elípticas, com margem crenada a crenulada e ciliada. Verificou-se no campo que as lâminas foliares de $B$. russelliana variam de coloração, do verde ao vináceo em indivíduos a poucos centímetros de distância. Além disso, a quantidade de indumento também é bastante variável, sendo encontrados desde indivíduos pilosos a tomentosos. Assemelha-se a $B$. subacida pelo hábito herbáceo, tipo de indumento, forma das lâminas foliares e cimeiras com número proporcional de flores. Diferencia-se de $B$. subacida pelas brácteas de primeira ordem maiores $(2,5-7 \times 1,5-4 \mathrm{~mm}$ vs. $1-1,5 \times 0,4-0,7$ $\mathrm{mm}$ ) e ovadas (vs. lanceoladas) e o número menor de estames (6-10 vs. 28-32), além da presença de andróforo (vs. ausência) e anteras maiores que o filete (vs. iguais ou menores).

32. Begonia saxicola A.DC., Ann. Sci. Nat., Bot., sér. 4, 11: 144. 1859.

Figuras $31 \mathrm{H}-\mathrm{M}$ e 32.

Ervas ou subarbustos, $0,4-1,8 \mathrm{~m}$ alt., glabriúsculos a glabros, esparsos tricomas simples e glandulares microscópicos. Caule ereto a escandente, glabriúsculo a glabro, com tricomas glandulares microscópicos; entrenós $(0,5-) 1-6,5(-10) \mathrm{cm}$ compr. Estípulas 0,7$1,6 \mathrm{~cm} \times 3-5 \mathrm{~mm}$, lanceoladas, ápice apiculado, margem inteira, carenadas, apressas, persistentes. Folhas com pecíolo 0,3-3,6 cm compr., glabriúsculo, com tricomas glandulares microscópicos a glabro; lâmina 3,5-14 × 1,6-4,8 cm, inteira, levemente assimétrica, basifixa, membranácea, elíptica a obovada, ápice agudo a acuminado, base oblíqua, margem serreada a serrilhada ou crenado-dentada, ciliada, com esparsos tricomas glandulares microscópicos a glabra em ambas as faces; face adaxial verde, face abaxial verde-clara; venação craspedódroma. Cimeiras 5-15 cm compr., 9-40 flores, 2-5 nós; brácteas de primeira ordem $2-5 \times 0,7-2 \mathrm{~mm}$, lanceoladas, persistentes. Flores estaminadas sem bractéolas; tépalas (2)4, alvas, as externas maiores, orbiculares a ovadas, face abaxial com tricomas glandulares microscópicos a glabra, as internas elípticas, face abaxial glabra;

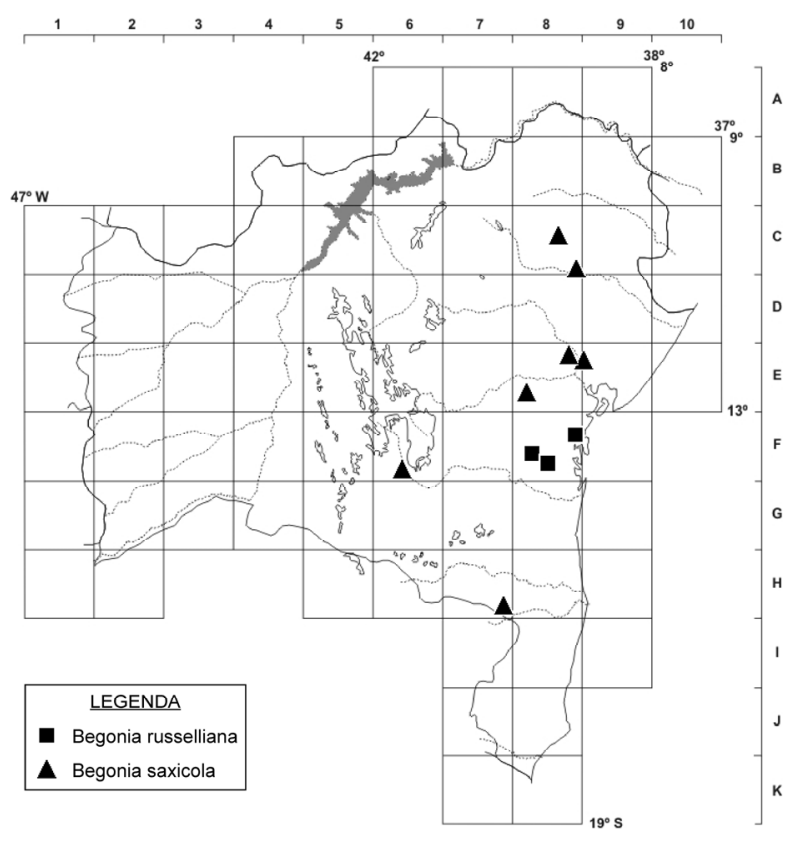

Figura 32. Mapa de distribuição de Begonia russelliana e B. saxicola no estado da Bahia.

estames 18-42, anteras rimosas, conectivos proeminentes. Flores pistiladas com 2 bractéolas lanceoladas, persistentes; tépalas 5 , alvas a róseas, duas maiores, elípticas, ovadas a largamente ovadas, face abaxial com tricomas glandulares microscópicos a glabra; ovário com placenta partida. Cápsulas 1,2-1,6 $\times 1,2-2,5 \mathrm{~cm}$, com tricomas glandulares microscópicos a glabras; alas 3, desiguais, a maior $0,7-1,5 \mathrm{~cm}$ larg., ápice agudo a obtuso, as menores 1-4 mm larg., arredondadas. Sementes oblongas.

Endêmica do Brasil, esta espécie é encontrada no Acre, Alagoas, Bahia, Ceará, Pará, Paraíba, Pernambuco (Jacques 2015) e Sergipe. C8, E8, F6, H7: Caatinga arbóreo-arbustiva, mata ciliar e floresta estacional. Ocorre em encostas de morros ou em afloramentos graníticos ou quartzíticos, em solos úmidos, arenosos ou pedregosos. Floresce e frutifica de junho a janeiro.

Material selecionado - Anguera, fazenda Retiro, próxima à Rodovia do Feijão, 12 09'59"S, 39¹1'05"W, 397-500 m s.n.m., 31 out. 2006 (fl., fr.), D. Cardoso et al. 1409 (HUEFS); Feira de Santana, Serra de São José, $12^{\circ} 15^{\prime}$ S, 38 $38^{\circ} 58^{\prime} \mathrm{W}, 20$ set. 1980 (fl., fr.), L.R. Noblick 2017 (HUEFS, SPF); Itarantim, Serra da Felicíssima,

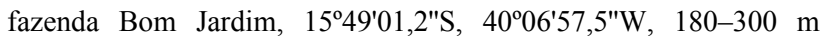
s.n.m., 7 out. 2003 (fl.), A. Salino et al. 9127 (BHCB, HUEFS, MBM); Itatim, Morro do Quixaba. $12^{\circ} 44^{\prime} \mathrm{S}, 39^{\circ} 47^{\prime} \mathrm{W}, 366 \mathrm{~m}$ s.n.m., 14 dez. 1996 (fr.), E. Melo et al. 1882 (HRB, HUEFS, MBM); Monte Santo, Morro das Orações, 10²6'22"S, 39²0'19"W, $760 \mathrm{~m}$ s.n.m., 24 jun. 2005 (fl.), D.S. Carneiro-Torres et al. 519 (HUEFS); Quijingue, Serra das Candeias, ca. $5 \mathrm{~km}$ a oeste do povoado Quixaba do Mandacaru, no limite com o município de Tucano, $10^{\circ} 55^{\prime} 20^{\prime \prime S}, 39^{\circ} 04^{\prime} 59^{\prime \prime} \mathrm{W}, 400-630$ m s.n.m., 8 jul. 2006 (fl.), $D$. Cardoso \& T.M. Santana 1305 (HUEFS); Rio de Contas, distrito de Boa Sentença, nas margens do riacho, próximo à Cachoeirinha,

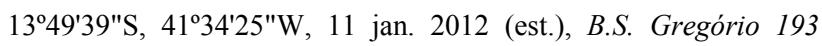
(HUEFS). 
Material adicional - BRASIL. CEARÁ: Serra do Araripe, s.d. (fl. fr.), G. Gardner 2029 (holótipo de B. saxicola: K [foto]). SERGIPE: Poço Verde, ago. 2010 (fl.), E.V.R. Ferreira 152 (ASE).

Begonia saxicola caracteriza-se por caule e ramos geralmente esbranquiçados e estriados, pelos ramos curtos revestidos por um tufo de estípulas lanceoladas e persistentes, pelas brácteas e bractéolas das flores pistiladas persistentes e pelas flores estaminadas frequentemente com quatro tépalas. Assemelha-se a $B$. ulmifolia pelo hábito, caule, ramos estriados e angulosos e pela forma das lâminas foliares. Contudo, difere daquela espécie pelo indumento glabriúsculo passando a glabra (vs. piloso e persistente), caule geralmente esbranquiçado quando vivo (vs. verde com nuances vináceas), estípulas lanceoladas (vs. estreitamente triangulares), flores estaminadas e pistiladas com tépalas com tricomas glandulares microscópicos a glabras na face abaxial (vs. pilosas).

33. Begonia saxifraga A.DC., Ann. Sci. Nat., Bot., sér. 4, 11: 138. 1859.

Figuras $33 \mathrm{~A}-\mathrm{E}$ e 34.

Ervas, 12-20 cm alt., pilosas, tricomas simples, longos e finos, tricomas curtos de base espessa e tricomas glandulares microscópicos. Caule decumbente, piloso; entrenós 0,1-0,3 cm compr. Estípulas $1,2-2,3 \times 0,6-10 \mathrm{~cm}$, ovadas, ápice apiculado, margem ciliada, apressas, persistentes. Folhas com pecíolo 2,5-9,5 cm compr., pilosos; lâmina 3-9 × 2,5-5 cm, inteira, assimétrica, basifixa, membranácea, ovada, ápice agudo a acuminado, base cordada, margem levemente ondulada, crenulada, ciliada, pilosa em ambas as faces, mais densamente na face abaxial, tricomas curtos somente na face adaxial; face adaxial verde, face abaxial verde-clara; venação actinódroma, 7-9 nervuras na base. Cimeiras 9,3-42 cm compr., 8-20 flores, 3-5 nós; brácteas de primeira ordem 1-3 × 0,4-0,7 mm, lanceoladas, persistentes. Flores estaminadas sem bractéolas; tépalas 4 , alvas a róseas, as externas maiores, elípticas, face abaxial glabra, as internas oblongas, face abaxial glabra; estames ca. 14, anteras rimosas, conectivos proeminentes. Flores pistiladas com 2 bractéolas lanceoladas, caducas; tépalas 5, alvas, três maiores, ovadas a oblanceoladas, face abaxial com esparsos tricomas glandulares microscópicos; ovário com placenta inteira. Cápsulas $6-8 \mathrm{~mm} \times 0,8-1,2 \mathrm{~cm}$, sem tricomas glandulares microscópicos, glabras; alas 3, desiguais, a maior 4-6 mm larg., ápice arredondado a obtuso, as menores 2-3 mm larg., redondas. Sementes oblongas.

Endêmica da Bahia (Jacques 2015). H8: Floresta ombrófila densa montana e submontana. Foi encontrada com flores em janeiro.

Material selecionado - Arataca, Serra das Lontras, fazenda

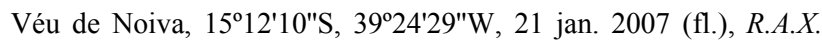
Borges et al. 597 (CEPEC); Ilhéus, costa marítima, próximo de Almada, $14^{\circ} 47^{\prime} 20^{\prime \prime} \mathrm{S}, 39^{\circ} 02^{\prime} 58^{\prime \prime} \mathrm{W}$, s.d. (fl.), C.F.P. Martius s.n. (M 145736 [foto]).
Begonia saxifraga é uma erva pequena, decumbente, com lâminas foliares ovadas, ápice acuminado e margem crenulada levemente ondulada. A espécie era conhecida somente pelo material-tipo e por coletas antigas em Ilhéus, mas foi encontrada recentemente em Arataca. Assemelha-se a B. subacida pelo hábito herbáceo, caule decumbente, estípulas ovadas e lâminas foliares com ápice acuminado. Entretanto, B. saxifraga difere daquela espécie pelas estípulas com margem ciliada (vs. inteira), lâminas foliares ovadas (vs. arredondadas a transversalmente elípticas) e tépalas estaminadas externas elípticas (vs. orbiculares a largamente ovadas).

34. Begonia schlumbergeriana Lem., Ill. Hort. 5, Misc.: 61. 1858.

Arbustos [alt., não informada], pilosos, tricomas estrelados. Caule glabro; entrenós [não informados]. Estípulas [medidas não informadas], obliquamente deltoides. Folhas com pecíolo 17,5-22,5 cm compr., ferrugíneo-panoso; lâmina ca. $15 \mathrm{~cm}$ larg., subinteira, basifixa, carnosa, arredondada a reniforme, profundamente cordada, margem sinuosa-dentada quando jovem, inteira quando adulta, glabrescente na face adaxial, ferrugíneo-panosa na face abaxial; face adaxial verde com indumento alvo; venação actinódroma, 7 nervuras na base. Cimeiras [medida não informada], multifloras; brácteas caducas. Flores estaminadas [não descritas]. Flores pistiladas com bractéolas ca. $3 \mathrm{~mm}$ compr., lineares, estreitas, caducas; tépalas 6-7, obovado-oblongas; ovário com placenta inteira. Cápsulas ca. $12 \times 8 \mathrm{~mm}$, com esparsos tricomas glandulares microscópicos; alas 4 ou 5, desiguais, uma um pouco maior que as demais, arredondada a ovada, dentada. Sementes [não informadas].

Begonia schlumbergeriana assemelha-se a $B$. grisea pelos tricomas estrelados, forma das folhas e cimeiras multifloras, diferindo pelos estiletes em número de 4 ou 5 (vs. 3), ovário 4- ou 5-locular (vs. 3locular) e cápsulas 4- ou 5-aladas (vs. 3-aladas).

Begonia schlumbergeriana é conhecida somente por sua descrição original, a qual indica ter sido a planta coletada na Bahia e enviada para a Europa, onde foi disseminada entre casas de cultivo. Descrita com base em um espécime cultivado, o autor não indicou material-testemunho, assim como o herbário onde ele estaria depositado, além de não ter apresentado uma ilustração ou fotografia da planta. $\mathrm{Na}$ revisão de Begoniaceae (Smith et al. 1986), há uma fotografia pouco nítida do provável holótipo de $B$. schlumbergeriana, constituído por três flores pistiladas e duas cápsulas, além de uma extensa descrição e desenhos do ovário e do estilete. Lemaire geralmente depositava seus exemplares no Museu Nacional de História Natural de Paris (P). Esforços infrutíferos foram feitos a fim de localizar o material. Há a possibilidade do material-tipo estar perdido na coleção do $\mathrm{P}$ assim como pode estar em outro herbário da 
Europa. Dessa forma, B. schlumbergeriana está sendo considerada neste trabalho como táxon duvidoso.

35. Begonia subacida Irmsch., Bot. Jahrb. Syst. 78: 183.1959.

Figuras 33F-I e 34

Ervas, $10-30 \mathrm{~cm}$ alt., pilosas a tomentosas, tricomas simples, finos, de base espessa e tricomas glandulares microscópicos. Caule prostrado ou decumbente, piloso; entrenós 0,8-2,5 cm compr. Estípulas $1,2-2,2 \times 0,6-1,3 \mathrm{~cm}$, ovadas, ápice apiculado, margem inteira, carenadas, apressas, persistentes. Folhas com pecíolo 5,5-15 cm compr., piloso a tomentoso; lâmina $7-12 \times 9-15 \mathrm{~cm}$, inteira, levemente assimétrica, basifixa, membranácea, arredondada a transversalmente elíptica, ápice arredondado a curtamente acuminado, base cordada, margem crenulada, ciliada, pilosa em ambas as faces, face abaxial com pilosidade concentrada nas nervuras; face adaxial verde, face abaxial vinácea; venação actinódroma, 8 ou 9 nervuras na base, verde-claras. Cimeiras 19-34 cm compr., 24-40 flores, 4 ou 5 nós; brácteas de primeira ordem $1-1,5 \times 0,4-0,7 \mathrm{~mm}$, lanceoladas, persistentes. Flores estaminadas sem bractéolas; tépalas 4, alvas, as externas maiores, orbiculares, face abaxial com esparsos tricomas glandulares microscópicos, as internas oblanceoladas, face abaxial glabra; estames 28-32, anteras rimosas, conectivos proeminentes. Flores pistiladas [não vistas, obtidas a partir de botões], com 2 bractéolas lanceoladas, persistentes; tépalas 5, alvas, duas maiores, elípticas a obovadas, face abaxial com esparsos tricomas glandulares microscópicos; ovário com placenta inteira. Cápsulas ca. $8 \mathrm{~mm} \times 1,7 \mathrm{~cm}$, [obtidas por foto do holótipo]; alas 3, desiguais, a maior ca. $7 \mathrm{~mm}$ larg., ápice arredondado, as menores ca. $4 \mathrm{~mm}$ larg., redondas. Sementes oblongas [obtidas pelo protólogo].

Endêmica da Bahia (Jacques 2015). G8, H8: Floresta ombrófila densa submontana. Habita solos ricos em húmus. Foi encontrada com flores e frutos em outubro.

Material selecionado - jan. 1818 (fl., fr.), C.F.P. Martius s.n. (holótipo de B. subacida: M 145739 [foto], isótipo: NY 118649 [foto]); Itapé, fazenda Santa Helena, 14 $53^{\circ} 54^{\prime \prime} \mathrm{S}, 39^{\circ} 25^{\prime} 16^{\prime \prime} \mathrm{W}, 20$ dez. 1972 (fl.), R.S. Pinheiro 2021 (CEPEC); Jussari, fazenda Teimoso, Km 9 da rodovia Jussari-Palmira, lado esquerdo, 15¹1'29"S, 39²9'43"W, 26 fev. 1987 (est.), L.A. Mattos Silva et al. 2152 (CEPEC).

Begonia subacida assemelha-se a B. itaguassuensis pelo caule e forma das lâminas foliares, mas é prontamente diferenciada daquela espécie pelas margens foliares crenadas a crenuladas (vs. denticuladas), cimeiras com 5-40 flores (vs. 50-200 flores) e tépalas estaminadas externas orbiculares a largamente ovadas (vs. ovadas a elípticas). Begonia subacida assemelha-se também a $B$. russelliana (ver comentários em B. russelliana).
36. Begonia sylvatica Meisn. ex A.DC., Ann. Sci. Nat., Bot., sér. 4, 11: 138. 1859.

Figuras $35 \mathrm{~A}-\mathrm{F}$ e 36.

Ervas ou subarbustos, 0,3-1,5 m alt., glabriúsculos, esparsos tricomas simples, de base espessa e glandulares microscópicos. Caule ereto, glabriúsculo a glabro; entrenós 1-10 cm compr. Estípulas 0,8-2,5 × 0,5-1,2 cm, ovadas a obovadas, ápice apiculado, margem inteira a levemente ondulada, carenadas, apressas, persistentes. Folhas com pecíolo $(1,8-) 3-$ $10,5 \mathrm{~cm}$ compr., glabriúsculo; lâmina 10-25,5 × 5$12,8 \mathrm{~cm}$, inteira, assimétrica, basifixa, papirácea, elíptica a obovada, ápice acuminado, base cordada, margem irregularmente crenado-serrilhada, ciliada, glabrescente em ambas as faces; face adaxial verde, face abaxial verde-clara a vinácea; venação actinódroma, 6 ou 7 nervuras na base. Cimeiras 14-19 cm compr., 9-40 flores, 3-6 nós; brácteas de primeira ordem 2-5 $\times$ 1-2 mm, ovadas a lanceoladas, persistentes. Flores estaminadas sem bractéolas; tépalas 4, alvas a róseas, as externas maiores, ovadas, face abaxial com esparsos tricomas glandulares microscópicos a glabra, as internas elípticas a oblongas, face abaxial glabra; estames 15-32, anteras rimosas, conectivos proeminentes. Flores pistiladas com 2 bractéolas lanceoladas, persistentes; tépalas 5, alvas a róseas, três maiores, ovadas, face abaxial glabra; ovário com placenta inteira. Cápsulas 0,9-1,5 $\times 1,1-2,2 \mathrm{~cm}$, sem tricomas glandulares microscópicos, glabras; alas 3, desiguais, a maior 0,4-1,1 cm larg., ápice arredondado a obtuso, as menores 3-5 mm larg., arredondadas. Sementes oblongas.

Endêmica do estado da Bahia. G8, H8: Floresta ombrófila densa montana e submontana, e em restinga. Cresce sobre rochas ou em solos arenosos, sendo também encontrada no interior de plantações de cacau. Foi coletada com flores em fevereiro, maio e de julho a setembro, e com frutos em fevereiro, maio, agosto e setembro.

Material selecionado - Aurelino Leal, rodovia BR-101, trecho

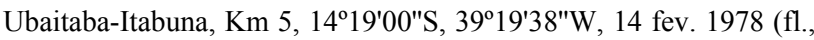
fr.), T.S. Santos et al. 3159 (CEPEC); Camamu, assentamento Oricó, 1356'S, 3906'W, 6 set. 2001 (fr.), M.L. Guedes et al. s.n. (ALCB 56120); Ilhéus, Castelo Novo, próximo à fazenda Almada, nas margens do rio Almada, 1447'20"S, 39 $02^{\prime} 58^{\prime \prime} \mathrm{W}, 7$ maio 2013 (bot., fl., fr.), B.S. Gregório 232 (HUEFS); ib. s.d. (fr.), C.F.P. Martius s.n. (holótipo de B. sylvatica: M 145742 [foto]); Santa Luzia, estrada de acesso à Serra da Onça, ca. $16 \mathrm{~km}$ a partir de Santa Luzia, 15²5'46"S, 39²0'03"W, 10 ago. 1999 (fl., fr.), A.M. Amorim et al. 3094 (CEPEC); Uruçuca, Reserva Gregório Bondar, área da EMARC, 143ㅇ' $08^{\prime \prime S}, 39^{\circ} 16^{\prime} 27^{\prime \prime} \mathrm{W}, 22$ set. 2000 (bot., fl.), $F$. Juchum et al. 48 (CEPEC).

Begonia sylvatica é facilmente reconhecida pelas lâminas foliares elípticas, com amplas dimensões (10$25,5 \times 5-12,8 \mathrm{~cm})$, glabriúsculas e com margem irregularmente crenado-serrilhada. Assemelha-se a $B$. angularis e a B. bahiensis, como comentado para aquelas espécies. 


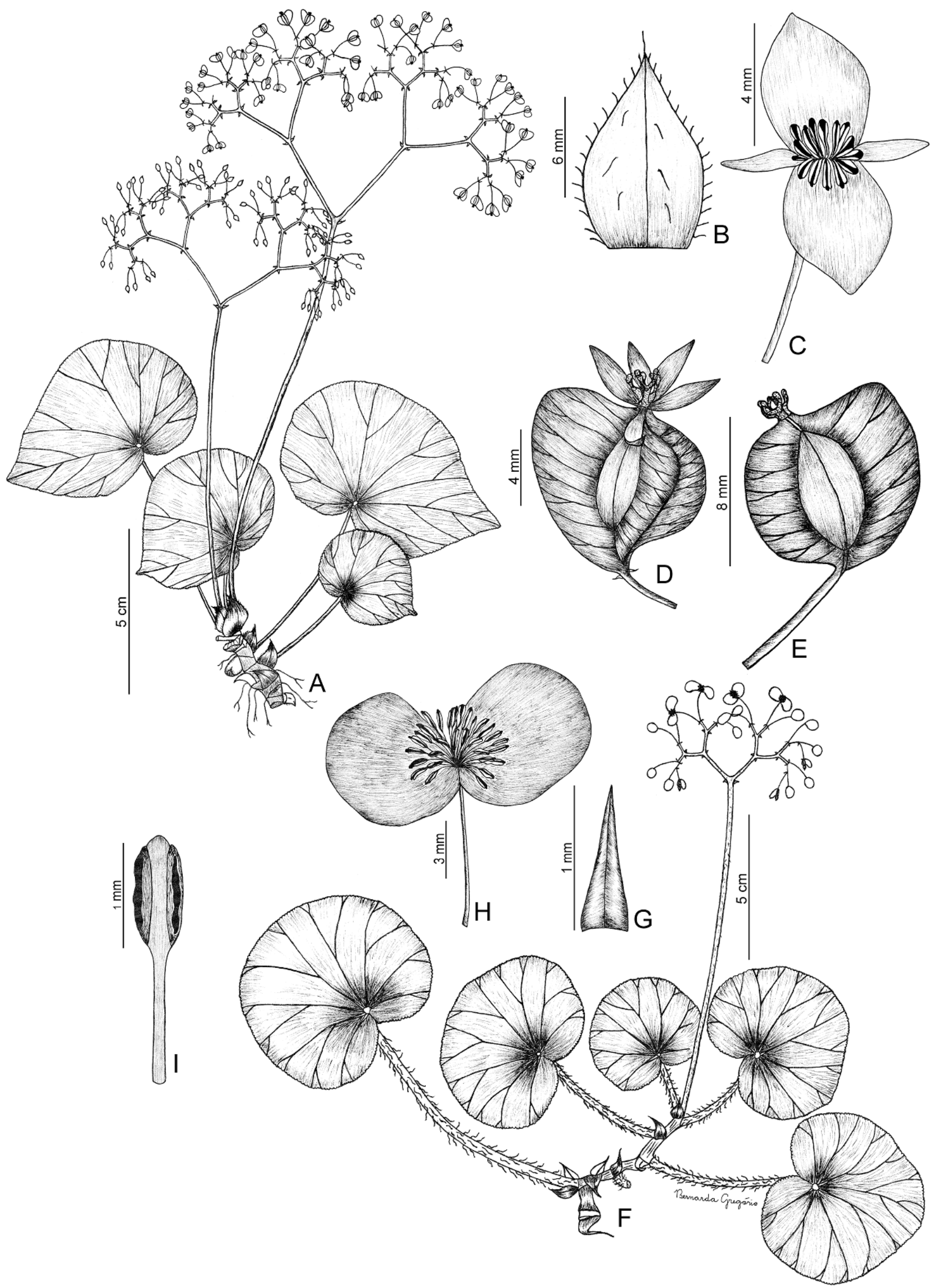

Figura 33. A-E. Begonia saxifraga: A- ramo florido; B- estípula; C- flor estaminada; D- flor pistilada; E- cápsula. F-I. $B$. subacida: F- ramo florido; G- bractéola de 1 $1^{\mathrm{a}}$ ordem; H- flor estaminada; I- estame. (A, B, E- Luschnath s.n. BR 517774; C- baseada em ilustração da Flora Brasiliensis [Candolle 1861, p. 97]; D- Borges 597; F-I- Pinheiro 2021). 


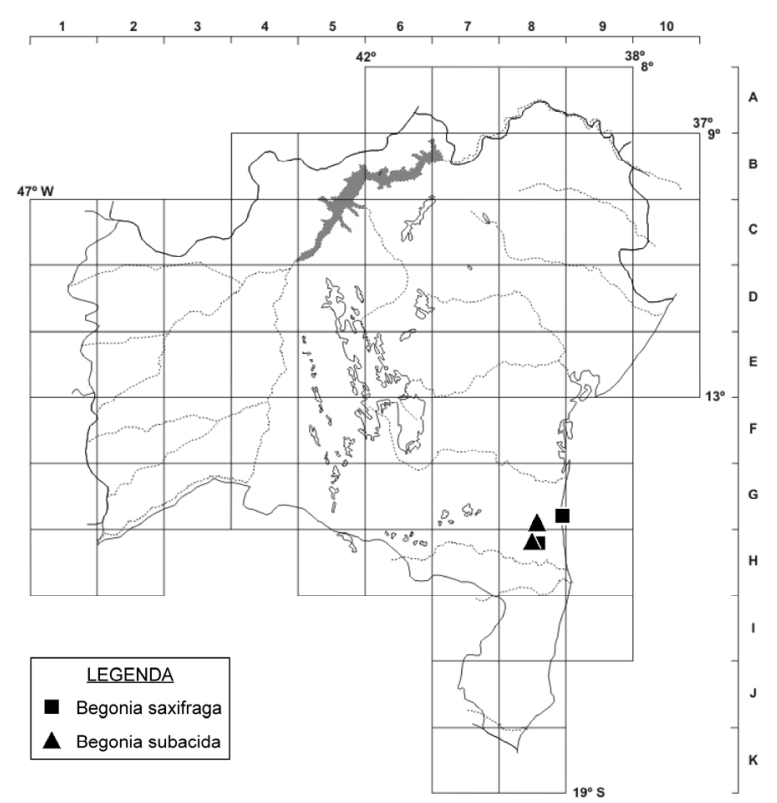

Figura 34. Mapa de distribuição de Begonia saxifraga e B. subacida no estado da Bahia.

37. Begonia ulmifolia Willd., Sp. Pl. 4(1): 418. 1805. Figuras 35G-L e 36.

Ervas ou subarbustos, 0,5-2 $\mathrm{m}$ alt., pilosos, tricomas simples e glandulares curtos. Caule ereto a escandente, glabrescente; entrenós 0,5-11(-17) $\mathrm{cm}$ compr. Estípulas $0,6-1,8 \mathrm{~cm} \times 2-4 \mathrm{~mm}$, estreitamente triangulares, ápice apiculado, margem inteira, apressas, carenadas, persistentes. Folhas com pecíolo $0,3-3 \mathrm{~cm}$ compr., piloso; lâmina 5-12 × 1-6 cm, inteira, assimétrica, basifixa, papirácea, elíptica a obovada, ápice agudo a acuminado, base oblíqua, margem irregularmente serrilhada a serreada, ciliada, pilosa em ambas as faces, mais densamente na face abaxial; face adaxial verde, face abaxial verde-clara a vinácea; venação craspedódroma. Cimeiras (3,5-)6,5-15 cm compr., 10-50 flores, 3-5 nós; brácteas 0,3-1,5 cm $\times$ 1-4 mm, estreitamente triangulares, persistentes. Flores estaminadas sem bractéolas; tépalas 2, 0,5-1,2 $\mathrm{cm} \times 4,5-9 \mathrm{~mm}$, ovadas a orbiculares, face abaxial pilosa, com tricomas glandulares microscópicos; estames 26-74, anteras rimosas, conectivos proeminentes. Flores pistiladas com 2 bractéolas estreitamente triangulares, persistentes; tépalas 5, alvas, três maiores, elípticas a ovadas, face abaxial pilosa, com tricomas glandulares microscópicos; ovário com placenta partida. Cápsulas $0,5-1,3 \times 0,9$ 2,7 cm, pilosas, com tricomas glandulares microscópicos; alas 3, desiguais, a maior $0,5-1,8 \mathrm{~cm}$ larg., ápice arredondado a agudo, as menores 1-3 $\mathrm{mm}$ larg., arredondadas. Sementes oblongas.

Esta espécie ocorre no Brasil, Guiana, Guiana Francesa, Suriname e Venezuela (Kollmann 2012). No Brasil, é encontrada nos estados de Alagoas, Bahia, Espírito Santo, Minas Gerais, Paraíba, Pernambuco, Rio de Janeiro e Sergipe (Jacques 2015). A8, D7, E7, E8, E9, G7, H8, H9, J8: Floresta ombrófila densa montana e submontana, floresta estacional semidecidual, floresta estacional semidecidual submontana, mata de cipó, mata ciliar, capoeira e caatinga. Ocorre em solos arenosos ou entre rochas, em áreas com acúmulo de matéria orgânica, além de margens de córregos, encostas ou sub-bosques; é encontrada exposta ao sol, mas geralmente recebe proteção da vegetação mais alta circundante. Floresce e frutifica de abril a novembro.

Material selecionado - Boa Nova, 3,3 km à leste de Boa Nova, na estrada para Dário Meira, $14^{\circ} 22^{\prime} \mathrm{S}, 40^{\circ} 11^{\prime} \mathrm{W}, 850-900 \mathrm{~m}$ s.n.m., 15 out. 2000 (fl.), W.W. Thomas et al. 12274 (CEPEC, MBML, NY); Cachoeira, $12^{\circ} 32^{\prime} \mathrm{S}, 39^{\circ} 05^{\prime} \mathrm{W}, 40-120 \mathrm{~m}$ s.n.m., ago. 1980 (f1.), Grupo Pedra do Cavalo 585 (ALCB, BAH, CEPEC, HRB, HUEFS, RB); Canavieiras, Santa Maria Eterna, estrada a Canavieiras, $15^{\circ} 40^{\prime} 30^{\prime \prime} \mathrm{S}, 38^{\circ} 56^{\prime} 50^{\prime \prime} \mathrm{W}, 23$ set. 1970 (fl., fr.), T.S. Santos 1149 (CEPEC); Conceição do Almeida, fazenda Santa Cruz, à margem do rio, 12\%48'32"S, 3909'50"W, 6 set. 1959 (fl.), A.L. Costa 545 (ALCB); Feira de Santana, fazenda Chapada, $12^{\circ} 16^{\prime} \mathrm{S}, 38^{\circ} 58^{\prime} \mathrm{W}, 13$ out. 2011 (fl., fr.), E. Melo et al. 10449 (HUEFS); Ipirá, fazenda Recreio, Estrada do feijão, Km 43, $12^{\circ} 22^{\prime} \mathrm{S}, 38^{\circ} 41^{\prime} \mathrm{W}, 4$ out. 1986 (fl.), L.P. Queiroz et al. 982 (CEPEC, HUEFS); Itaberaba, fazenda Gameleira, entrando entre a fazenda Monte Verde e a fazenda Leão dos Brejões, $12^{\circ} 24^{\prime} 44^{\prime \prime} \mathrm{S}$, 40³2'12"W, 783 m s.n.m., 19 ago. 2005 (fl.), L.P. Queiroz et al. 10787 (CEPEC, HUEFS) Jacobina, Itaitu, fazenda Timbó, $11^{\circ} 15^{\prime} 57^{\prime \prime S}, 40^{\circ} 28^{\prime} 00^{\prime W}, 620$ m s.n.m., 6 set. 1999 (fl.), E. Melo et al. 2999 (HUEFS, SPF); Morro do Chapéu, cachoeira Domingos

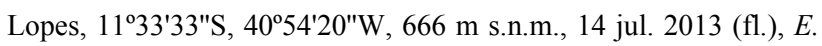
Melo et al. 12078 (HUEFS); Ruy Barbosa, Serra do Orobó, Boca do Leão, 12²8'11"S, 40³1'13"W, 425 m s.n.m., 28 jul. 2004 (fl.), L.P. Queiroz et al. 9403 (HUEFS); Teixeira de Freitas, vale do rio Alcobaça, 17³2'06"S, 3944'31"W, 15 ago. 1972 (fl., fr.), T.S. Santos 2378 (CEPEC).

Material adicional - VENEZUELA. CARACAS: La venta: s.d. (fl., fr.), A. Humboldt 690 (holótipo de B. ulmifolia: B [foto]).

Begonia ulmifolia caracteriza-se pelo indumento piloso em toda a planta, pelo caule verde com nuances vináceas in vivo e marrom in sicco, estriado e anguloso, pelas estípulas estreitamente triangulares e pelas flores estaminadas com duas tépalas. Assemelhase a $B$. saxicola pelas características mencionadas naquela espécie.

38. Begonia umbraculifera Hook. f., Bot. Mag. 22: tab. 7457. 1896.

Figuras 35M-Q e 36.

Subarbustos, 0,4-1,5 m alt., glabriúsculos a glabros, esparsos tricomas simples, estrelados e glandulares microscópicos. Caule ereto, glabriúsculo a glabro; entrenós 0,7-3,8 cm compr. Estípulas 1-4× 0,7-2,3 cm, triangulares, ápice apiculado, margem inteira, apressas, caducas. Folhas com pecíolo 2,3-5,2 cm compr., glabro ou com esparsos tricomas glandulares; lâmina 4,6-14 × 4,6-13,2 cm, inteira, simétrica a levemente assimétrica, peltada, crassa, orbicular, ápice arredondado, margem denticulada a levemente ondulada, glabrescente a glabra em ambas as faces; face adaxial verde, face abaxial verde-clara; 


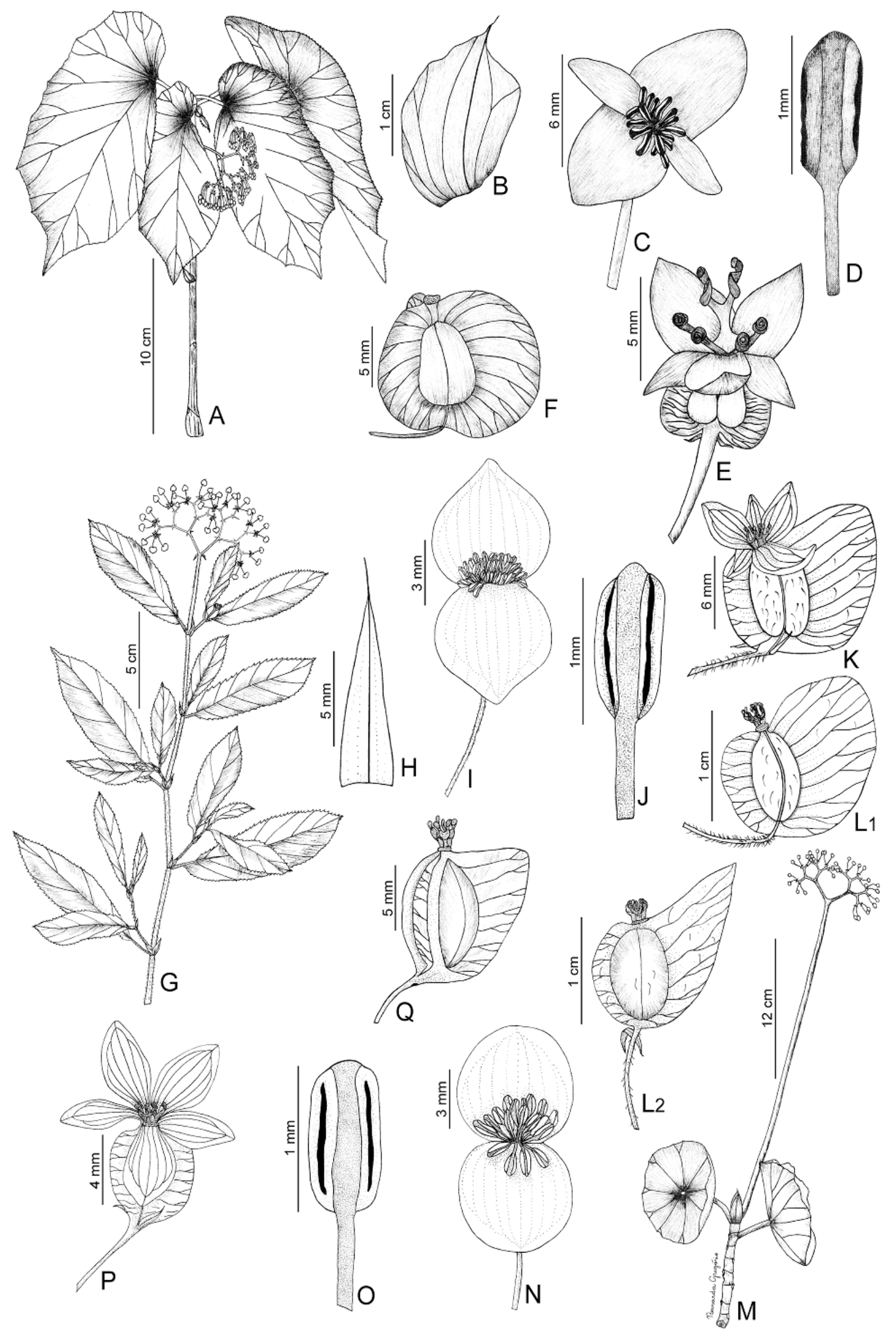

Figura 35. A-F. Begonia sylvatica: A- ramo florido; B- estípula; C- flor estaminada; D- estame; E-flor pistilada; F- cápsula. G-L- B. ulmifolia: G- ramo florido; H- estípula; I- flor estaminada; J- estame; K- flor pistilada; L1, 2- cápsula. M-Q- B. umbraculifera: M- ramo florido; N- flor estaminada; O- estame; P- flor pistilada; Q- cápsula. (A-F- Gregório 232; G-J- Queiroz 10787; K, L1- Noblick 4390; L2- Pinto 140; M-O- Stradmann 669; P, Q- Gregório 197). 


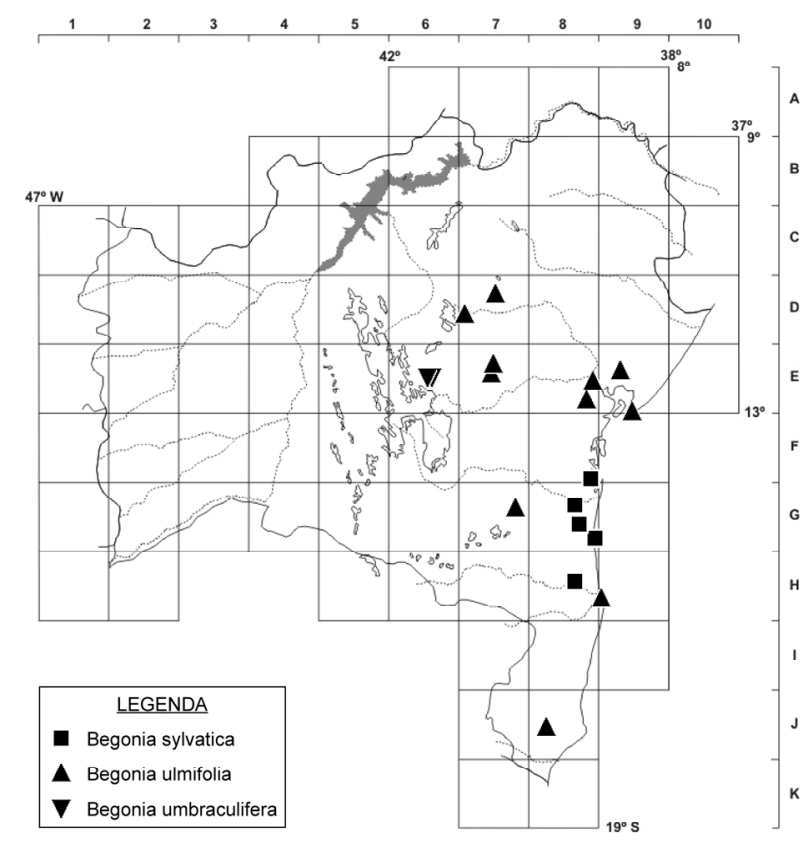

Figura 36. Mapa de distribuição de Begonia sylvatica, B. ulmifolia e B. umbraculifera no estado da Bahia.

venação actinódroma, 6-9(-11) nervuras a partir do ápice do pecíolo. Cimeiras $18-61,8 \mathrm{~cm}$ compr., 16-80 flores, 4-6 nós; brácteas de primeira ordem caducas [não vistas]. Flores estaminadas sem bractéolas; tépalas 2(4), alvas, orbiculares a ovadas, face abaxial glabrescente a glabra; estames 18-28, anteras rimosas, conectivos proeminentes. Flores pistiladas com 2 bractéolas estreitamente elípticas, caducas; 5 tépalas, róseas, duas ligeiramente maiores, elípticas a ovadas, face abaxial glabra; ovário com placenta inteira. Cápsulas $1-1,3 \times 1,1-1,8 \mathrm{~cm}$, com esparsos tricomas glandulares microscópicos; alas 3, desiguais, a maior 3 $7,5 \mathrm{~mm}$ larg., ápice arredondado a agudo, as menores 2 4,5 mm larg., arredondadas. Sementes oblongas.

Endêmica da Bahia (Jacques 2015), é conhecida somente de Lençóis e Palmeiras. E6: Cerrado, campo sujo e, principalmente, campo rupestre. Cresce em vales de rios, afloramentos rochosos de arenito, sobre ou entre rochas, com solos arenosos, pedregosos, litólicos ou hidromórficos. Floresce e frutifica praticamente o ano todo.

Material selecionado - 1893 (fl.), F. Sander et al. 105 (holótipo de B. umbraculifera: $\mathrm{K}$ [foto]); Lençóis, área ao $\mathrm{S}$ da rodovia BR-324, no vale do rio Mucugezinho, $12^{\circ} 27^{\prime} 48^{\prime \prime} \mathrm{S}$, 4125'06"W, 786 m s.n.m., 18 set. 2002 (fl.), L.P. Queiroz et al. 7432 (HST, HUEFS); Palmeiras, beira da BR-242, próximo ao rio Mucugezinho, $12^{\circ} 28^{\prime} \mathrm{S}, 41^{\circ} 23^{\prime} \mathrm{W}, 11$ jan. 2012 (fl., fr.), B.S. Gregório et al. 197 (HUEFS).

Begonia umbraculifera caracteriza-se pelo indumento glabriúsculo a glabro, estípulas caducas e lâminas foliares orbiculares, peltadas e simétricas a levemente assimétricas. Foram encontradas flores estaminadas com quatro tépalas em alguns espécimes (Guedes PCD 365 e Ramos 1146), uma característica rara na espécie.
Begonia umbraculifera foi descrita por Hooker (1896) a partir de uma planta importada do Brasil por F. Sander, conhecido vendedor de orquídeas da época, e cultivada no Royal Botanic Gardens de Kew (Reino Unido). Devido às semelhanças morfológicas, $B$. umbraculifera vinha sendo erroneamente identificada como B. fellereriana. Contribuía para isso o fato de que, no protólogo, a localidade-tipo foi citada como incerta e, assim, não se tinha conhecimento de que as duas espécies não ocorrem na mesma região.

\section{AgradeCimentos}

Este estudo é parte da dissertação de mestrado de BSG, desenvolvida no PPGBot-UEFS, com bolsa do CNPq (PROTAX 562278/2010-9). Agradecemos ao CNPq pelo apoio ao projeto Flora da Bahia (483909/2012-4), à Eliane Jacques pela assistência e discussões sobre Begonia, às Dras Ana Maria Giulietti e Efigênia de Melo pelas correções e sugestões e a dois pareceristas anônimos pelas valiosas contribuições no manuscrito. AR é bolsista PQ-1D do CNPq.

\section{REFERÊNCIAS}

Aublet, J.B.C.F. 1775. Begonia glabra. In: P.-F. Didot (ed.), Histoire des Plantes de la Guiane Françoise. Vol. 2. Libraire de la Faculté de Médecine Quai des Auguftins, London, p. 916917, t. 349.

Brade, A.C. 1954. Begônias novas do Brasil, VII. Arquivos do Jardim Botânico do Rio de Janeiro 13(1): 82-84.

Brade A.C. 1971. Uma espécie nova do gênero Begonia, do estado da Bahia, Brasil, e sinopse das espécies brasileiras publicadas nos anos de 1944 a 1958. Boletim do Herbarium Bradeanum 1(6): $37-38$.

Candolle, A.P. 1859. Mémoire sur la famille des Begoniacées. Annales des Sciences Naturelles Botanique, sér. 4, 11: 93-149.

Candolle, A.P. 1861. Begoniaceae. In: C.P.F. Martius (ed.), Flora Brasiliensis. Vol. 4, part. 1. Frid. Fleischer, Monachii, p. 338396.

Clement, W.L.; Tebbit, M.C.; Forrest, L.L.; Blair, J.E.; Brouillet, L.; Eriksson, T. \& Swensen, S.M. 2004. Phylogenetic position and biogeography of Hillebrandia sandwicensis (Begoniaceae): a rare Hawaiian relict. American Journal of Botany 91(6): 905-917.

Duarte, A.P. 1961 ("1959-1961"). Considerações acerca do comportamento e dispersão de algumas espécies de Begônias do estado da Guanabara. Arquivos do Jardim Botânico do Rio de Janeiro 17(1): 57-105.

Feliciano, C.D. 2009. Flora de Minas Gerais - Begoniaceae. Dissertação de mestrado. Universidade de São Paulo.

Goodall-Copestake, W.P.; Harris, D.J. \& Hollingsworth, P.M. 2009. The origin of a mega-diverse genus: dating Begonia (Begoniaceae) using alternative datasets, calibrations and relaxed clock methods. Botanical Journal of the Linnean Society 159(1): 363-380. 
Gregório, B.S.; Jacques, E.L.; Costa, J.A.S \& Rapini, A. 2014. Begonia obdeltata (Begoniaceae), a new species from northeast Brazil. Phytotaxa 167(2): 189-194.

Gregório, B.S.; Costa, J.A.S \& Rapini, A. 2015. Three new species of Begonia (Begoniaceae) from Bahia, Brazil Phytokeys 44: 1-13.

Hooker, J.D. 1896. Begonia umbraculifera. Curtis's Botanical Magazine 122(3): 841-843.

Irmscher, E. 1953. Systematische Studien über Begoniaceen des Tropischen Südamerikas Besonders Brasiliens. Botanische Jahrbücher für Systematik 76(1): 1-102.

Jacques, E.L. 2002. Estudos Taxonômicos das Espécies Brasileiras do Gênero Begonia L. (Begoniaceae) com Placenta Partida. Tese de doutorado. Universidade de São Paulo.

Jacques, E.L. 2009. Begoniaceae. In: A.M. Giulietti, A. Rapini, M.J.G. Andrade, L.P. Queiroz \& J.M.C. Silva (eds), Plantas Raras do Brasil. Conservação Internacional, Belo Horizonte, p. 91-94.

Jacques, E.L. 2015. Begoniaceae. In: Lista de Espécies da Flora do Brasil. Jardim Botânico do Rio de Janeiro. Disponível em http://reflora.jbrj.gov.br/jabot/floradobrasil/FB59; acesso: 17 março 2015.

Jacques, E.L. \& Mamede, M.C.H. 2004. Novelties in Begonia (Begoniaceae) from the coastal forests of Brazil. Brittonia 56(1): 75-81.

Jacques, E.L. \& Mamede, M.C.H. 2005. Notas nomenclaturais em Begonia L. (Begoniaceae). Revista Brasileira de Botânica 28(3): 579-588.

Kollmann, L.J.C. 2012. Diversidade, Biogeografia e Conservação das Begoniaceae do Estado do Espírito Santo, Brasil. Dissertação de mestrado. Universidade Federal do Espírito Santo.

Kollmann, L.J.C. \& Fontana, A.P. 2010. Begonia goldingiana L. Kollmann \& A. P. Fontana (Begoniaceae), a new species from the Atlantic Forest of Southern Bahia, Brazil. Candollea 65(2): $185-188$.

Mamede, M.C.H.; Silva, S.J.G.; Jacques, E.L. \& Arenque, B.C. 2012. Begoniaceae. In: M.G.L. Wanderley, G.J. Shepherd,
T.S.A. Melhem, A.M. Giulietti, S.E. Martins, J.R. Pirani, M. Kirizawa, M.M.R.F. Melo, I. Cordeiro \& L.S. Kinoshita (eds), Flora Fanerogâmica do Estado de São Paulo. Vol. 7. Instituto de Botânica, São Paulo, p. 73-115.

Neale, S.; Goodall-Copespeak, W. \& Kidner C. 2006. The evolution of diversity in Begonia. In: J.A. Teixeira da Silva (ed.), Floriculture, Ornamental and Plant Biotechnology: advances and topical issues. Global Science Books, London, p. 606-611.

Pandikumar, P.; Prakash Babu, N. \& Ignacimuthu, S. 2009. Hypoglycemic and antihyperglycemic effect of Begonia malabarica Lam. in normal and streptozotocin induced diabetic rats. Journal of Ethnopharmacology 124(1): 111-115.

Ramesh, N.; Viswanathan, M.B.; Saraswathy, A.; Balakrishna, K.; Brindha, P. \& Lakshmanaperumalsamy, P. 2002. Phytochemical and antibacterial studies of Begonia malabarica. Journal of Ethnopharmacology 79(1): 129-132.

Smith, L.B. \& Smith, R.C. 1971. Begoniáceas. In: P.R. Reitz (ed.), Flora Ilustrada Catarinense. Herbário Barbosa Rodrigues, Itajaí, p. 1-128.

Smith, S.F. \& Wasshausen, D.C. 1999. New taxa in Begonia (Begoniceae) from Brazil. Selbyana 20(1): 16-29.

Smith, L.B.; Wasshausen, D.C.; Golding, J. \& Karegeannes, C.E. 1986. Begoniaceae: Part. I: Illustrated Key. Part II: Annotated Species List. Smithsonian Contributions to Botany 60: $1-584$.

Sosef, M.S.M. 1994. Refuge Begonias: Taxonomy, phylogeny and historical biogeography of Begonia sect. Loasibegonia and sect. Scutobegonia in relation to glacial rain forest refuges in Africa. $\mathrm{PhD}$ thesis. Wageningen Agricultural University.

Souza, V.C. \& Lorenzi, H. 2008. Botânica Sistemática: guia ilustrado para identificação das famílias de Fanerógamas nativas e exóticas no Brasil, baseado em APG II. 2 ed. Instituto Plantarum, Nova Odessa.

Wu, P.L.; Lin, F.W.; Wu, T.S; Kuoh, C.S; Lee, K.H. \& Lee, S.J. 2004. Cytotoxic and anti-HIV principles from the rhizomes of Begonia nantoensis. Chemical and Pharmaceutical Bulletin 52(3): 345-349.

\section{LISTA DE EXSICATAS}

Allem, A. 1768 (16); Almeida, E.F. 25 (25); Almeida-Silva, G. 306 (16); Alves, L.J. 280 (4), s.n. ALCB 87037 (22), s.n. ALCB 88095 (12); Alves, M. 1328 (16), 1995 (14); Amorim, A.M. 328 (2), 621, 623 (14), 1679, 1690 (18), 1692 (28), 1867 (2), 1905,1940 (14), 1942 (36), 2309 (2), 2370 (35), 2436 (18), 2447 (26), 2460 (4), 2473 (3), 2813 (16), 3063 (4), 3094 (36), 3425, 3595 (14), 3603 (29), 3650 (18), 3866 (16), 4081 (7), 4165 (4), 4176 (18), 4217 (23), 4229 (13), 4348 (28), 4387 (21), 4527 (14), 4760 (18), 4760 a (21), 4906 (16), 4912 (4), 4971 (13), 5005 (18), 5067 (31), 5144 (4), 5265 (13), 5274, 5275 (28), 5280, 5370 (4), 5382 (18), 5388 (23), 5453 (12), 5698,5953 (21), 5974 (18), 6259 (31), 6290 (23), 6322 (13), 6522 (18), 6587 (28), 6654 (18), 6901 (15), 6913 (29), 7033 (14), 7057 (16), 7306 (18); Andrade, M. 131 (16), s.n. ALCB 2895 (29); Andrade, M.J.G. 109 (16); Aona, L.Y.S. 1595, 1886, 2345 (16), 2997,2998 , 3201 (29), 3314, 3409 (14), 5106 (1); Arbo, M.M. 5440 (25), 7407 (16); Assis, J.S. 425 (16); Azevedo, C. 105 (23), 461 (3); Barros, F. 1792 (4); Bastos, B.C. 165 (29); Bautista, H.P. 62, 916, 1257, 1387 (16), 1998 (38), 1999 (4), 2535 (16), 2931 (30), 2961 (37), 3030 (29), 3437, 3608, 4217, 4225 (16); Belém, R.P. 1002 (21), 1240, 1250 (12), 1763 (4), 2629 (27), 2733 (4); Bispo, R.B. 6 (14); Bonfin, E.S. 2 (2); Borba, E.L. 1956 (29), 1957 (16), 2059 (25); Borges, R.A.X. 415 (16), 416 (21), 452 (7), 557 (21), 570 (14), 597 (33), 602 (4); Brazão, J.E.M. 50 (16); Brito, H.S. 38 (12); Burle Marxi, R. 43240 (22); Callejas, R. 1541 (2), 1568 (27), 1600 (4); Cano, O. 885 (17); Cardoso, D. 247 (29), 427 (16), 659 (25), 754 (29), 758 (25), 1305 (32), 1403 (29), 1409 (32), 1713 (18), 2143 (12); Carneiro-Torres, D.S. 39 (25), 519 (32); Carvalho, A.M.V. 283 (2), 304 (36), 982 (16), 2019 a (2), 3657 (14), 4165 (16), 4610 (14), 6698 (3), 6704 (26), 6819 (2), 6836 (26), 6840, 6858 (2), 7008 (21), 7021 (16); Carvalho, D.N. 104 (29); Carvalho, G. 100 (25); Carvalho-Sobrinho, J.G. 146 (32); Cavalcanti, D. 421 (30); Coelho, M.M. 384, 410, 452 (18), 604 (7), 617, 629 (14); Conceição, A.A. 205 (16), 1264 (30), 4066 (16); Conceição, A.S. 421 (16), 905 (12); Conceição, S.F. 33 (29); Coradin, L. 6189, 6507 (16); Correia, C. 114 (30), 116 (25); Costa, A.L. 545 
(37), 618 (16), s.n. ALCB 2891 (37), s.n. ALCB 2894 (16), s.n. ALCB 2896 (29); Costa, J.A.S. 33, 1593 (17), 1594 (37), 1799 (16), 1835 (38); Couto, A.P.L. 46 (29); Curran, H.M. 200 (22); Davidse, G. 11915 (25); Duarte, A.P. 9176 (16), 10622, 14094 (30); Dupasquier, L. s.n. G-DC 457528 (22); Eggli, U. 1192 (29), 1205, 1224 (16); Espinosa, D.R. 916 (5); Espírito-Santo, F.S. 181 (16); Eupunino, A. 284 (17), 362 (29); Farias, E. 25 (25); Ferraz, J. 127 (17); Ferreira, F.M. 1298 (4), 1830 (1); Ferreira, J.D.C.A. 107 (25); Ferreira, J.L. 156 (16); Ferreira, M.C. 1080 (30), 1102 (12), 1834 (38); Ferreira-Silva, A. 2 (16); Fiaschi, P. 1063 (2), 1129 (4), 1131 (28), 1150 (18), 1203 (2), 1276, 1479 (4), 1533 (18), 1565 (7), 1592 (18), 1704 (8), 1804 (14), 1806 (13), 1807 (7), 1837 (18), 1902 (14), 2154 (31), 2398 (16), 2937 (13); Florêncio, C.S. 33 (36); Fontana, A.P. 2499 (22), 2500 (2), 2543 (17), 2605 (18), 2608 (14), 2614 (16), 2615 (7), 4145 (15), 6345 (16), 6712 (25), 7262 (11); Forzza, R.C. 1175, 1264 (16), 1385 (29); Foster, M.B. 2463 (16); França, F. 1843 (32), 2023 (12), 2342 (29), 2661 (25), 3049 (16), 3140 (29), 3851 (17), 4770 (32), 5216 (16), 5219 (25), 5369 (16); Freire-Fierro, A. 1659 (16); Freitas, J.G. 785 (16); Furlan, A. 257 (30), 284, 285 (25), 1967, 2129 (16); Ganev, W. 687 (29), 1030 (16), 3048, 3134 (30); Gardn. G. 2029 (32); Giulietti, A.M. 1432 (16), 1865 (11), 3303 (29), 3495 (4), 53845 (16); Gomes, D.F. 5 (16), Gomes, F.S. 595, 953 (16), 1159 (12); Gregório, B.S. 121 (16), 193 (32), 194 (12), 195, 196 (16), 197 (38), 198 (13), 199 (7), 200 (14), 201 (18), 202 (16), 203 (18), 204 (14), 205 (18), 206 (21), 207 (23), 208 (13), 209 (4), 210 (25), 211 (30), 212 (25), 213 (29), 214 (16), 215 (18), 216, 217 (4), 218 (28), 219,220 (18), 221 (4), 222 (13), 223, 224 (4), 225 (21), 226 (28), 227, 228 (18), 229 (5), 230 (23), 231 (2), 232 (36), 233 (21), 234 (9), 237 (22), 238 (17), 239 (2), 240 (29), 241 (15), 243 (29), 244 (12), 247, 248 (31), 249 (18), 250 (4), 251 (13), 252 (14), 253 (1), 254 (29), 257 (19), 260 (18), 261 (4); Grupo Pedra do Cavalo 467 (29), 585, 752 (37), 984 (12); Guedes, M.L.S. 365 (38), 624 (16), 748 (38), 1400, 1430 (16), 1980 (30), 2100 (16), 4854 (17), 5087 (37), 6309 (17), 6955, 9380 (16), 9868 (30), 10776 (25), 11297, 11319, 11348, 12536 (16), 12909 (29), 12959 (25), 13893 (30), 13939 (25), 14556 (30), 14562 (29), 14564 (17), 14804 (37), 15069 (16), 16315 (22), 16814 (16), 17206 (37), 17226, 17382 (29), 17761 (16), 19288 (30), 19289 (25), s.n. ALCB 56120 (36), s.n. ALCB 67180 (16); Hage, J.L. 362 (22), 587, 954, 1055, 1086, 1269 (2), 1311 (27), 1312 (21), 1334, 1340, 2031 (2); Harley, R.M. 3116 (29), 3778 (4), 4485 (30), 7216 (30), 14043, 15405 (16), 16566, 16959 (25), 17238 (17), 18709 (16); 19472 (2), 19525 (16), 20096 (30), 20682 (2), 21020, 22383 (16), 22762, 22836 (25), 22921 (30), 24631,25323 (12), 25796, 26122, 26422 (16), 27827 (30), 28234, 28327 (16), 50355 (30), 50500 (29), 50523 (30), 54081 (32); Hatschbach, G. 39615 (30), 39681 (25); Heringer, A. 2412 (30); Hind, D.J.N. 3970 (16); Irwin, H.S. 32468 (25), Jacques, E.L. 736, 737 (16), 802 (3); 803 (27), 804 (26); Jardim, A.B. 114 (28); Jardim, J.G. 443 (14), 725 (25), 831 (18), 1130, 1135, 1141 (14), 1496 (2), 1497, 1733 (26), 1734,1752 (2), 1834 (18), 2984 (14), 3052 (4), 4014 (29), 4386 (21), 4388 (18), 4660 (14), 4999 (31), 5014 (31), 5031 (16); Juchum, F. 48 (36); Junqueira, M.E.R. 95, 136 (16); Kallunki, J. A. 437 (2); Kameyama, C. 8915 (16); King, R.M. 8765 (16); Kollmann, L. 11561 (17), 11570 (12), 11571 (15), 12104 (2), 12107 (29), 12110 (15), 12121 (12), 12126 (2), 12204 (17); Kral, R. 75625,75639 (16); Kuhlmann, E. 2 (25); Leite, J.E. 3282 (17); Leite, K.R.B. 424 (38); Leitman, P. 102 (28), 142, 143, 168 (4), 206 (28), 338 (18), 352 , 365 (28), 382 (13), 383 (4), 384 (13), 390 (28), 424, 501 (23), 545 (4); Lewis, G.P. 706 (12), 753 (2), 756 (15), 768 (4), 769 (29), 896 (16), 906,945 (38), 7023 (16); Liuth, H.S. 98 (13); Lôbo, C.M.B. 59 (16); Lombardi, J.A. 8893 (17); Lopes, M.M.M. 309 (13), 322 , 331 (14), 347 (7), 383 (18), 392 (14), 420 (18), 603 (28), 604 (21), 753 (4), 756, 989 (13), 1295 (4), 1478 (13), 1525 (18); Lordelo, R.P. 474 (12); Lorenzi, H. 6946 (2), 6952 (15), 7114 (16); Loureiro, D.M. 424, 754 (14), s.n. ALCB 60330 (16); Lourteig, A. 3236 (18); Luceño, M. 310 (16); Luschnath, B. s.n. BR 517774 (33); Lyra-Lemos, R.P. 1849 (16); Maas, P.J.M. 6980 (9); Machado, A.F.P. 995 (16); Magalhães, C.M. 79 (2); Magalhães, G.M. 19561 (14); Marinho, L.C. 433 (18), 675 (15); Martinelli, G. 5212 (16), 5217 (25), 5323,5434 (16), 14831 (15); Martius, C.F.P. 928 (27), 954 (33), 955 (21), 2303, 2803 (11), s.n. M 113294 (2), s.n. NY 118649 (35), s.n. M 145673, s.n. M 145674 (9), s.n. M 145736 (33), s.n. M. 145739, s.n. M 145740 (35), s.n. M 145742, s.n. M 145743, s.n. NY 454077 (36); Mattos Silva, L.A. 660 (20), 662 (2), 681 (29), 1626 (16), 2003 (2), 2016 (12), 2797 (16), 4448 (31), 4461 (18), 4463 (31), 4469 (14), 4489 (1), 4911 (18); Mayo, S. 818 (18); Melo, E. 1044 (12), 1173, 1206, 1260 (16), 1813 (12), 1834, 1877 (29), 1882 (32), 2009 (12), 2210 (29), 2999 (37), 3128 (25), 3458 (30), 4204 (12), 5211 (25), 6004, 6059 (29), 8508 (25), 9068 (14), 9652 (30), 9673 (16), 10449, 12078 (37); Melo, P.A. 107 (29); Melo Filho, L.E. 2399 (2), 2916 (18); Mello Silva, R. 7218 (16); Menezes, C.M. 91 (16); Milliken, W. 5106 (1); Miranda, A.M. 4309 (16); Miranda, E.B. 110 (16); Monteiro, R.F. 534 (31); Moraes, A. 10 (16); Mori, S.A. 10071 (2), 10566 (17), 10684 (4), 10699 (15), 12323 (12), 12376 (16), 12823 (28), 12856 (14), 13614 (16); Nascimento, J.G. 312 (16); Nascimento, J.O.V. 31 (29), 39 (12); Neves, S.P.S. 137 (38); Nic Lughadha, E. 50556 (29); Noblick, L.R. 1438 (16), 1975, 2005 (29), 2017 (32), 2731 (12), 2816 (16), 2835 (38), 2881 (16), 4390 , (37), 4392 (29); Nonato, F.R. 839, 1000 (16); Novais, J.S. 37 (16); Nunes, T.S. 191 (38), 360 (16), 1187 (25); Ogasawara, H.A. 172 , 263 (16), 273 (18), 280 (16); Oliveira, E. 116 (16); Oliveira, R.P. 236 (25), 738, 740 (26), 740 a (2); Orlandi, R.P. 200 (37), 759 (16); Pacheco, L.M. s.n. ALCB 29197, 63 (17); Paixão, J.L. 11 (4), 92 (2), 872 (16), 1337 (29), 1509 (4); Passos, L.A. 213 (38); Paula, L.F.A. 22 (16); Paula-Souza, J. 4861 (16); Perdiz, R.O. 45, 46, 47 (18), 214 (29), 290 (9), 412, 904 (18); Pereira, E. 1990 (29), 1991 (37), 2008 (25), 2178 (38), 10086 (16); Pessoa, E. 621 (2); Pigozzo, C.M. 50 (16); Pinheiro, R.S. 129, 456 (18), 1088 (16), 1224 (14), 1898 (26), 1905 (27), 1906 (29), 1930 (8), 2021 (35); Pinto, G.C.P. 4 (17), 8 (2), 39 (12), 48 (18), $53-55$ (6), 65 (29), 109 (17), 140 (37), 151 (12), 391 (25), 587 (6), s.n. ALCB 2890 (37); Pirani, J.R. 7504 (16); Pires, F.R.S. 2243 (30); Prata, A.P. 948 (38); Profice, S.R. 114 (14); Queiroz, L.C. 2 (29); Queiroz, L.P. 582 (16), 781 (17), 969 (29), 982 (37), 1178 (16), 1259 (30), 1836 (16), 1944 (30), 2409 (16), 4581 (32), 5151,5152 , 5167 (16), 6364 (23), 7432 (38), 9334, 9379 (25), 9403 (37), 9768 (25), 9925 (29), 10751 (25), 10787 (37), 10790 (24), 12827 (17), 13144 , 13159 (29), 14869 (16), 15548 (16); Ramos, A.E. 1146 (38), 1187 (16); Ramos, C.E. 33 (22), 186 (4), 293 (22), 552 (29), 554 (22); Rando, J.G. 1112 (38); Ribeiro-Filho, A.A. 78 (16), 199 (14); Riedel, L. 138 (2), 586 (21), 588 (9), 592 (33), 671 (14), s.n. G-DC 7335 (21); Rocha, L. 404 (16); Roque, N. 893, 1019 (16), 1210 (25), 1592, 1704 (16), 1848 (30), 2027 (16), 3406 (37), 3431, s.n. ALCB 61414, s.n. ALCB 64775 (16); Russell, G.F. s.n. US 324375, s.n. US 324414 (31); Salgado, O.A. 356 (30); Salimena-Pires, F.R. 2243 (30); Salino, A. 9126 (29), 9127 (32), 9134 (22), 9158 (3); Sander, F. 105 (38); Sano, P.T. 14651 (30), H 52338 (16); Sant'ana, S.C. 23 (29), 614 (14); Santana, D.L. 526 (4), 534 (36); Santos, F.S. 68 (4), 417 (29), 518 (17); Santos, T.R. 5640 (16); Santos, T.S. 518 (17), 774 (37), 1146 (29), 1149 (37), 1160 (31), 1325 (22), 1734 (31), 1813 (37), 1842 (22), 1874 (4), 1989 (29), 2378 (37), 2400 (12), 3104 (18), 3159 (36), 3302 
(26), 3383 (27), 3408, 3632 (9), 4169, 4244 (4); Santos, V.J. 319 (29); Sarmento, A.C. 682 (16); Sartori, A.L.B. 279 (36); Sátiro, L.N. 30 (16); Sellow, F. s.n. B 1002430754 (27); Silva, B. 11 (17); Silva, N.T. 58357 (2); Silva, T.R.S. 202, 203 (25); Siqueira-Filho, J.A. 1892 (25); Smith, N.P. 60 (25); Sobral, M. 6756 (22); Soderstrom, T.R. 2120 (2); Sousa, L.A. 164 (25), 165 (29); Souza, E.B. 980 (16), 1385 (25); Souza, E.R. 60 (16); Souza, I.M. 40, 41, 42 (25), 65 (16), 78 (38), 96 (17), 101, 102 (16), 129 (17); Souza, V.C. 5225 (38), 5233,5234 (16); Souza-Silva, R.F. 72 (25); Stannard, B. 50844 (16), 51731 (30); Stradmann, M.T.S. 651 (16), 669 (38); Taylor, N.P. 1603 (25); Thomas, W.W. 9090 (18), 9181 (14), 9246 (10), 9322 (31), 10181 (18), 10188 (2), 10358 (4), 10459 (12), 10470 (18), 10863 (8), 11364 (28), 11375 (18), 11544, 11947 (2), 12274 (37), 12284 (29), 12297 (18), 12823, 12853 (25), 12885 (16), 13025 (18), 14061 (13), 14164 (27), 14166 (4), 14167 (18), 14206 (28), 14221 (18), 14222 (23), 14527 (18); Ule, E. 7122 (30); Valadão, R.M. 107 (16), 398 (4), 399 (14); van den Berg, C. 856 (32); Velloso H.P. 867 (4), 964 (9), 1015 (2), 1031 (4), 1037 (2), 1046, 1055, 1059 (4), 1064 R 41859 (14), 1064 a RB 554932 (36), 1089 (9), 1091, 1093, 1095, 1098, 1100, 1101 (4), 1103 (2), 1105, 1107, 1109, 1110 (4), 1111 R 41872 e RB 52189 (36), 1111 a RB 52184, 1117 (17), 1124 (36); Vieira, T.L. 2 (25); Walmor 288 (16); Wanderley, M.G.L. 955, 1503 (16), 1568 (38); Webster, G.L. 25734 (25); Wied-Neuwied, M. s.n. BR 517314, s.n. BR 517347, s.n. BR 517380 (9); Yoshida-Arns K. 610 (17); Zappi, D.C. 3378 (1), 3392 (13), 3406 (4); s/col., s.d. RB 248307 (30). 